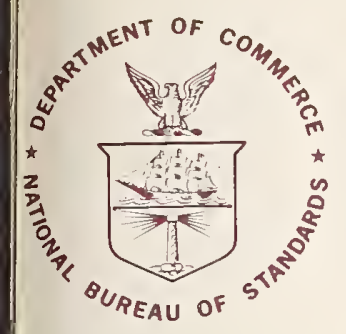

NBS TECHNICAL NOTE 909

U.S. DEPARTMENT OF COMMERCE / National Bureau of Standards

Investigation of Wind Damage in the Metropolitan Washington, D.C. Area, April 3-4, 1975

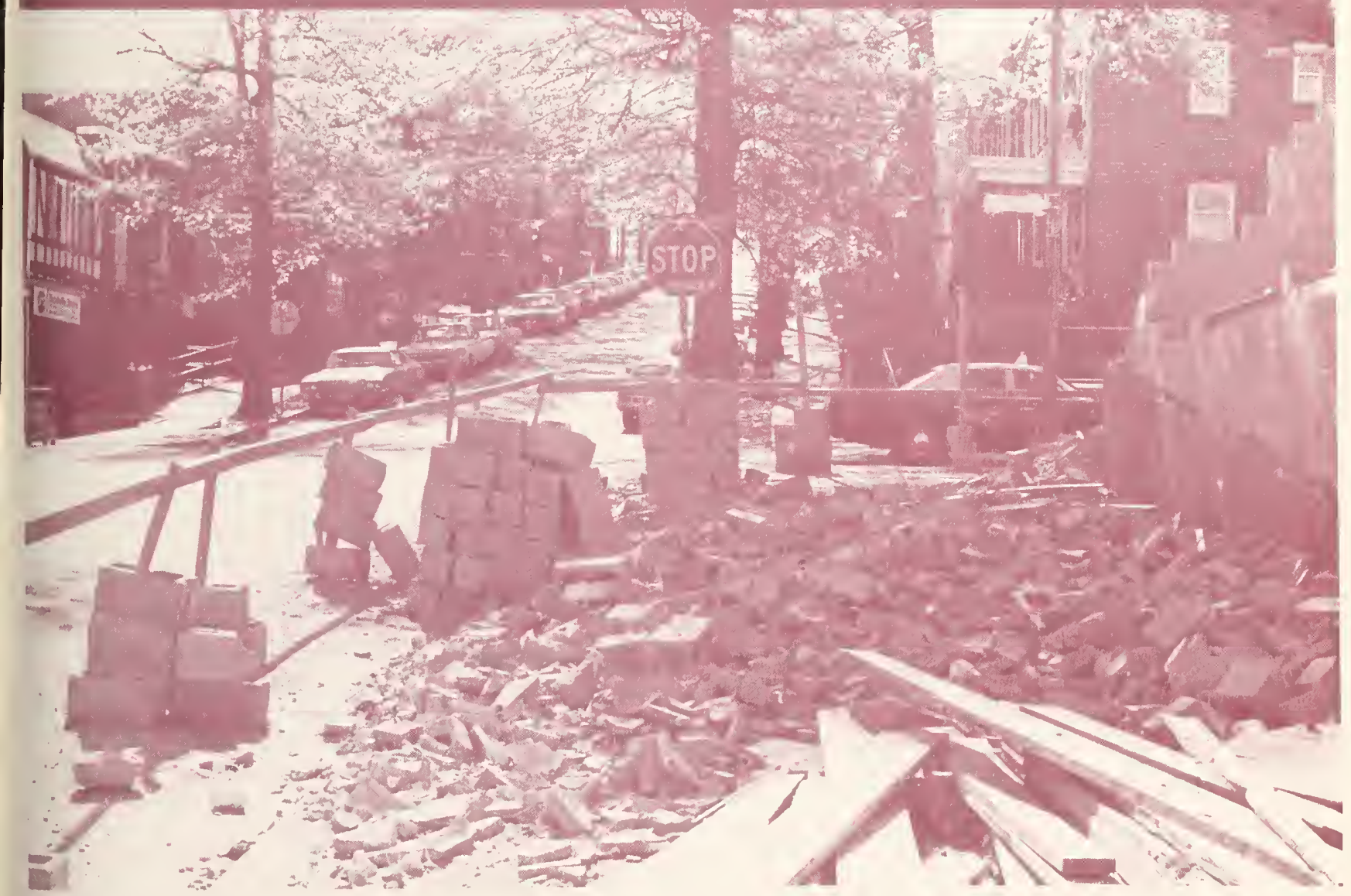


The National Bureau of Standards ${ }^{1}$ was established by an act of Congress March 3, 1901. The Bureau's overall goal is to strengthen and advance the Nation's science and technology and facilitate their effective application for public benefit. To this end, the Bureau conducts research and provides: (1) a basis for the Nation's physical measurement system, (2) scientific and technological services for industry and government, (3) a technical basis for equity in trade, and (4) technical services to promote public safety. The Bureau consists of the Institute for Basic Standards, the Institute for Materials Research, the Institute for Applied Technology, the Institute for Computer Sciences and Technology, and the Office for Information Programs.

THE INSTITUTE FOR BASIC STANDARDS provides the central basis within the United States of a complete and consistent system of physical measurement; coordinates that system with measurement systems of other nations; and furnishes essential services leading to accurate and uniform physical measurements throughout the Nation's scientific community, industry, and commerce. The Institute consists of the Office of Measurement Services, the Office of Radiation Measurement and the following Center and divisions:

Applied Mathematics - Electricity - Mechanics - Heat - Optical Physics - Center for Radiation Research: Nuclear Sciences; Applied Radiation - Laboratory Astrophysics ${ }^{2}$ - Cryogenics $^{2}$ - Electromagnetics ${ }^{2}$ — Time and Frequency ${ }^{2}$.

THE INSTITUTE FOR MATERIALS RESEARCH conducts materials research leading to improved methods of measurement, standards, and data on the properties of well-characterized materials needed by industry, commerce, educational institutions, and Government; provides advisory and research services to other Government agencies; and develops, produces, and distributes standard reference materials. The Institute consists of the Office of Standard Reference Materials, the Office of Air and Water Measurement, and the following divisions:

Analytical Chemistry - Polymers - Metallurgy — Inorganic Materials — Reactor Radiation - Physical Chemistry.

THE INSTITUTE FOR APPLIED TECHNOLOGY provides technical services to promote the use of available technology and to facilitate technological innovation in industry and Government; cooperates with public and private organizations leading to the development of technological standards (including mandatory safety standards). codes and methods of test; and provides technical advice and services to Government agencies upon request. The Institute consists of the following divisions and Centers:

Standards Application and Analysis - Electronic Technology - Center for Consumer Product Technology: Product Systems Analysis; Product Engineering — Center for Building Technology: Structures, Materials, and Life Safety; Building Environment; Technical Evaluation and Application - Center for Fire Research: Fire Science; Fire Safety Engineering.

THE INSTITUTE FOR COMPUTER SCIENCES AND TECHNOLOGY conducts research and provides technical services designed to aid Government agencies in improving cost effectiveness in the conduct of their programs through the selection, acquisition, and effective utilization of automatic data processing equipment; and serves as the principal focus within the executive branch for the development of Federal standards for automatic data processing equipment, techniques, and computer languages. The Institute consists of the following divisions:

Computer Services - Systems and Software - Computer Systems Engineering — Information Technology.

THE OFFICE FOR INFORMATION PROGRAMS promotes optimum dissemination and accessibility of scientific information generated within NBS and other agencies of the Federal Government; promotes the development of the National Standard Reference Data System and a system of information analysis centers dealing with the broader aspects of the National Measurement System; provides appropriate services to ensure that the NBS staff has optinum accessibility to the scientific information of the world. The Office consists of the following organizational units:

Office of Standard Reference Data - Office of Information Activities — Office of Technical Publications - Library - Office of International Relations - Office of International Standards.

\footnotetext{
1 Headquarters and Laboratories at Gaithersburg, Maryland, unless otherwise noted; mailing address Washington, D.C. 20234

${ }^{3}$ L.ocated at Boulder, Colorado 80302.
} 


\section{Investigation of Wind Damage in the Metropolitan Washington, D.C. Area, April 3-4, 1975}

F. Y. Yokel, C. W. Yancey,

L. E. Cattaneo, and R. D. Marshall

Center for Building Technology

Institute for Applied Technology

National Bureau of Standards

Washington, D.C. 20234

Sponsored by

Defense Civil Preparedness Agency

Department of Defense

Washington, D.C. 20301

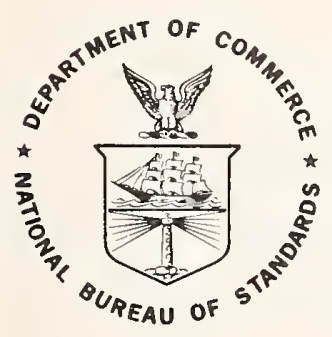

U.S. DEPARTMENT OF COMMERCE, Elliot L. Richardson, Secretary James A. Baker, III, Under Secrefary

Dr. Betsy Ancker-Johnson, Assistant Secrefary for Science and Technology NATIONAL BUREAU OF STANDARDS, Ernest Ambler, Acting Director Issued May 1976 


\section{Library of Congress Catalog Card Number: 76-600017}

National Bureau of Standards Technical Note 909

Nat. Bur. Stand. (U.S.), Tech. Note 909, 65 pages (May 1976)

CODEN: NBTNAE 
Page

Abstract and Key Words . . . . . . . . . . . . . . . 1

1. Introduction . . . . . . . . . . . . . . . . . 1

2. Meteorological Data. . . . . . . . . . . . . . . 2

2.1 Wind Speeds . . . . . . . . . . . . . . . 2

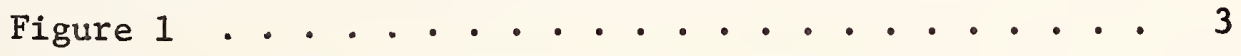

2.2 Comparison with Recommended Design Speeds . . . . . . 4

3. Method and Scope of Survey . . . . . . . . . . . . . 5

4. Fallure Histories. . . . . . . . . . . . . . . . 5

4.1 Masonry Wal1 Failure in a 19 Story Apartment Building . 5

Figures for Section 4.1 . . . . . . . . . . . . 8

4.2 Brick Veneer and Roof Failure in Wood Frame Buildings . 12

Figures for Section 4.2 . . . . . . . . . . . 14

4.3 Failure of a Brick Gable Wall and a Roof Overhang in a Three-Story Wood Frame - Brick Veneer Apartment Building. . . . . . . . . . . . . . 19

Figures for Section 4.3. . . . . . . . . . . 20

4.4 Dynamic Response of Concrete Masonry Infill Walls in

a Penthouse .. . . . . . . . . . . . 23

Figures for Section 4.4 . . . . . . . . . . . . 25

4.5 Roof Damage in a Three-Story Garden Apartíment Complex . 27

Figures for Section 4.5 . . . . . . . . . . 28

4.6 Failure of a Roof under Construction. . . . . . . . 33

Figures for Section 4.6 . . . . . . . . . . . 34

4.7 Collapse of Concrete Masonry Wa11s During Construction. 39

Figures for Section 4.7 . . . . . . . . . . 40

4.8 Miscellaneous Damage. . . . . . . . . . . . . . 44

Figures for Section 4.8 . . . . . . . . . . . 45

5. Discussion of Field observations . . . . . . . . . . . . 54

5.1 General . . . . . . . . . . . . . . . . . 54

5.2 Non-Loadbearing Masonry Walls . . . . . . . . . . . 54

5.3 Overhanging Roofs . . . . . . . . . . . . . 56

5.4 Unusual Building Configurations . . . . . . . . . . . 56

5.5 Structural Skin (cladding and roofing). . . . . . . 57 
5.6 Buildings under Construction. . . . . . . . . . . 57

6. Summary and Recommendations. . . . . . . . . . . . . . 58

7. Acknowledgements . . . . . . . . . . . . . . . 59

8. References . . . . . . . . . . . . . . . 60 
Investigation of Wind Damage in the

Metropolitan Washington, D.C. Area, April 3-4, 1976

F.Y. Yoke1, C.W. Yancey, L。E. Cattaneo, and R.D. Marshal1

A limited investigation was conducted of wind damage that occurred on April 3 and 4, 1975 in the Metropolitan Washington, D.C. area. Meteorological data indicate that the winds were somewhat less severe than those that should be anticipated by designers. Thus, most of the observed damage reflects inadequacies in design or construction. Damage was observed in occupied buildings, as well as in buildings under construction. Damaged elements of occupied buildings included: masonry curtain walls; masonry gable walls; masonry veneer; roofs with overhangs; roofing; and cladding. Damaged elements of buildings under construction included roofs and masonry walls.

Key Words: Building codes; design standards; masonry construction; roofs; siding; structural engineering; wind; wind damage; wind engineering.

\section{INTRODUCTION}

On April 3 and 4, 1975, during a period of approximately 36 hours, a large region in the Eastern United States was subjected to severe winds. The area affected extended from Northern Pennsylvania to Southern Virginia. The National Bureau of Standards conducted a limited study of wind damage to buildings in, and adjacent to, the Metropolitan Washington, D.C. area. The information presented in this documentation and interpretation of the observed damage is intended to serve as a reference for further studies, research and recommendations. 


\section{METEOROLOGICAL DATA}

\subsection{Wind Speeds}

Continuous records of wind speeds for the period April 3-4 were obtained by the National Weather Service at stations located at Washington National Airport, directly across the Potomac River from the District of Columbia, and at Dulles International Airport, approximately 21 miles $(34 \mathrm{~km})$ to the west. Both anemometers have typical airport exposures and are located 20 feet $(6.1 \mathrm{~m})$ above ground level. The locations of the observation points are shown in figure 1.

The record at Washington National Airport shows a fairly steady increase in sustained wind speed (1-minute average) from 10 knots $(\mathrm{kts}) \stackrel{1 /}{ }(5.1 \mathrm{~m} / \mathrm{s})$ at $0400 \mathrm{hrs}(4 \mathrm{A.M}$.$) to 30 \mathrm{kts}(15.4 \mathrm{~m} / \mathrm{s})$ at 1200 hrs on April 3. Peak gusts (2-3 second average) ranged from $25 \mathrm{kts}$ $(12.9 \mathrm{~m} / \mathrm{s})$ at $0500 \mathrm{hrs}$ to $53 \mathrm{kts}(27.3 \mathrm{~m} / \mathrm{s})$ at $1200 \mathrm{hrs}$. Several gusts in excess of $50 \mathrm{kts}(25.7 \mathrm{~m} / \mathrm{s})$ were observed during the remainder of the day with the maximum of $57 \mathrm{kts}(29.3 \mathrm{~m} / \mathrm{s})$ observed at 1549 hrs when the wind direction was 310 degrees. The record for April 4 indicates sustained wind speeds of 20 to $30 \mathrm{kts}(10.3$ to $15.4 \mathrm{~m} / \mathrm{s})$ with peak gusts ranging from 30 to $50 \mathrm{kts}(15.4$ to $25.7 \mathrm{~m} / \mathrm{s}$ ) throughout the day. The maximum speed of $53 \mathrm{kts}(27.3 \mathrm{~m} / \mathrm{s})$ occurred at 1247 hrs. The wind direction ranged from 280 to 350 degrees.

The records obtained at Dulles International Airport on April 3 and 4 are quite similar to those described above, the maximum gusts being slightly less. The peak recorded gust on April 3 was 54 kts $(27.8 \mathrm{~m} / \mathrm{s}$ ) from 290 degrees at $1953 \mathrm{hrs}$ and the peak for April 4 was $45 \mathrm{kts}(23.1 \mathrm{~m} / \mathrm{s})$ from 300 degrees at $0816 \mathrm{hrs}$.

Most of the damage in the Washington, D. C. metropolitan area is believed to have occurred on April 3 between 1200 and 1900 hrs. The approximate wind direction at Washington National Airport during this interval was 310 degrees and several gusts in excess of $50 \mathrm{kts}$ $(25.7 \mathrm{~m} / \mathrm{s})$ were recorded.

As with similar storms, wind speeds far exceeding these quoted above were reported, but could not be verified. A typical example

I/ Meteorological data were reported in nautical miles per hour (kts). 


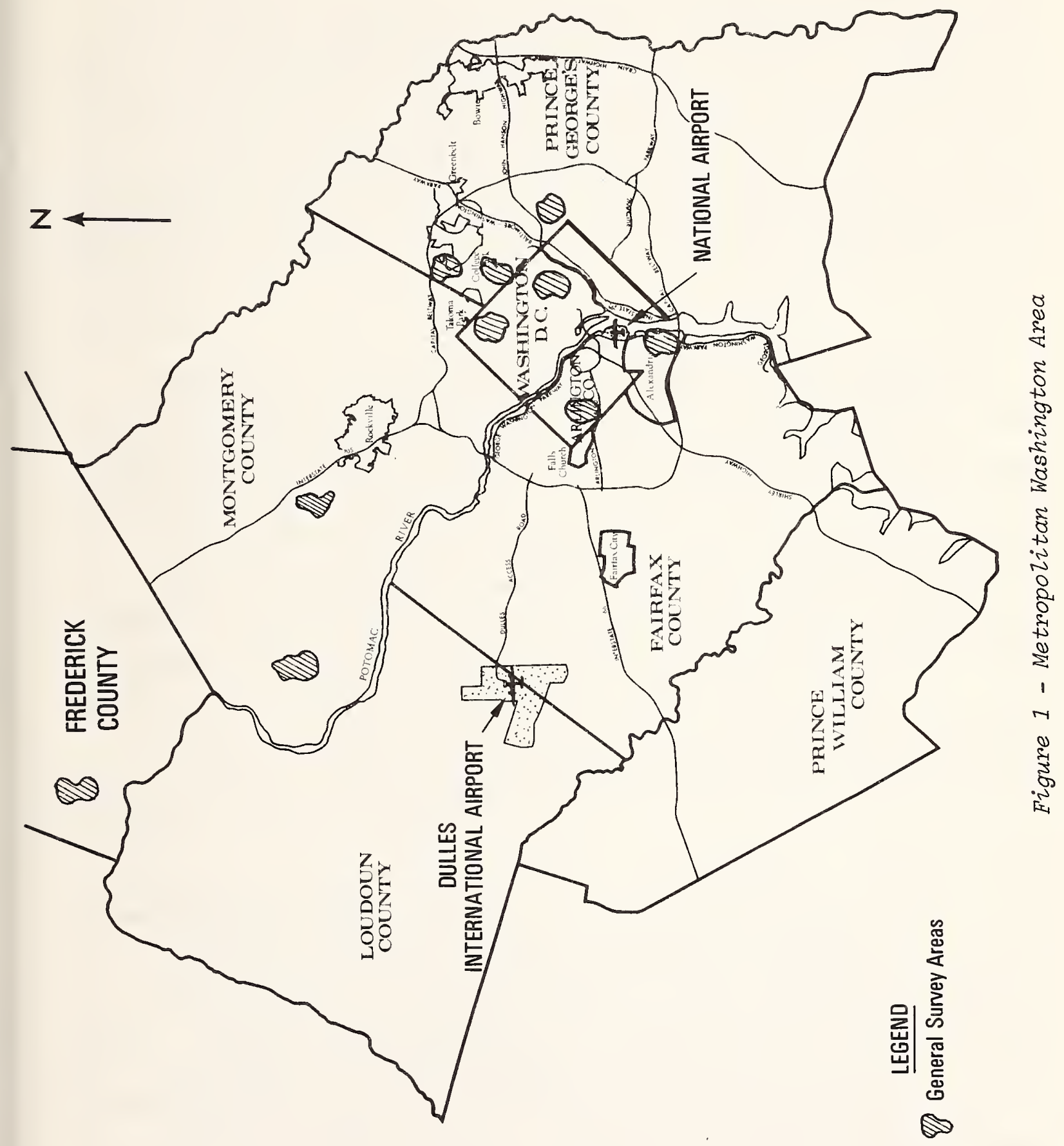


is a reported speed in excess of $100 \mathrm{mph}(44.7 \mathrm{~m} / \mathrm{s})$ in Prince Georges County, Maryland. A subsequent inquiry of the source of the information revealed that the anemometer indicator in question had a double scale with ranges of $0-25$ and $0-100 \mathrm{mph}$. The scale selection switch was set on the low range, thus indicating $100 \mathrm{mph}$ to a person not familiar with the device. It is quite likely that wind speeds in the area extending from Frederick, Maryland north to Pennsylvania were higher than the Washington National Airport observations due to valley channeling or mountain lee wave effects.

\subsection{Comparison with Recommended Design Speeds}

In assessing the performance of buildings subjected to extreme winds, it is necessary to compare the probable maximum speeds with those which serve as a basis for the calculation of design wind loads. For this purpose the record obtained at Washington National Airport seems most appropriate since the exposure, while locally open, has a long fetch extending over the Falls Church and Arlington, Virginia area. The basic wind speed used in American National Standard (ANSI) A58.1 $1972[1]^{2 /}$ is the annual extreme fastest mile speed at 30 feet $(9.1 \mathrm{~m})$ above ground for a given mean recurrence interval. The associated terrain is flat, open country. Using the $1 / 7$ power law, the peak gust at 30 feet $(9.1 \mathrm{~m})$ for Washington National Airport on April 3 was $70 \mathrm{mph}$ $(31.3 \mathrm{~m} / \mathrm{s})$ which corresponds to a fastest-mile speed of approximately $56 \mathrm{mph}(25 \mathrm{~m} / \mathrm{s})$. Comparing this with the recommended basic wind speeds for the Metropolitan Washington, D. C. area (ANSI A58.1), the associated mean recurrence interval is roughly 5 years. It seems reasonable to conclude, therefore, that the winds of April 3-4, 1975 were not unusually severe from the viewpoint of recommended design speeds. It is interesting to note that the recommended basic wind speed for a 50-year mean recurrence interval is $75 \mathrm{mph}(33.5 \mathrm{~m} / \mathrm{s}$ ) (ANSI A58.1) which results in dynamic pressures some 80 percent higher than those associated with the observed fastest-mile speed.

2/ Numbers in brackets indicate references listed in Section 7. 


\section{METHOD AND SCOPE OF SURVEY}

A survey of limited scope was conducted. Thus no attempt was made to determine the ratio between the number of buildings damaged and the total inventory of buildings in the affected area. There was also no attempt to secure plans and specifications for the buildings surveyed or to conduct an in-depth engineering analysis in order to determine the causes of failure or to verify assumed failure mechanisms. The survey was generally limited to visual observation of distress in the field and to conversations with building occupants, construction personnel and building officials.

At the outset, building inspectors' offices in the various jurisdictions in the Washington, D. C. metropolitan area were contacted in order to locate the more important cases of damage to buildings. Cooperation was subsequently received from building officials in gaining access to damaged buildings.

In each case an attempt was made to document a11 known structural damage by visual inspection. In some cases repair work was already under way at the time of the survey team's arrival, and, as a consequence, some $\Omega$ ? the damage that had occurred was difficult to assess.

The survey included occupied buildings and buildings under construction. The general areas where building damage was surveyed are indicated in figure 1. (hatched areas).

\section{FAILURE HISTORIES}

\subsection{Masonry Wall Failure in a 19 Story Apartment Building}

Figure 2 shows the rear elevation of a 19 story apartment building complex. The prevailing wind direction is shown by the arrow at the top of the figure. In this building a masonry wall fell from the location marked 1 into a lobby (location 2) destroying the roof of the lobby. Some of the debris from the wall and the lobby roof resting on the floor of the lobby is shown in figure 3 . Figure 4 shows the wall failure in more detail and figure 5 shows an elevation of a similar wall in the opposite wing of the twin buildings which did not fall. The buildings are reinforced concrete structures. 
Typically, reinforced concrete flat slabs, marked number 1 in figure 4, are structurally supported by reinforced concrete bearing walls marked number 2 in figure 4. The roof slab, marked number 3 in figure 4 is a reinforced concrete slab which is also supported by the concrete walls and is further stiffened by a reinforced concrete rim beam, marked number 1 in figure 5. The masonry walls are nonstructural curtain walls consisting of one wythe of brick backed up by one wythe of nominally 4 in $(10 \mathrm{~cm})$ thick concrete block. Ties between the brick wythe and the concrete block wythe are provided by truss-type horizontal joint reinforcement. There is no vertical reinforcement and the field inspection showed no evidence that reinforcement ties were provided between the masonry wall and the roof or between the masonry wall and the floor slabs. Based on the visual inspection and on occupant accounts the failure mechanism is envisioned as follows: First the window, marked number 4 in figure 4 (see the encircled area on the right hand building) broke inward under the wind pressure, the local wind direction being substantially diffexent from the prevailing direction. Subsequently, outward pressure acted on all the interior surfaces of the room (the opposite window in the same room did not break) and the accelerated flow between the buildings probably resulted in very low pressures acting on the exterior of the wall. In addition to this outward pressure, the roof was quite likely subject to upward pressure on the overhanging part and to suction on the top. The combination of these pressures together with the probable absence of ties between the wall and the roof caused the masonry wall to fail as a cantilever along the top of the floor slab of the uppermost story. Figure 6 shows a portion of the failure surface. It should be noted that the failure surface (near the edge of the floor slab) is clean and smooth with no substantial remnants of the mortar joint above it. This is taken as an indication that the bond between the mortar joint of the concrete block wythe and the floor slab was probably weak. Thus at this cross section, effective moment resistance was provided only by one 3-1/2 in $(8.9 \mathrm{~cm})$ wide brick wythe. There was not enough moment resistance available to prevent the wall from failing as a cantilever beam. The weight of the wall section that fell on 
the lobby was considerable and could have caused loss of life. A view from underneath the roof slab is shown in figure 7 . Note the concrete rim beam which stiffens the roof slab. The surface where the wall separated is marked by an arrow. It can be reasonably assumed that most of the weight of this portion of the roof slab is transferred by the rim beam to the concrete columns and therefore only a minor part of this weight rests on the masonry wall. Thus no substantial frictional force would resist the outward movement of the top of the masonry wall. Other views of the failure are provided in figures 8 and 9. 


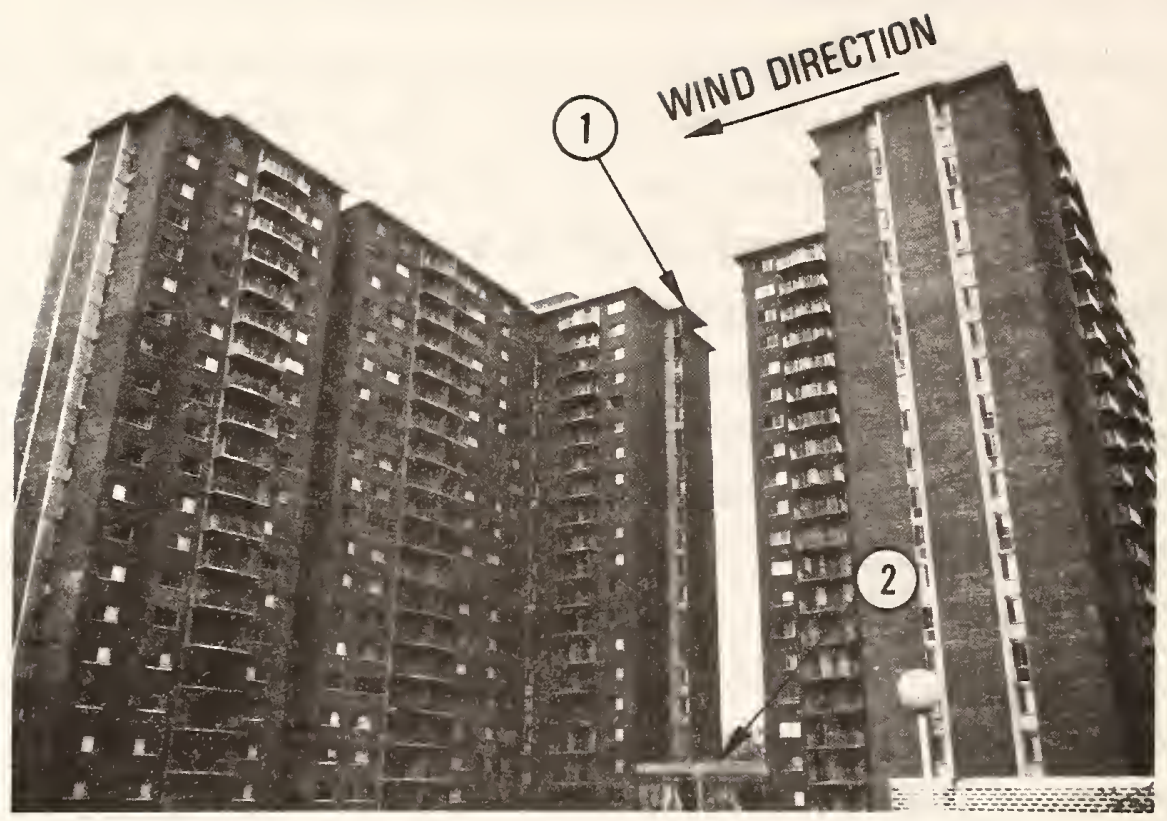

Figure 2 - Damaged areas of high-rise apartment building. Looking south.

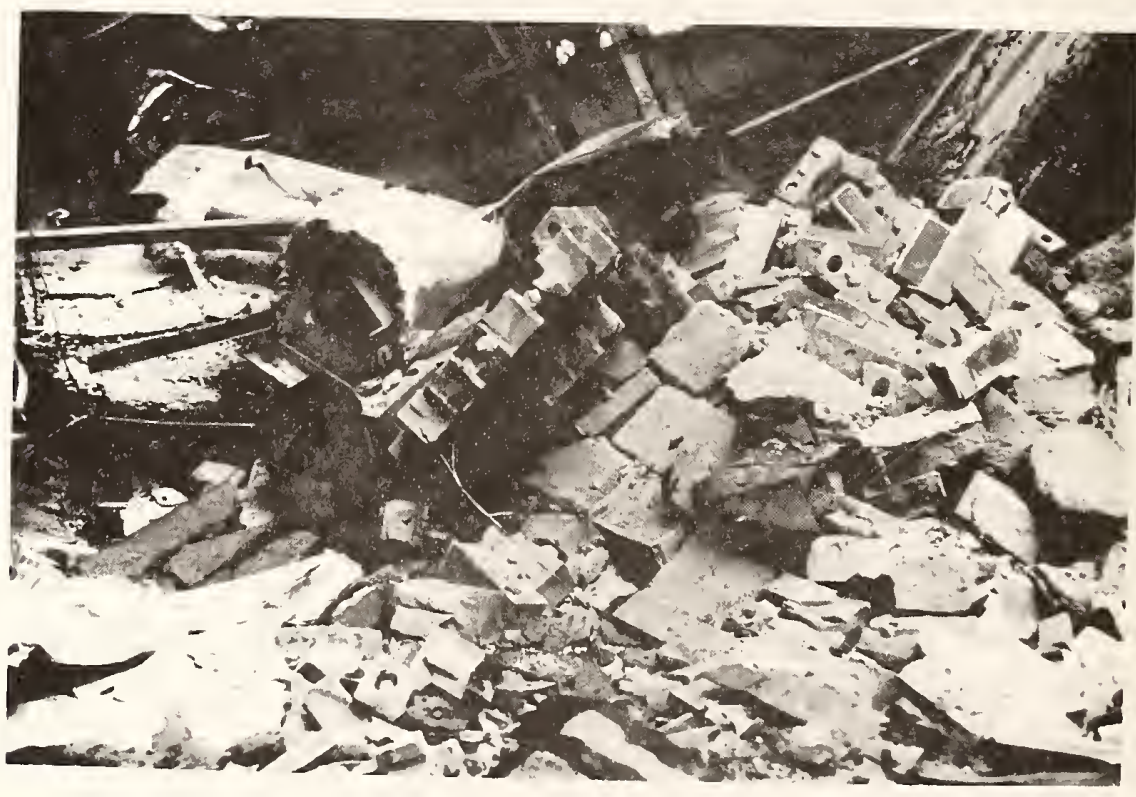

Figure 3 - Partial view of the debris on the floor of the lobby. 


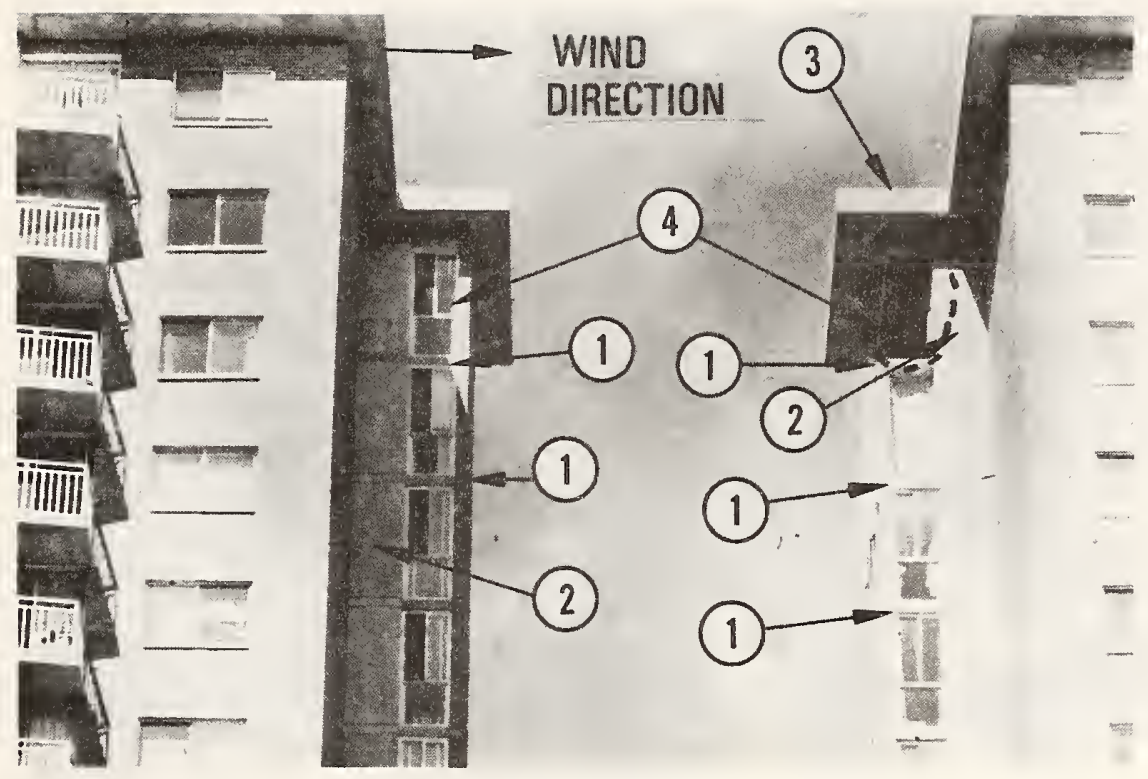

Figure 4-Structural details of the twin buildings. Looking north.

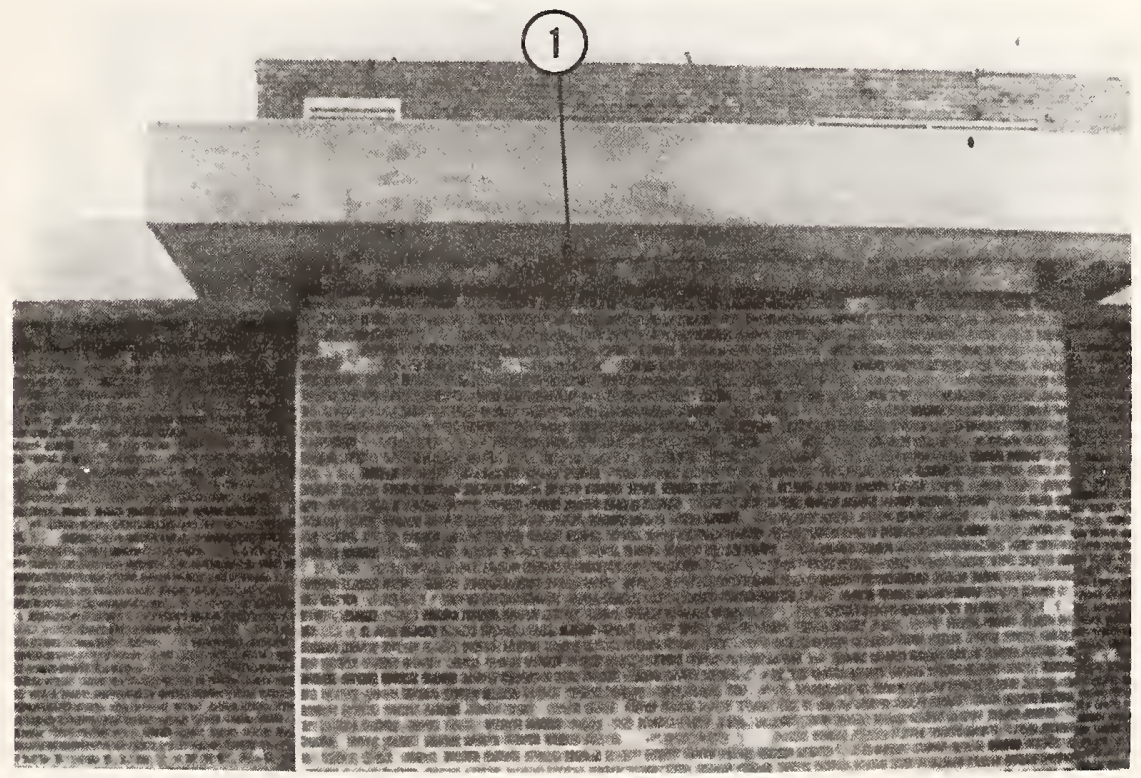

Figure 5 - Front elevation of similar wall located in undamaged building. Looking west. 


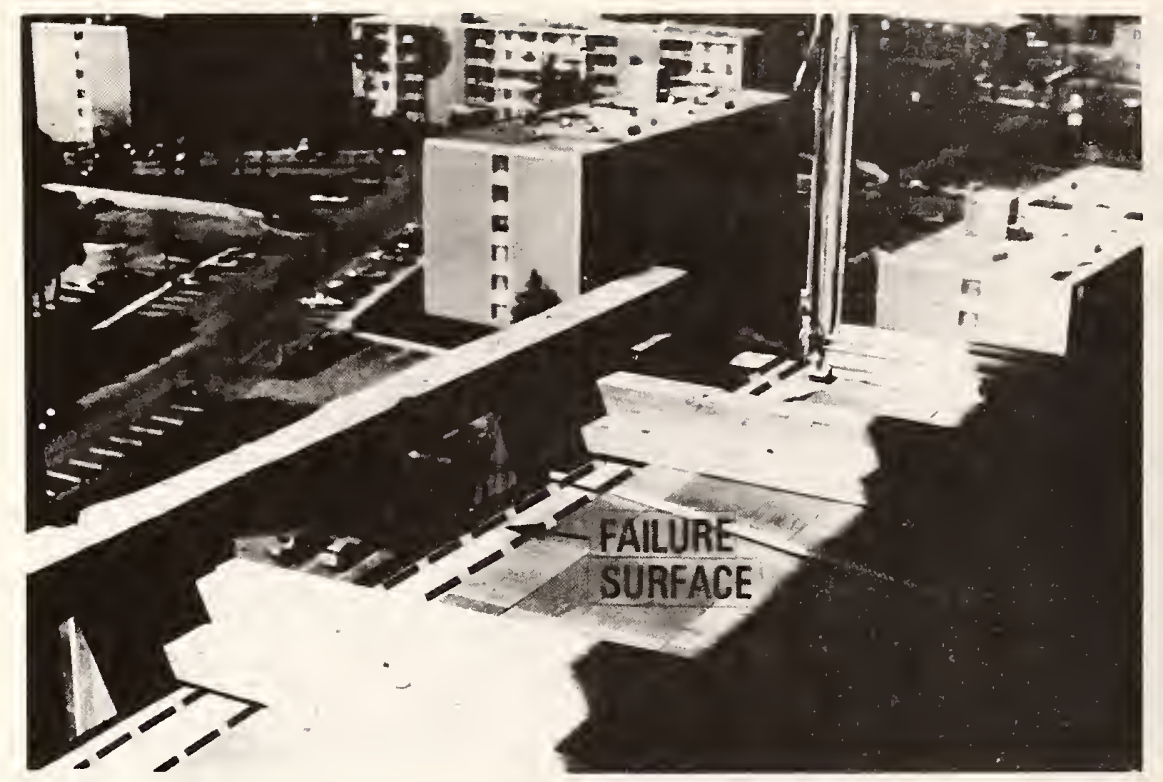

Figure 6 - Failure surface (between dashed lines) on top of floor slab.

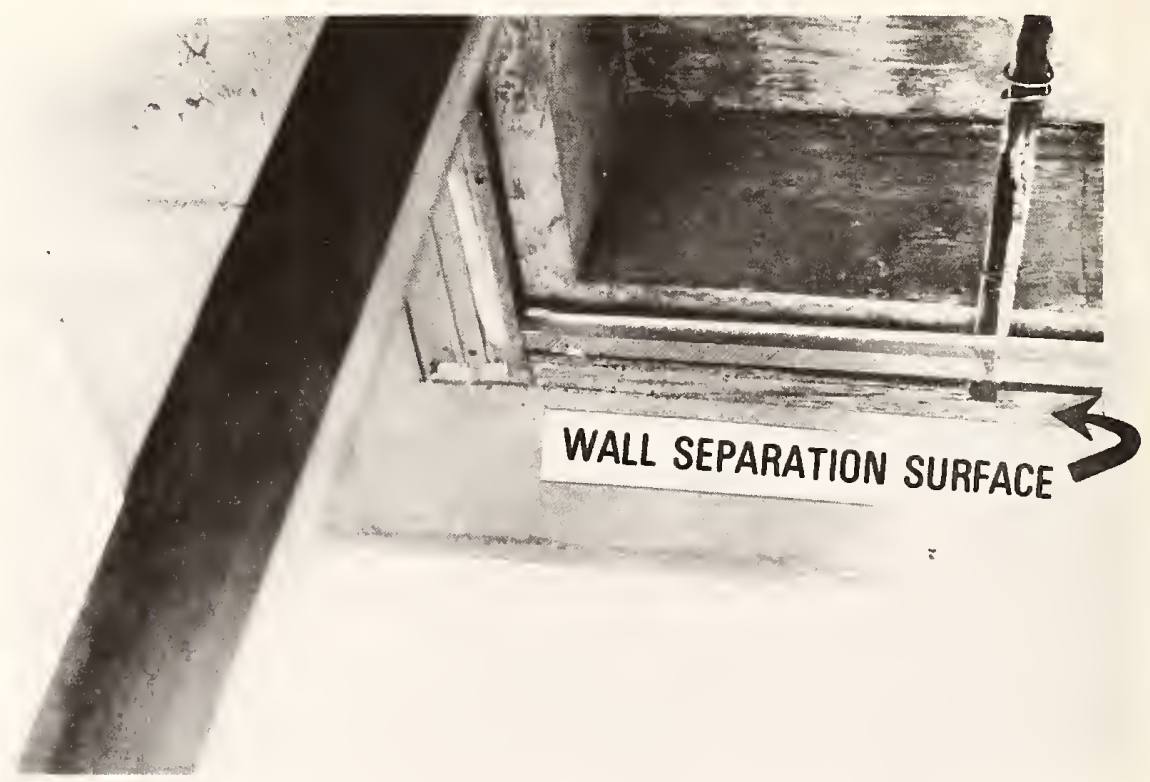

Figure 7 - Surface of separation between rim beam and top of wall. Looking at underside of roof slab. 


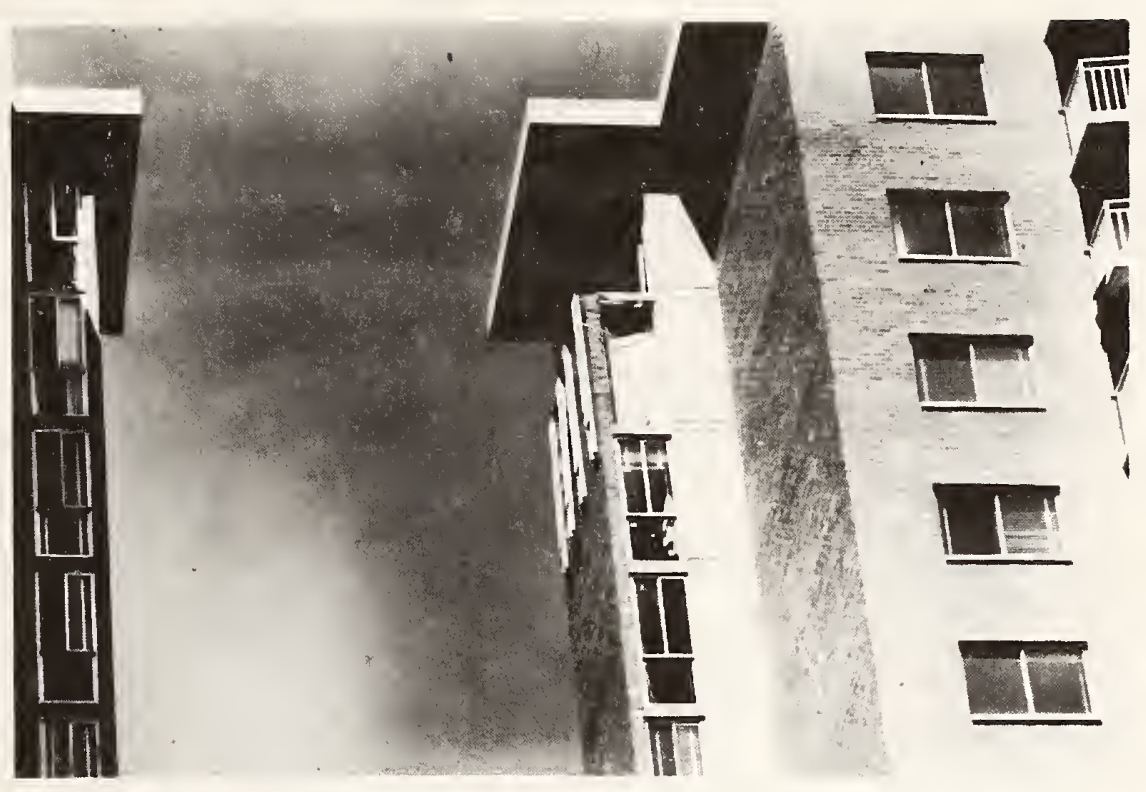

igure 8 - View of upper-story domage. Looking north.

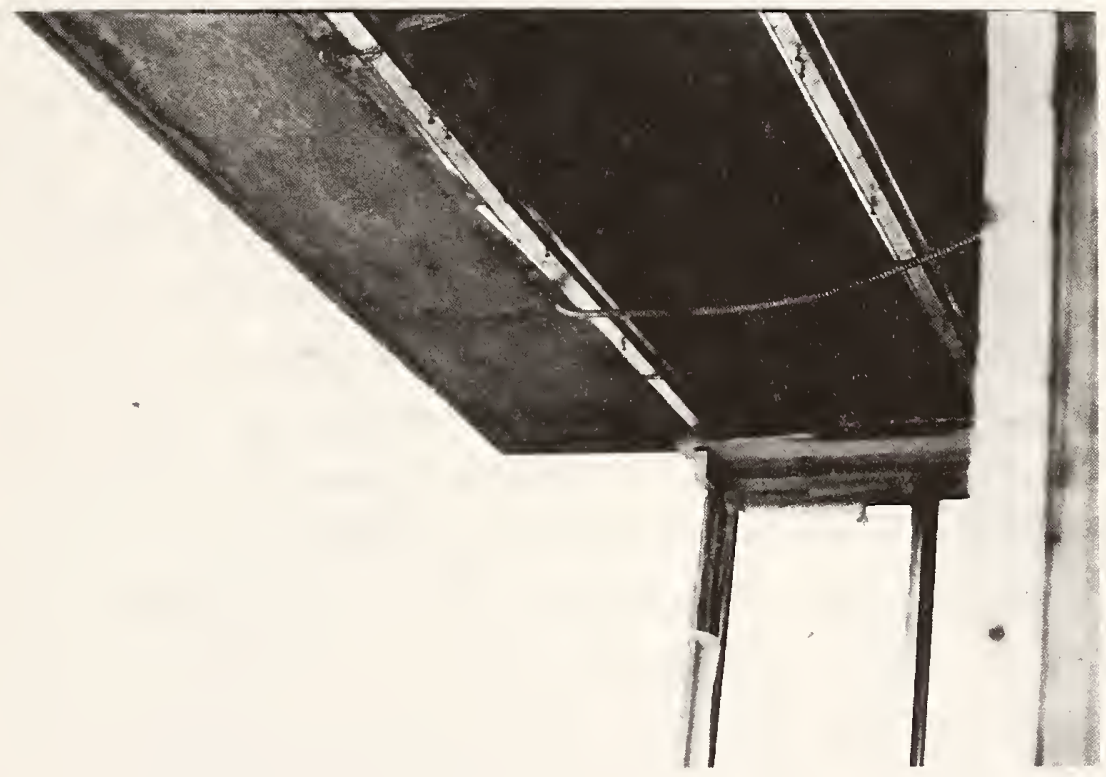

Figure 9 - Closeup of roof slab in damaged area. Looking north. 


\subsection{Brick Veneer and Roof Failure in Wood Frame Buildings}

Figure 10 is a rooftop view which shows a portion of a garden apartment complex consisting of two and three-story, wood-frame, brick veneer structures. The end walls of three buildings in this complex were damaged as a result of the brick veneer flexing and separating from the sheathing and wood framing. Figure 11 shows the most severe of the three cases of endwall damage. The brick veneer failed over a large area of the wall. Eyewitnesses reported a transverse deflection of approximately 6 to 8 inches (15 to $20 \mathrm{~cm}$ ) in the brick veneer before the failure occurred. The walls in the other two similarly affected buildings were shored (or braced) before substantial flexural failure of the veneer occurred. The prevailing wind direction is shown by the arrow in figure 11. The brick veneer was connected to the wood framing by corrugated steel ties. Evidence of broken ties as well as of the ties which were pulled out from the wood construction was found in the field investigation.

The wind direction, which was parallel to the wall, probably caused suction to act on the brick veneer. Two possible failure mechanism are envisioned: 1 . the outward deflection of the gable wall could have exceeded the deflection tolerance of the masonry veneer; 2. the ties could have been too weak or too flexible to prevent a separation between the masonry veneer and the wood framing. The location of the failure area relative to the floor diaphragms which restrain the outward deflection of the wood framing seems to indicate that the failure in this case was caused by separation between the masonry veneer and the wood framing. There also seems to be evidence that the brick veneer could have moved substantially outward before the ties between the brick veneer and the wood framing were actually structurally engaged. This is illustrated by figure 12, which shows a tie connected to a brick taken from the site. The only nail hole in that tie through which a nail was driven is shown by the arrow. The distance of this nail hole from the back face of the brick indicates that the brick could have moved outward substantially before the tie was tight enough to be structurally engaged. Figure 13 shows one of two endwalls which was braced because it was flexing excessively. A total failure 
of the veneer was prevented by the bracing. The two arrows show the distance between the present location of the window and its original location relative to the veneer (identified by the remnants of the caulking). Note that the wall moved out considerably. The deflection seen in the picture is actually the residual deflection that remained after bracing. The maximum deflection during the wind storm probably substantially exceeded the deflection seen here. Figure 14 shows the second wall which had to be braced during the storm. It is evident that the strength or stiffness deficiency in the veneer construction was not limited to the building where complete veneer failure occurred.

Some of the roof damage in the same apartment complex is shown in figure 15. It occurred mostly near the windward edges of the roofs. It should be noted that not only were roof shingles ripped out, but also, in some instances, the supporting plywood sheets failed. Failure of the plywood sheets tended to occur at the overhanging parts of the roofs. Figure 16 shows a damaged roof under repair. The original projecting purlins which faced the direction of the wind were ripped out and had to be replaced. A measure taken to strengthen the new projecting purlins is shown in figure 17; the timber cleat identified by the arrow was added and nailed to the truss and the projecting purlin respectively. In this manner resistance against uplift pressure was provided. 


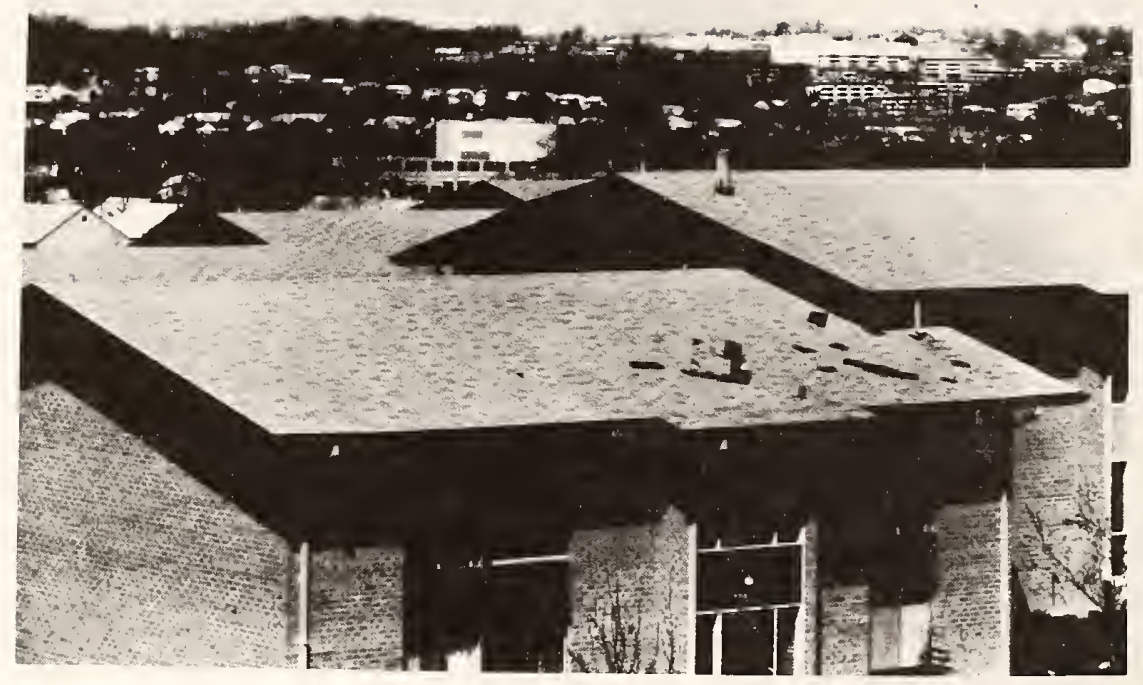

Figure 10 - Rooftop view of garden apartments domaged by wind. Looking northwest.

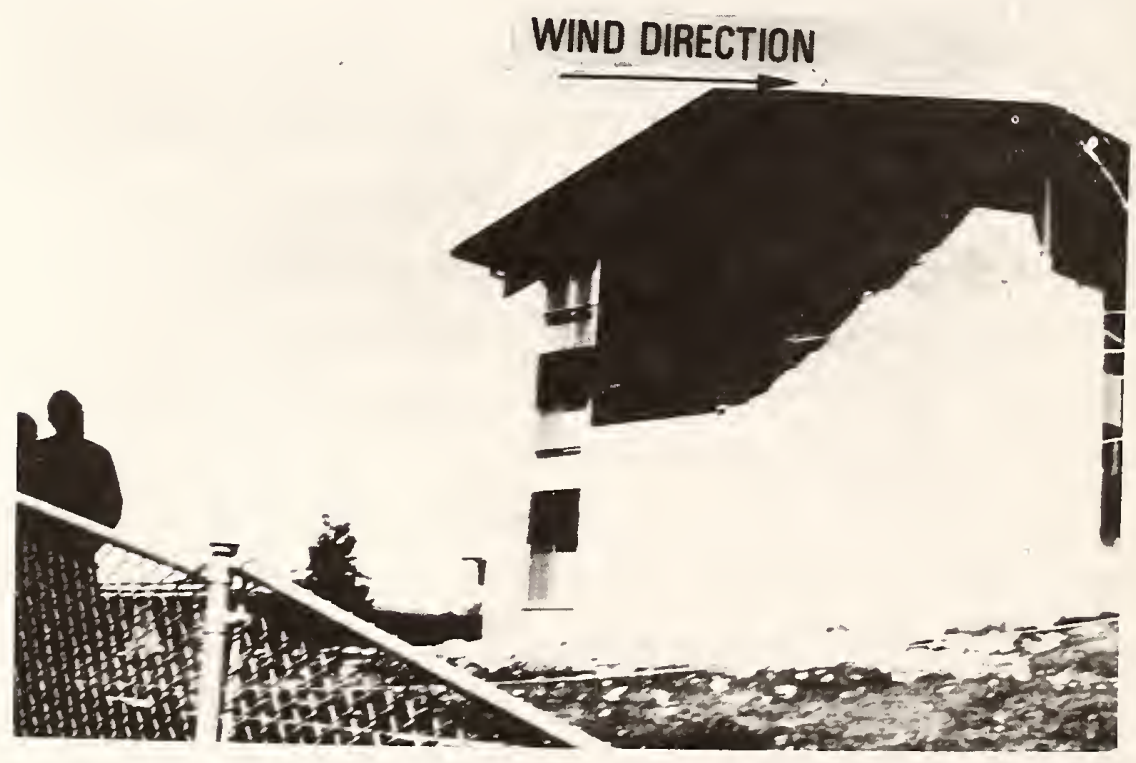

Figure 11 - Damaged brick veneer endwall in a 3-story building. Looking north. 

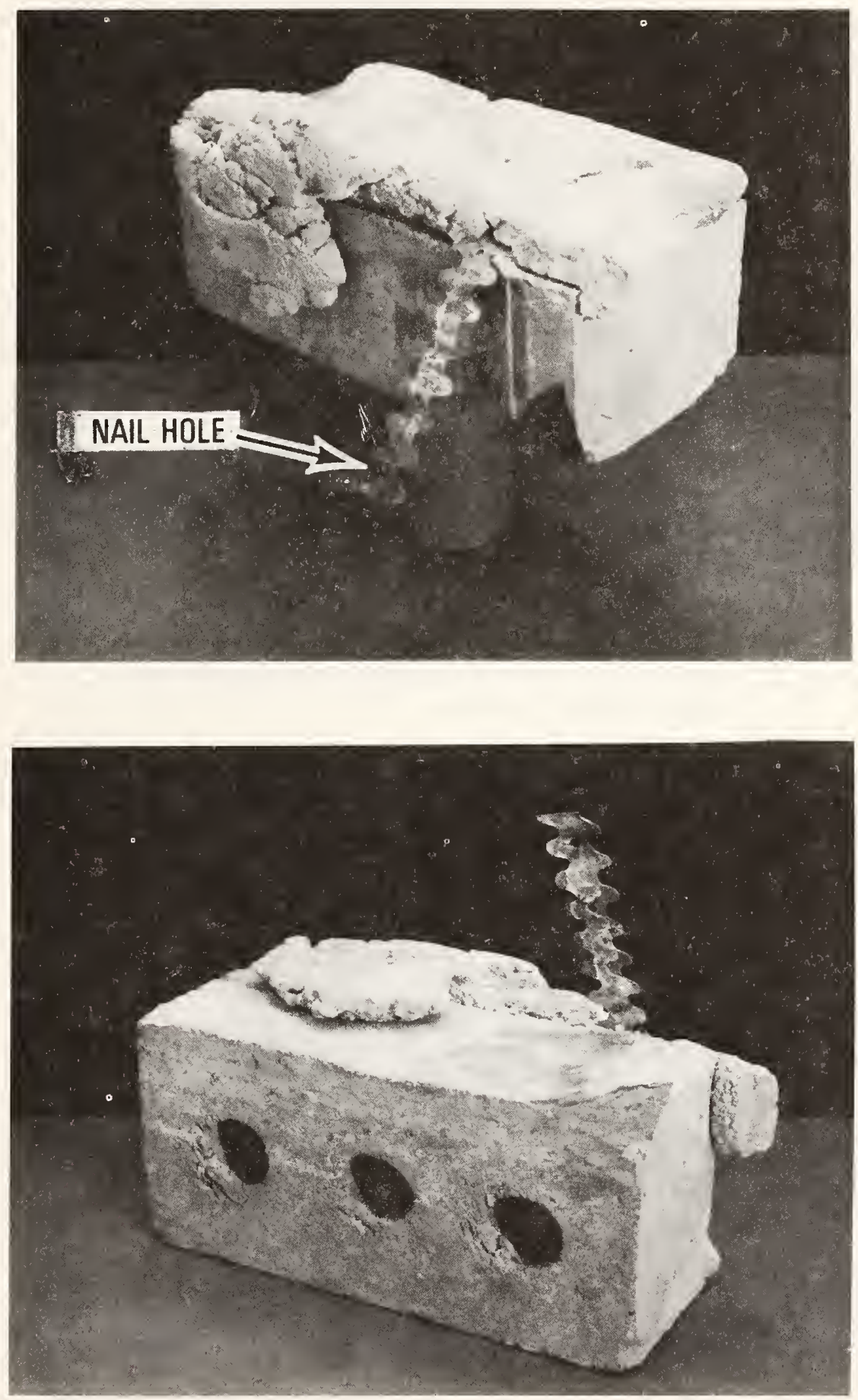

Figure 12 - Two views of a brick and connected tie taken from the endwalz debris. 

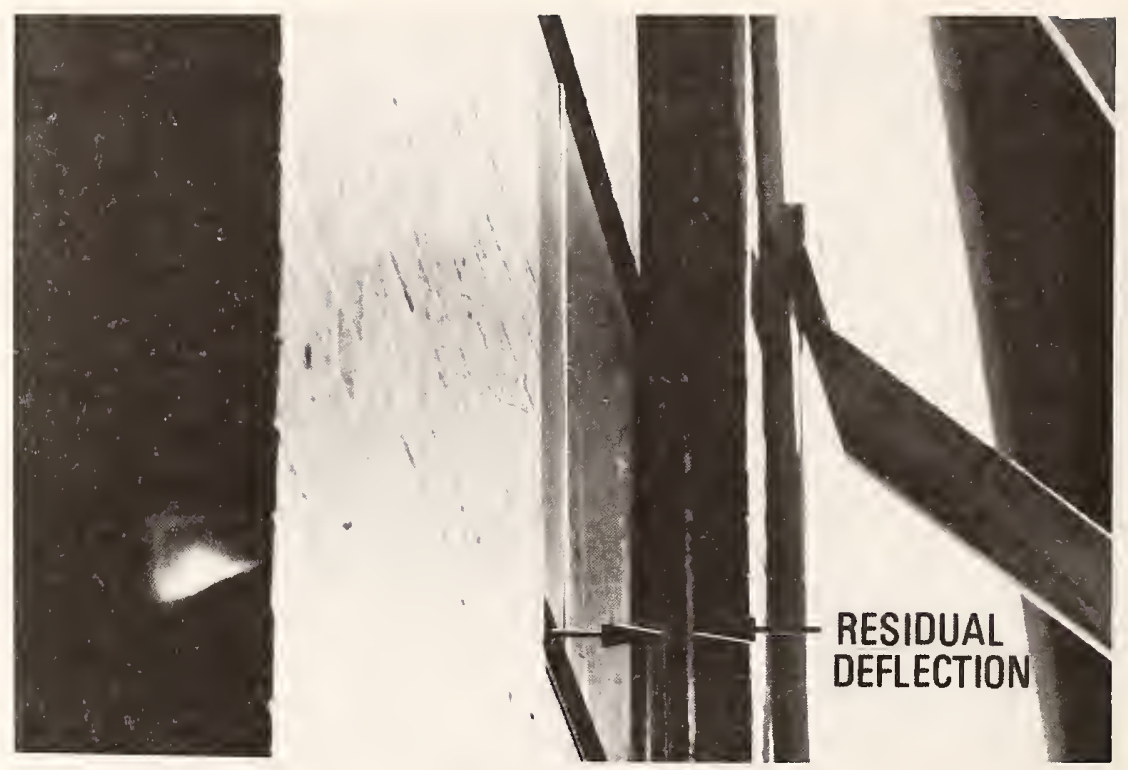

Figure 13 - A brick veneer endwall braced because of excessive flexing.

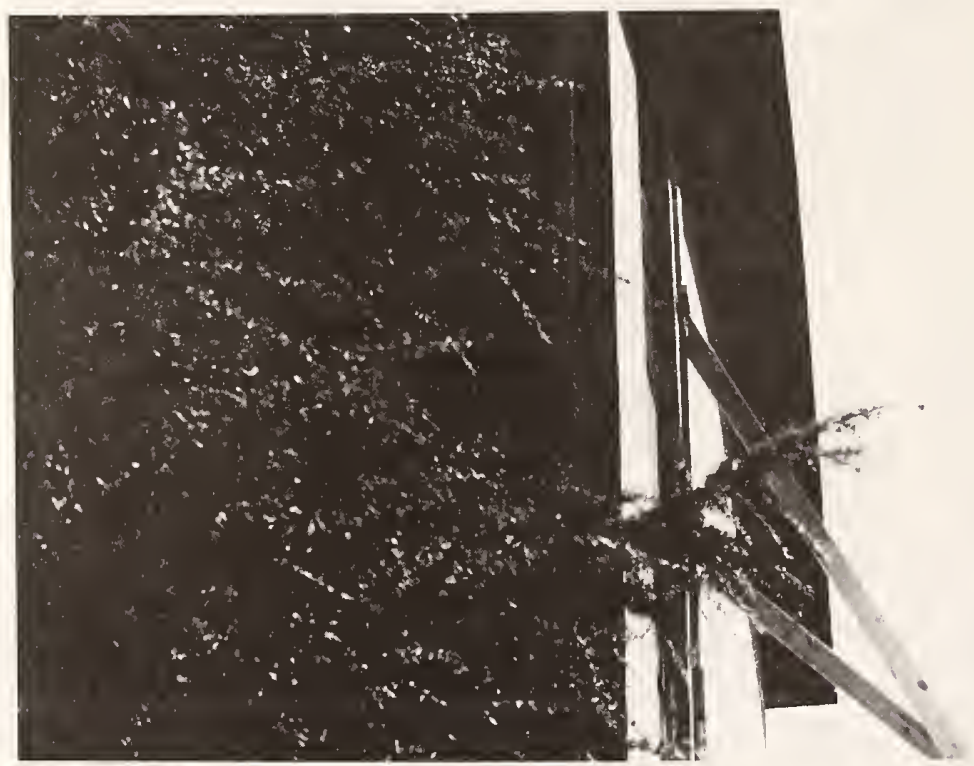

Figure 14 - A second endwall braced because of excessive flexing. 


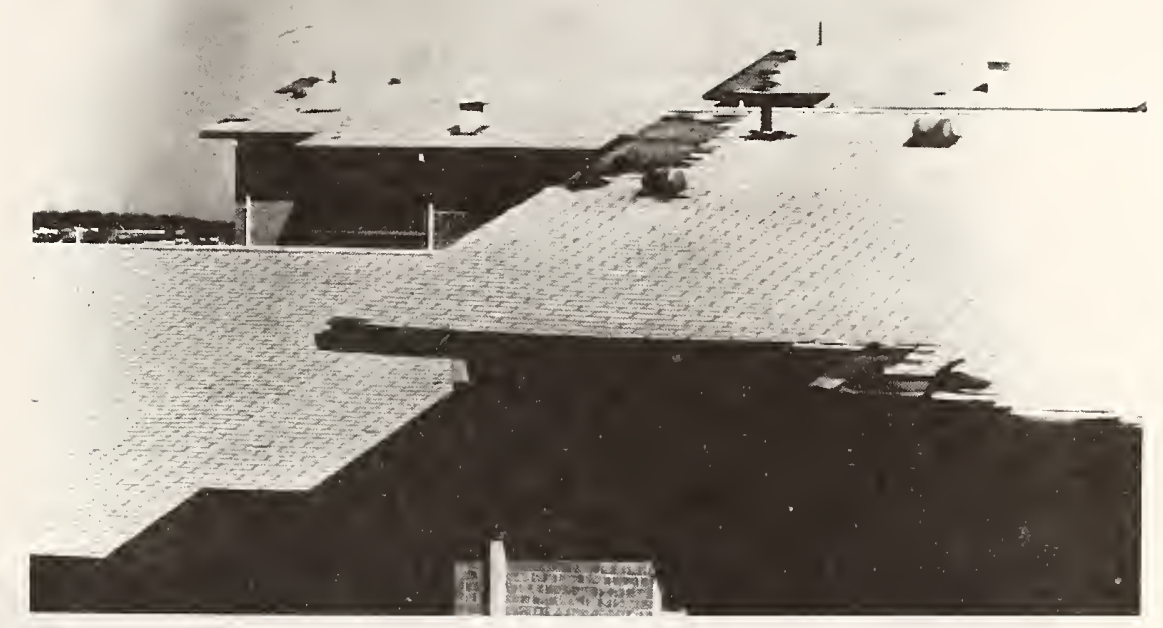

Figure 15 - Typical roof damage occurring along the windward edges. Looking north.

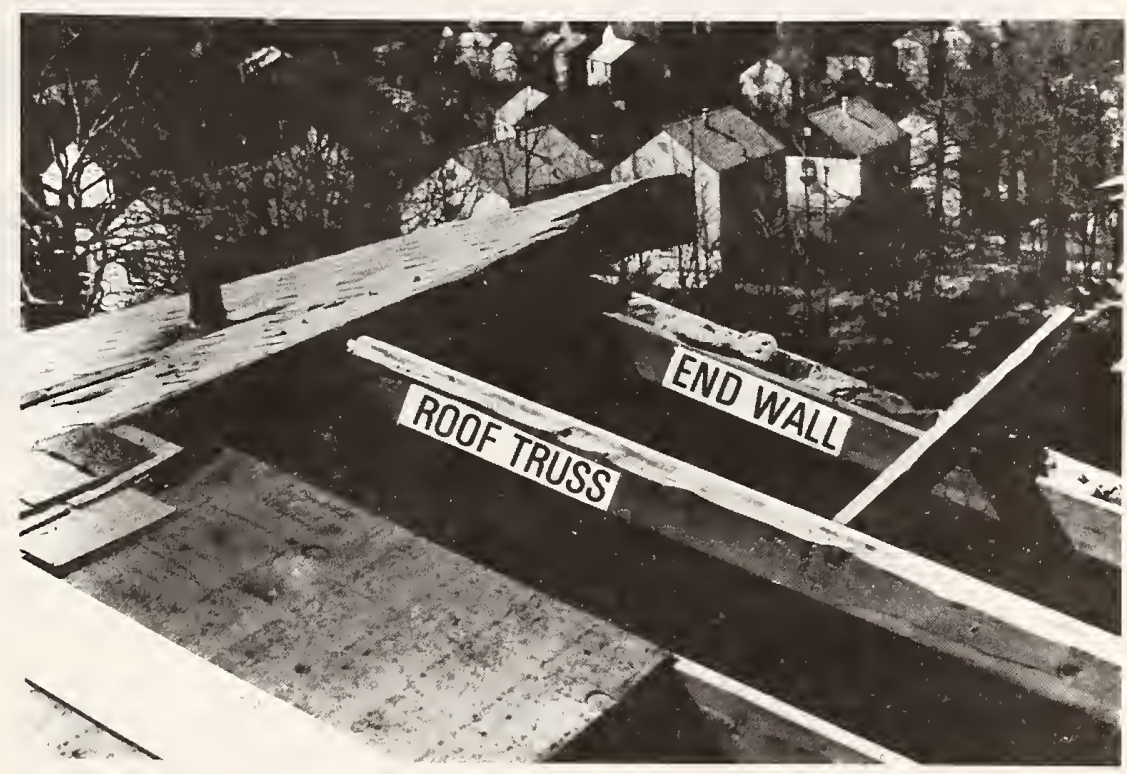

Figure 16 - Partial view of a damaged roof under repair. 


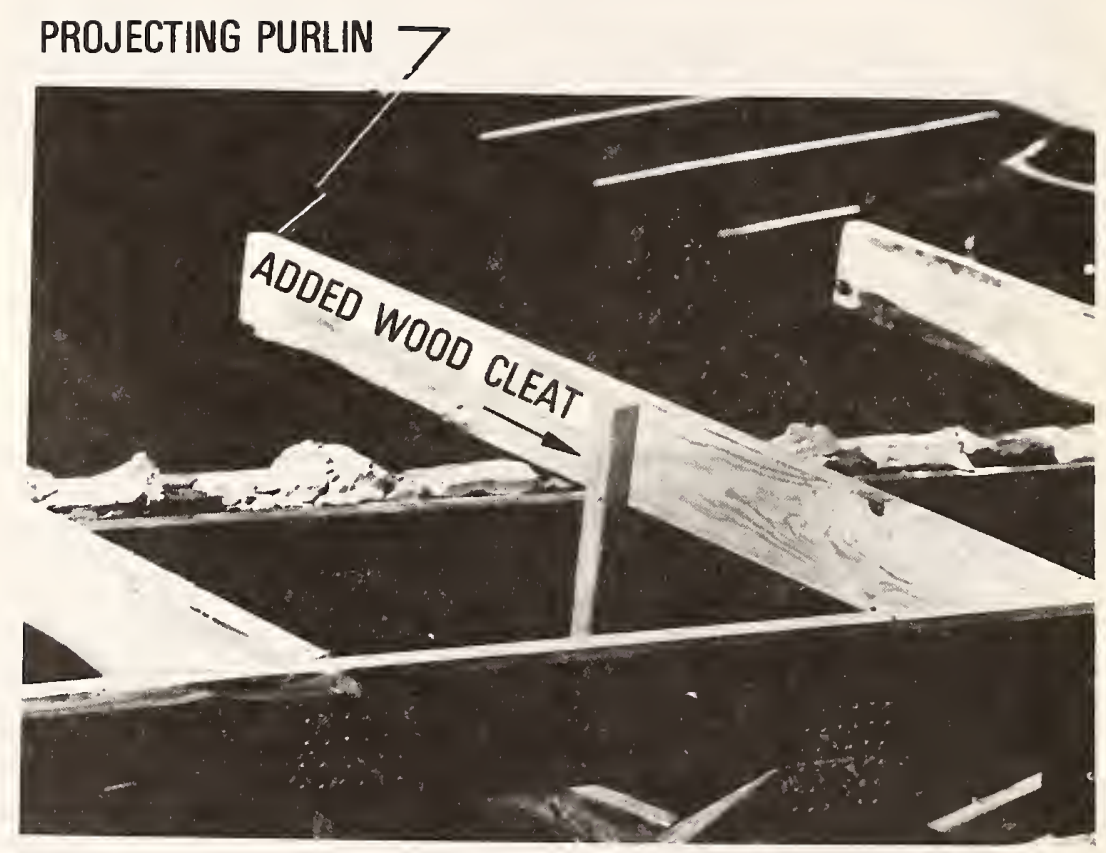

Figure 17 - The addition of a vertical wood cleat for increased uplift resistance along windward edge of roof. 
4.3 Failure of a Brick Gable Wall and a Roof Overhang in a Three-Story Wood Frame - Brick Veneer Apartment Building

An overall view of the damaged building under repair is shown in figure 18. Figure 19 shows a closer view of the damaged wall and roof overhang. Figure 20 shows a similar undamaged wall in an adjacent building.

In this case the wind acted normal to the plane of the gable wall, pushing the wall into the building. The following failure mechanism is envisioned: First, the overhanging part of the roof consisting of asphalt tile roofing, plywood sheathing and wood purlins was uplifted by the wind and failed; subsequently, the wall was deprived of its lateral support at the top and failed as a cantilever.

It should be noted that although the gable wall was actually a brick veneer wall up to the upper ceiling level, the wood frame structure was not continued beyond that level. Rather, wood strips were nailed to a fiberboard sheathing which was backed up against the brick veneer. This detail is shown in figure 21. Purlins were then nailed to these wood strips which are shown by the arrow. Lateral support for the top of the cantilevering brick wall was provided by these purlins which were framed into the first roof truss (following the gable wall) and by the plywood sheathing resting on top of these purlins. When the purlins and the plywood sheathing were lifted up by the wind, the brick wall lost its lateral support and was subsequently pushed in. The cantilevering roof section was completely broken off and came to rest on the roof of the building as shown in figure 22 . 


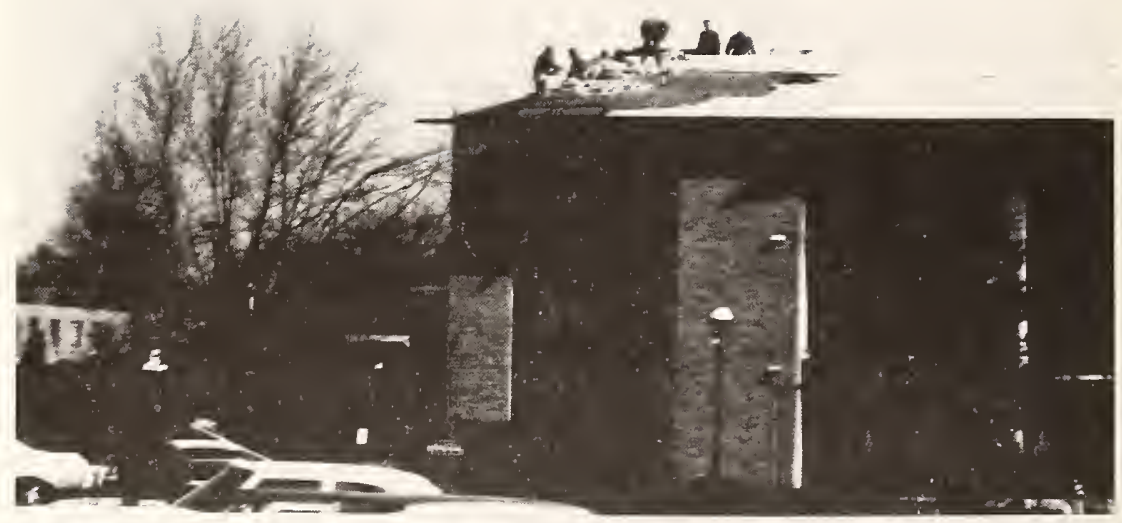

Eigure 18 - Partial view of a damaged roof overhanging a gable wall. Looking northwest. 


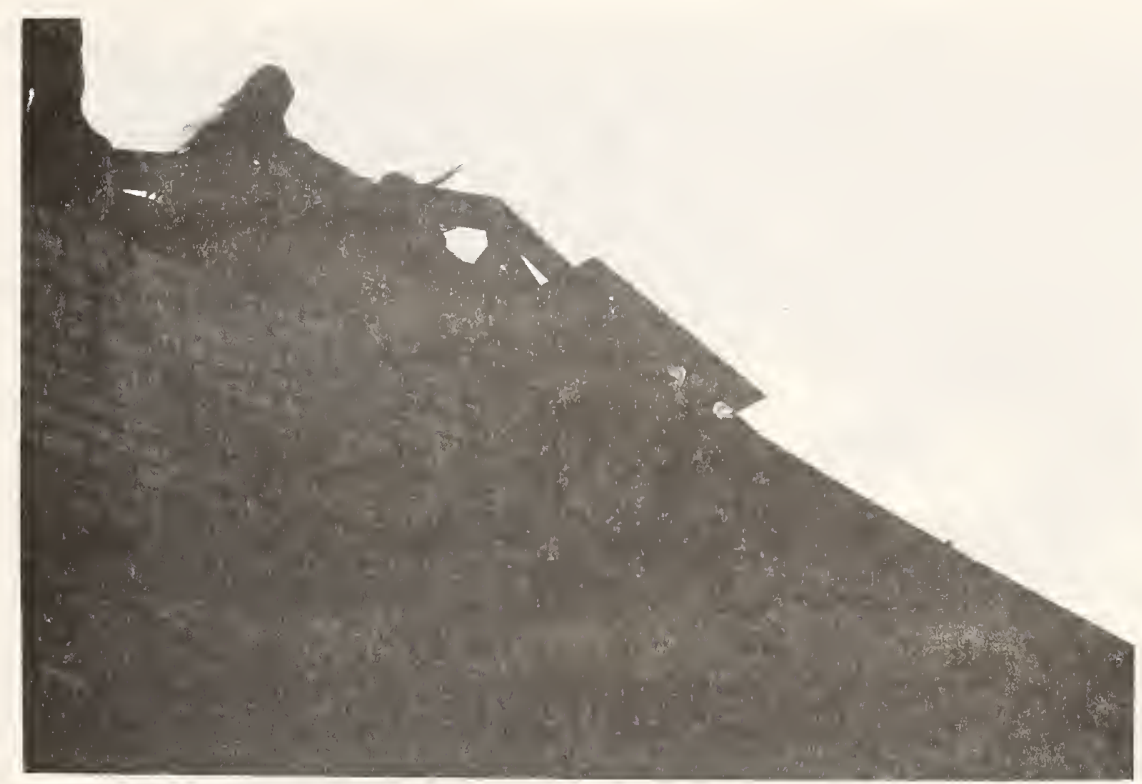

Eigure 19 - A damaged brick veneer gable wall and roof overiang under repair.

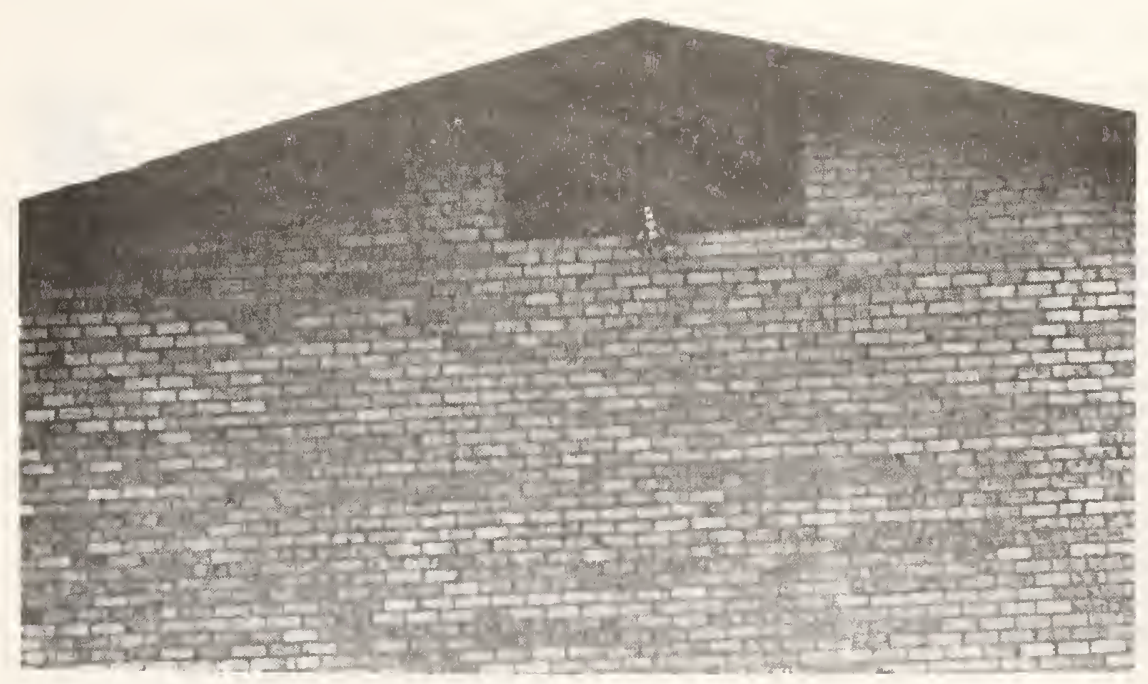

Figure 20 - Elevation view of an undamaged gable wall. 


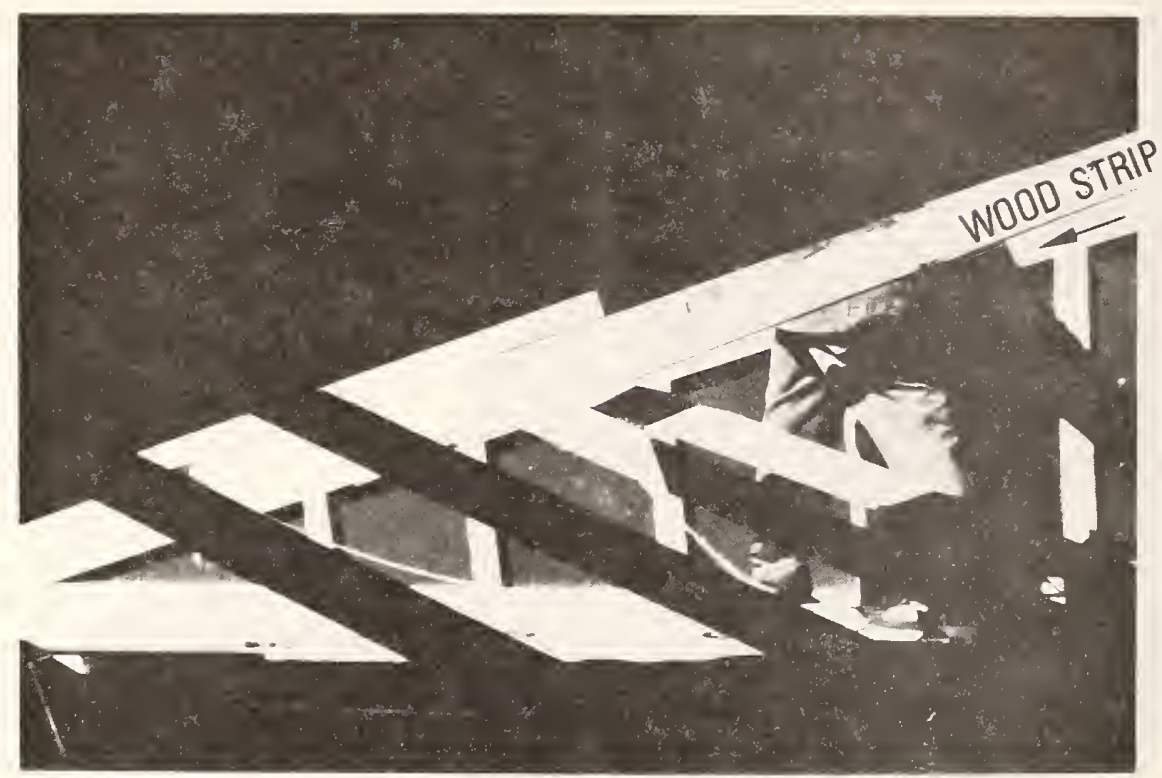

Figure 21 - Details along the back side of the damaged gable wall. Looking west.

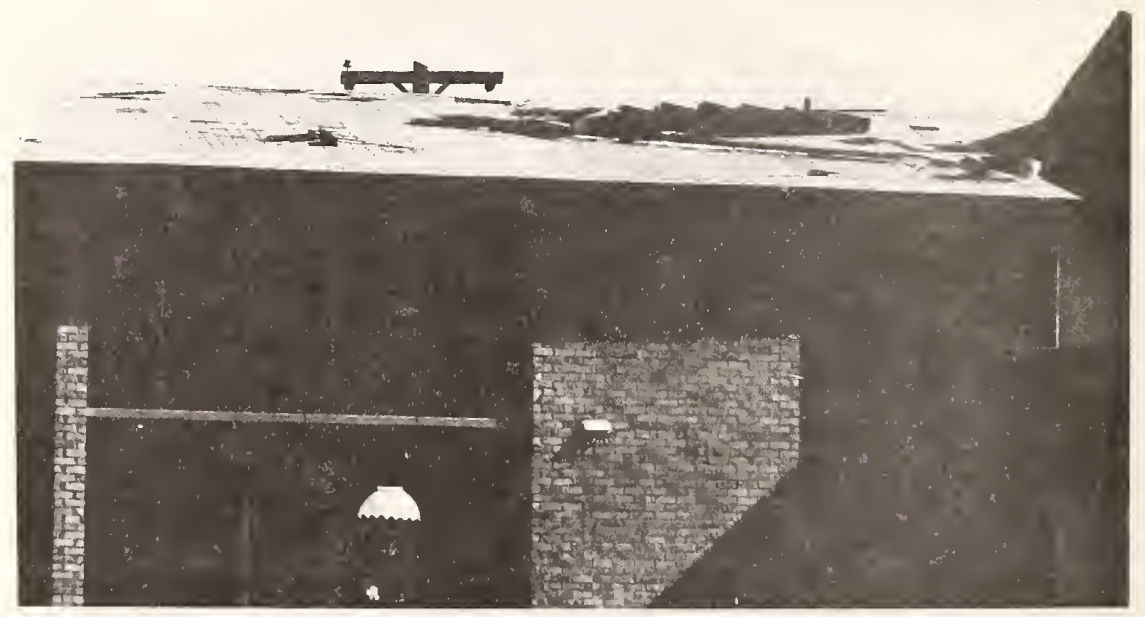

Figure 22 - View of a portion of the damaged overhanging roof. 
4.4 Dynamic Response of Concrete Masonry Infill Walls in a Penthouse Figure 23 shows part of a $13 \mathrm{ft}(4.0 \mathrm{~m})$ high penthouse which is built on top of a 12-story office building. The office building has a flat roof and the penthouse, which houses mechanical equipment, is located about $15 \mathrm{ft}(4.6 \mathrm{~m})$ from the edge of the flat roof. The structure of the penthouse consists of a concrete frame with infill masonry walls. As can be seen in figure 23, most of the masonry walls are covered by decorative stucco. Typically, the infill wall is 8 in $(20.3 \mathrm{~cm})$ thick hollow concrete block. The columns are 30 in $\mathrm{x}$ $22 \mathrm{in}(76.2 \mathrm{~cm} \times 55.9 \mathrm{~cm})$ and the masonry panels are $13 \mathrm{ft}(4.0 \mathrm{~m})$ wide. The roof overhang shown in the figure projects from a 12 in $(30.5 \mathrm{~cm})$ deep beam which rests on top of the concrete block panels, thus making the panels infill panels inside a concrete frame. There is also a concrete beam along the bottom of the masonry panels. The prevailing wind direction was normal to the plane of the wall and the loads acted inward as shown by the arrow in figure 23. The effect of the wind was to cause a violent dynamic response of the masonry infill walls. Eyewitnesses reported that "the wall was wavering visibly in an inward and outward fashion, apparently pivoting about its bottom." It is difficult to interpret this statement exactly but evidently the wall was flexing in and out with an amplitude large enough to be clearly distinguishable by an observer. Inadequate restraint at the top of the wall may have contributed to the large deflections. The flexing of the wall did not lead to a failure, although there is substantial evidence of local distress. Figure 24 shows a view of the bottom of the wall at the interior of the penthouse. Note the crack between the bottom course of the masonry and the concrete beam at the bottom of the wall. Figure 25 shows a similar crack between the top of the masonry wall and the top concrete beam. The picture was taken in the interior of the penthouse in a part which is not covered by a roof (the cooling tower area). Figure 26 shows bracing which was installed in the interior of the penthouse during the storm in order to stabilize the infill panels. The building was evacuated during the storm because of fear that collapse of infill walls might 
cause a breakdown in the mechanical system of the building, and the area around the building was roped off to protect passersby from the hazard of falling debris. 


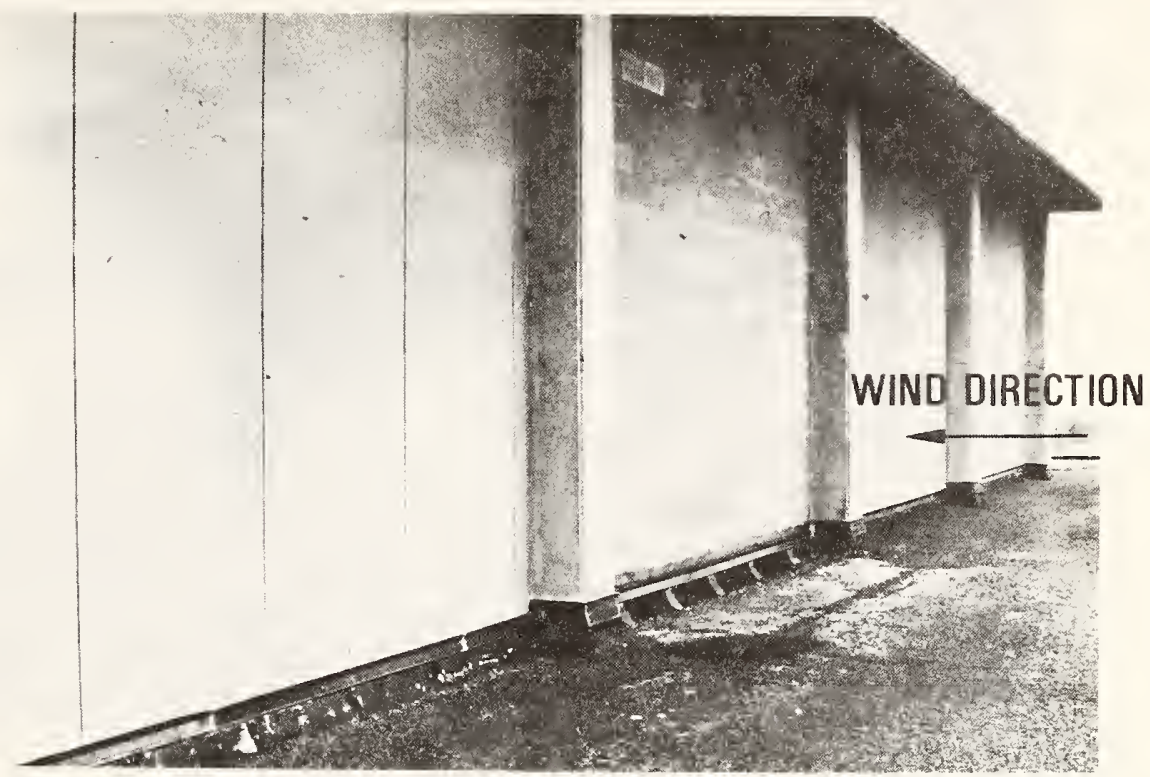

Figure 23 - Exterior view of the damaged masonry walls of a mechanical equipment penthouse. Looking south.

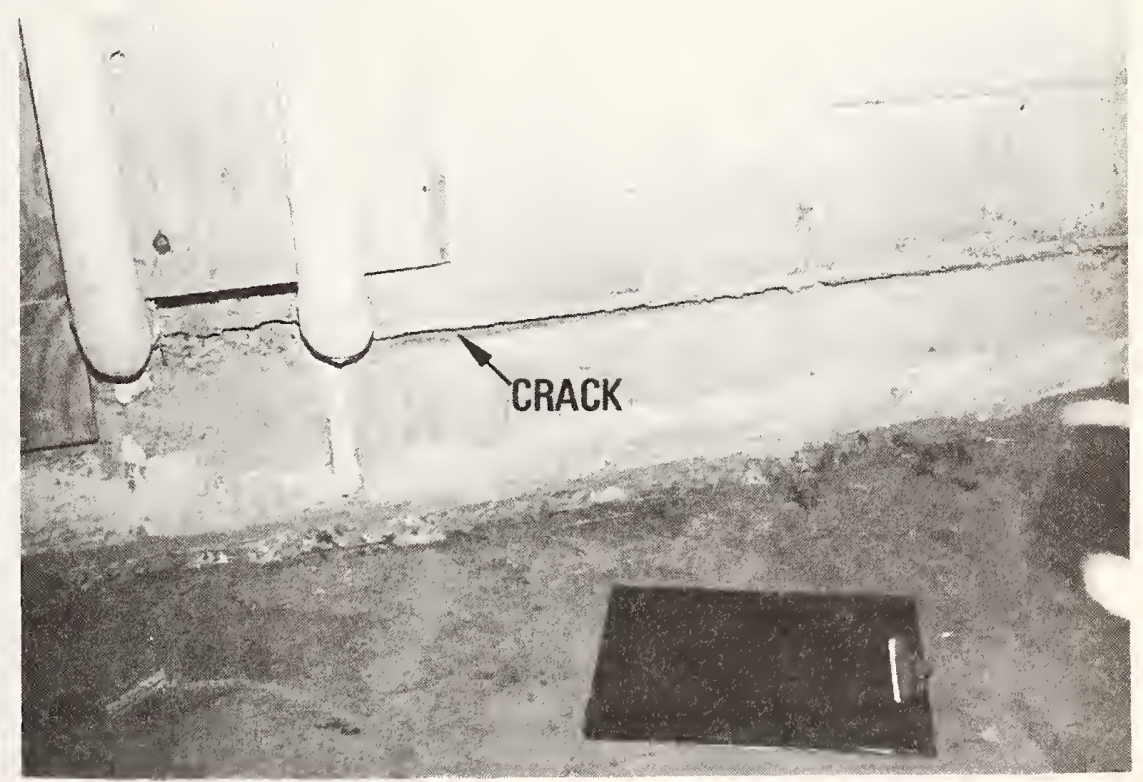

Figure 24 - View of the bottom of a damaged wall at the interior of the penthouse. 


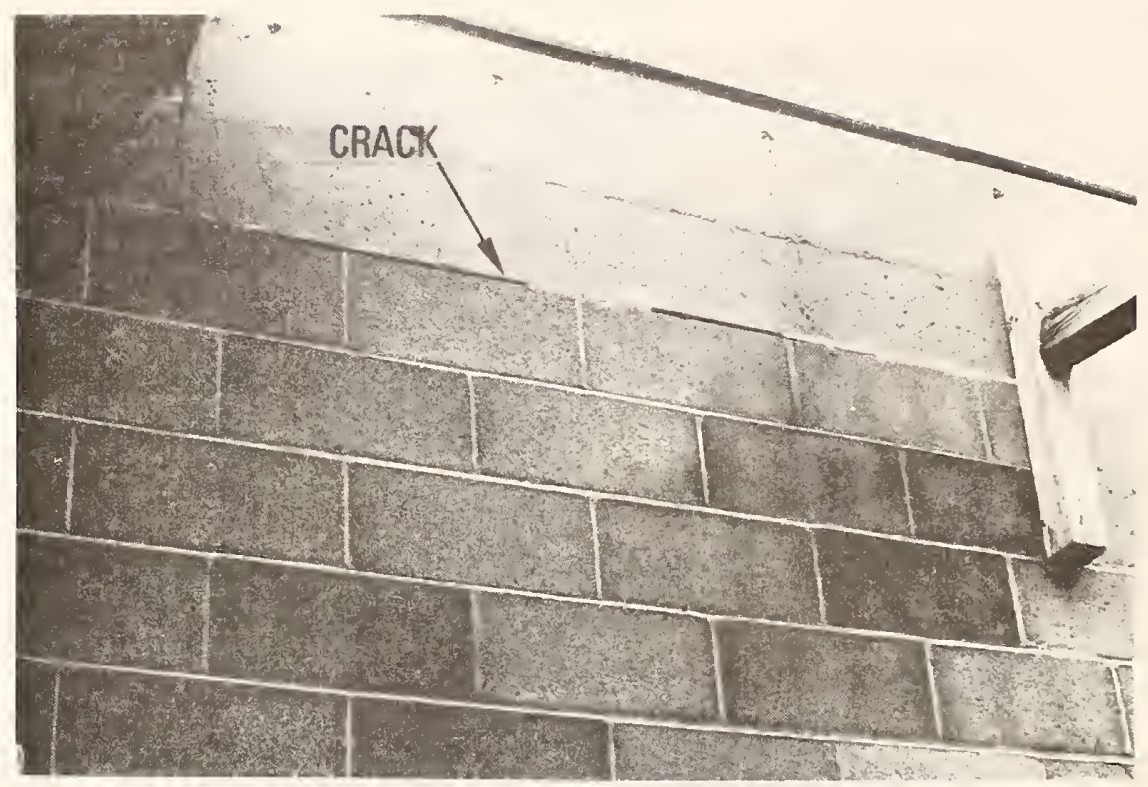

Figure 25 - Mortar crack between top of masonry wall and bottom of concrete beam.

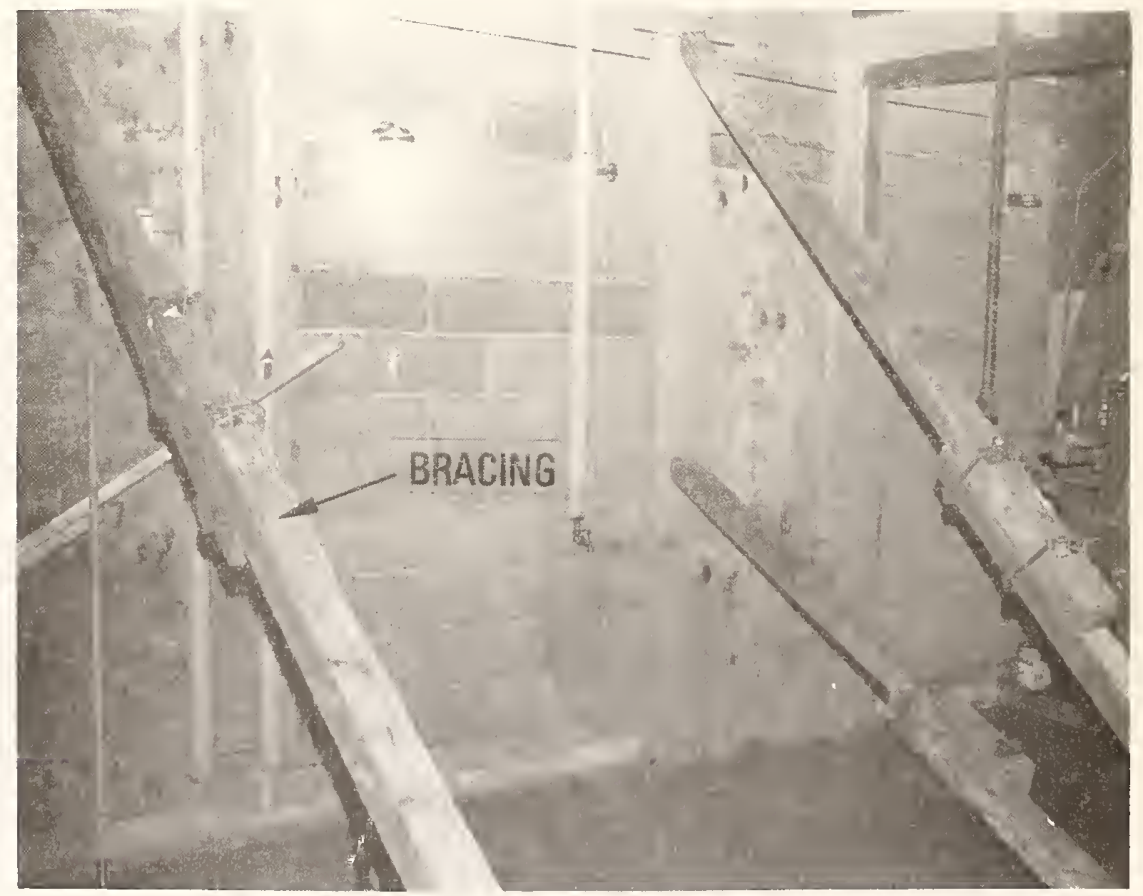

Figure 26 - Typical timber bracing used along the interior side of damaged wall. 
4.5 Roof Damage in a Three-Story Garden Apartment Complex

Figure 27 shows a front elevation of a typical three-story unit of a garden apartment complex with flat mineral surface built-up roofs. Figures 28-31 show overall views of the roof damage suffered by the apartment complex. The prevailing wind direction is shown in figure 28. The figure also shows that the roofs overhanging the balconies were ripped off by the wind. The view through the window on the upper left of figure 29 shows that part of the roof and ceiling over the living unit is removed. Another front view of the damage is given in figure 30 and a side view in figure 31 . Figure 32 shows some of the debris of the collapsed roof. The roof construction consisted of $2 \times 8$ (5 × $20 \mathrm{~cm}$ nominal) wooden joists 24 inches $(61.0 \mathrm{~cm})$ on centers with plywood on both sides of the joists. This flat roof was then covered with a composite roofing. No information was available on the anchorage between the joists of the roof structure and the masonry walls of the building and no evidence of anchorage could be found in the field examination. Apparently, the wind exerted substantial uplift on the overhanging portions of the roof and in particular on sections of the roof covering the balconies. Evidence of this uplift can be seen in Figure 33. Note the separation between the roof (which is in this case still in place) and the masonry wall. Figure 34 shows that the portion of the roof overhanging the balcony was supported by a beam which in this case stayed in place while the roof was demolished. In figure 35 a case is shown where the beam was also pulled out from its bearing socket. An overall view of the roof under repair is shown in figure 36. The areas under repair in this figure give an indication of the extent of the damage suffered. 


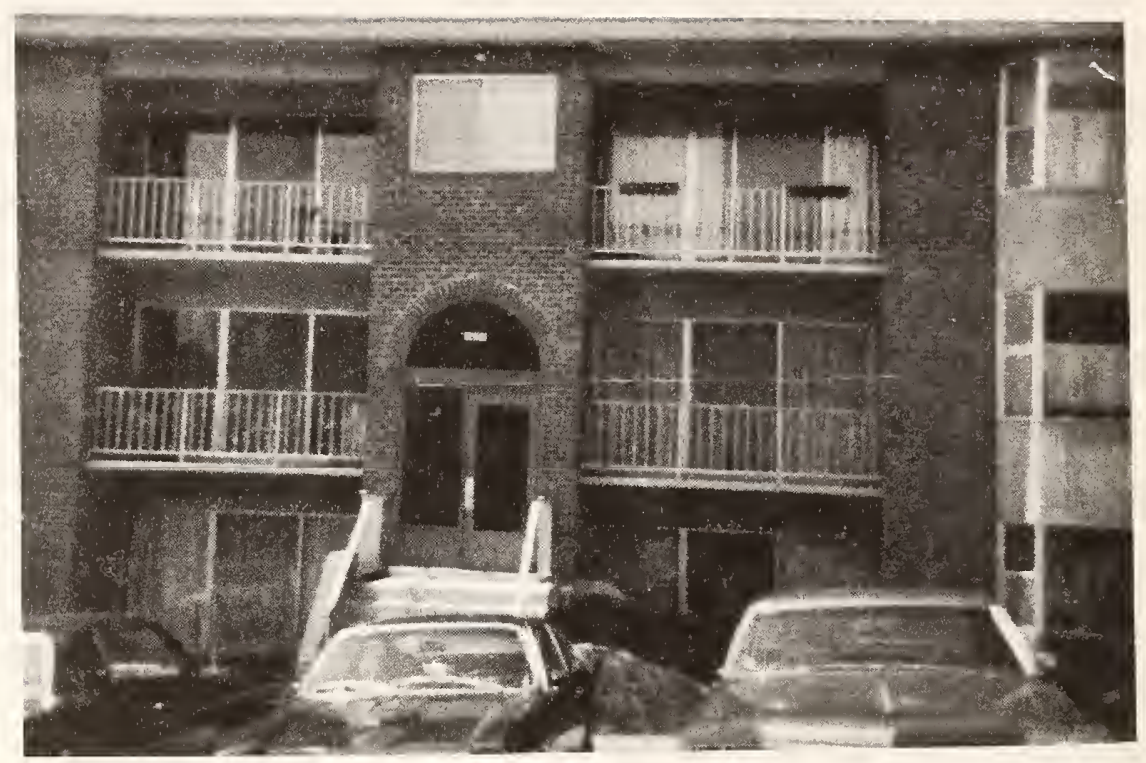

Figure 27 - Front elevation of a typical three-story apartment buizding.

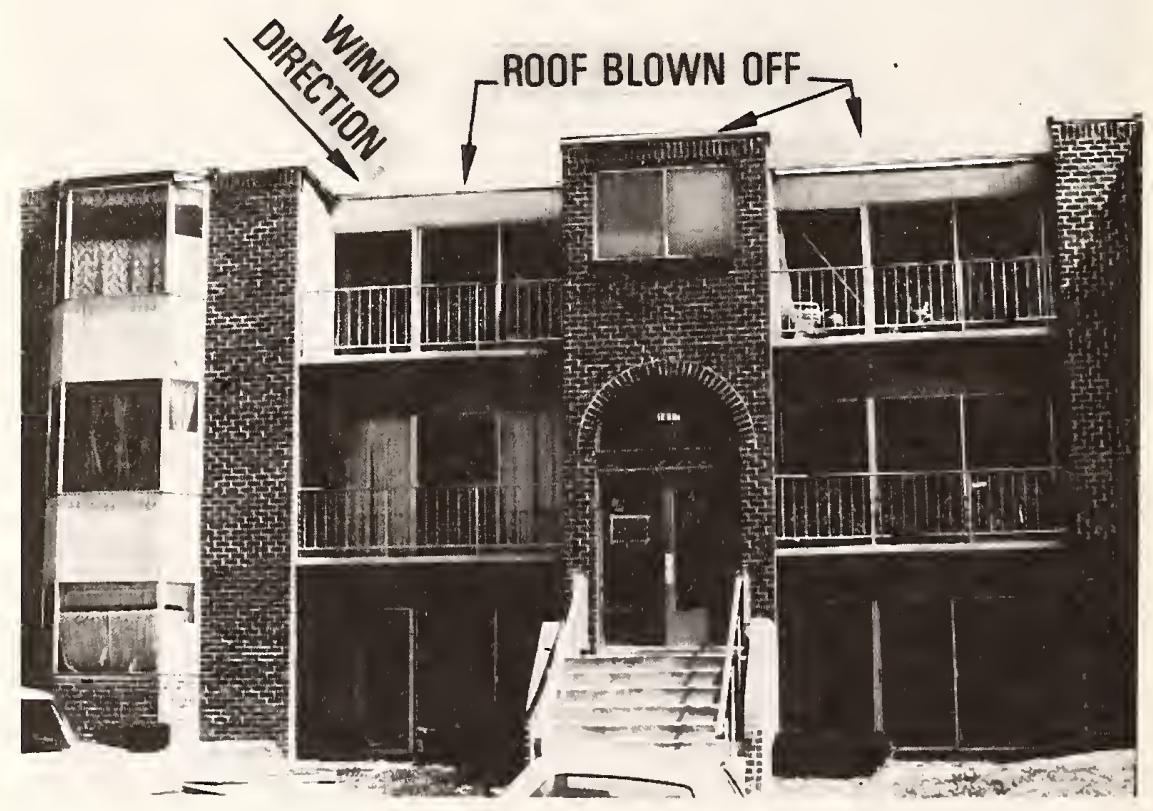

Eigure 28 - Front elevation of a building which sustained roof damage. Looking east. 


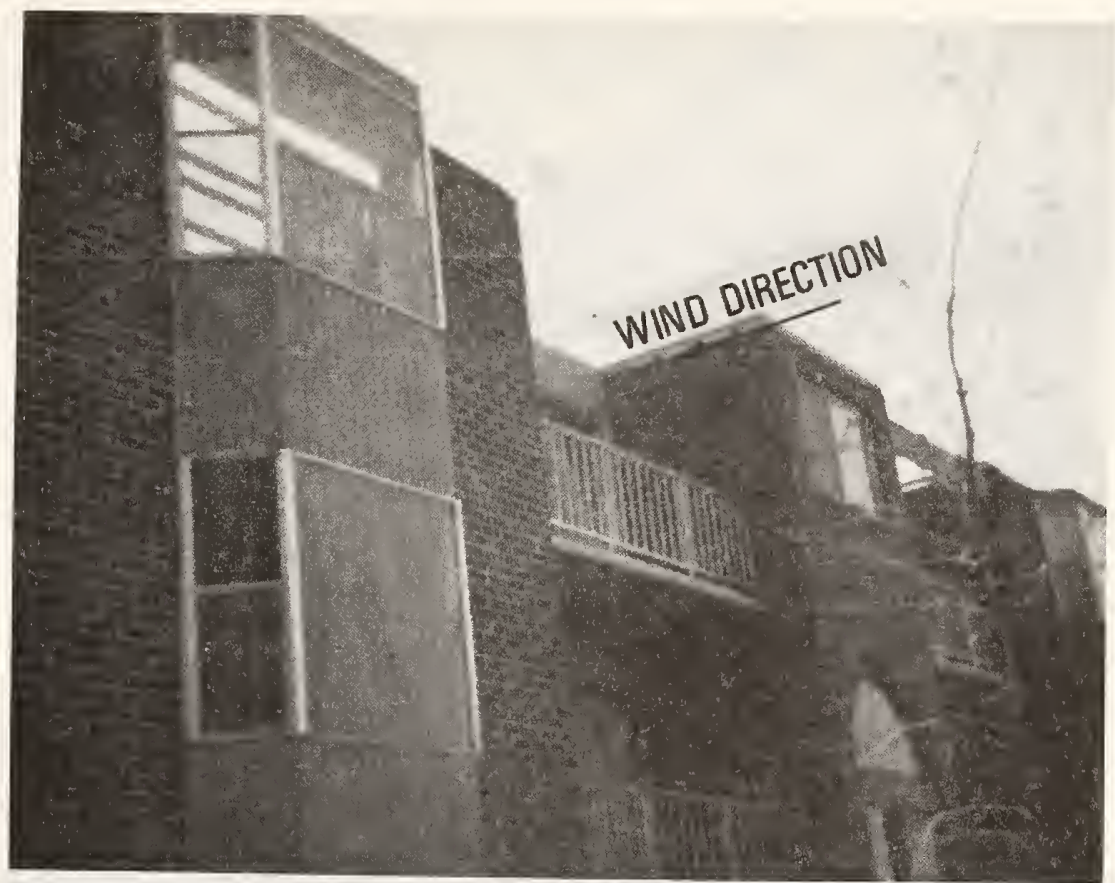

Figure 29 - Closeup view of damage showing loss of roof over living unit and balcony.

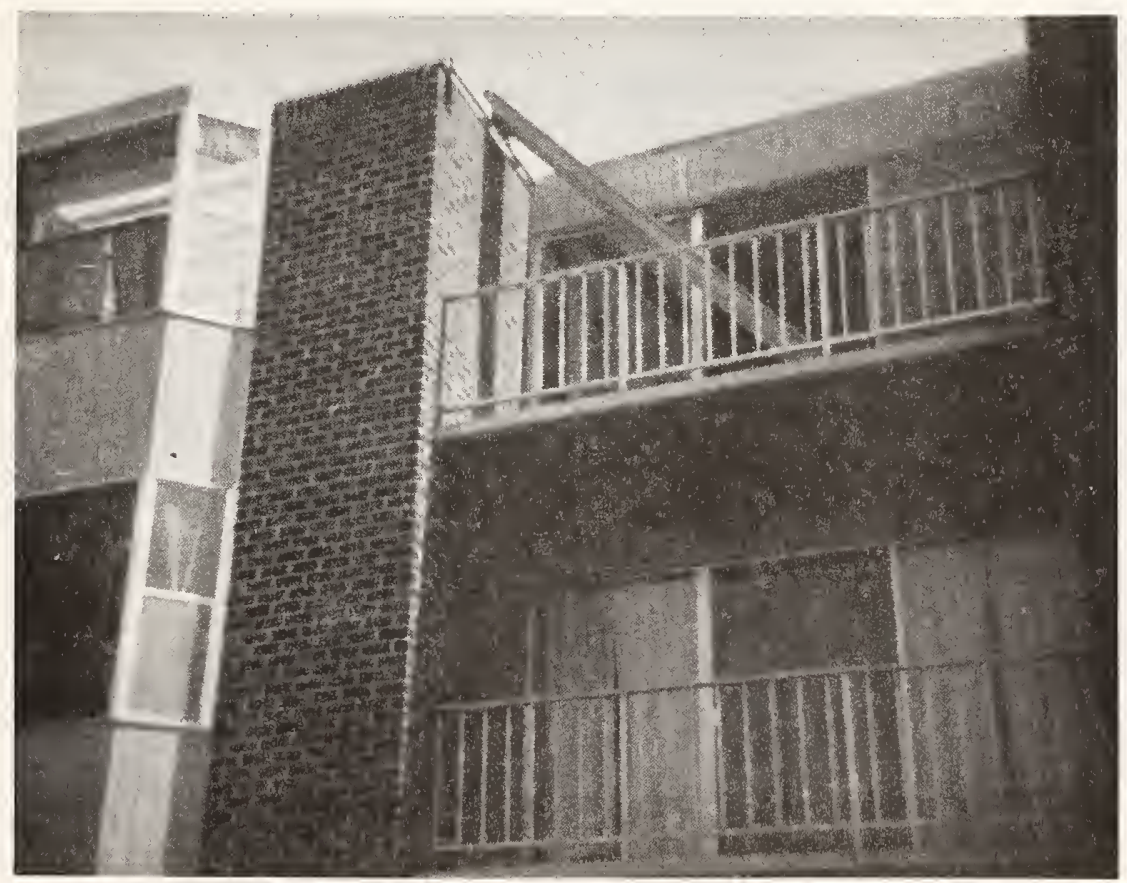

Figure 30 - Closeup view of damage above third-story balcony. 


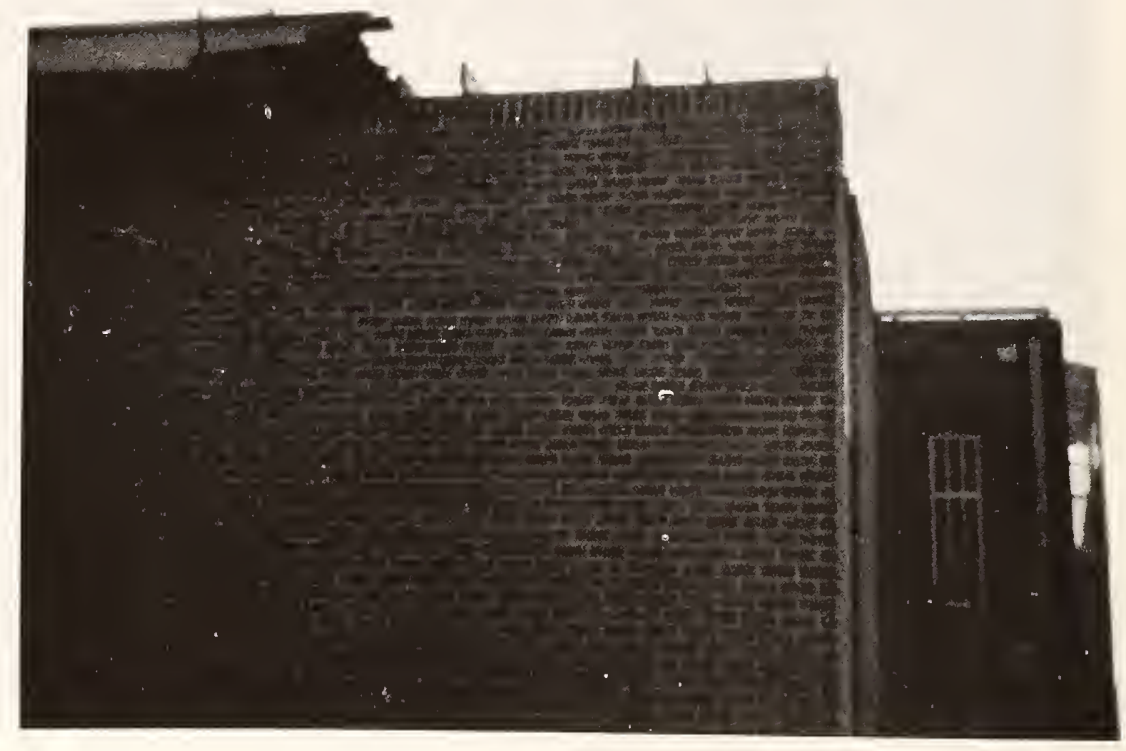

Figure 31 - Side view of domaged buizding showing partial destmution of roof.

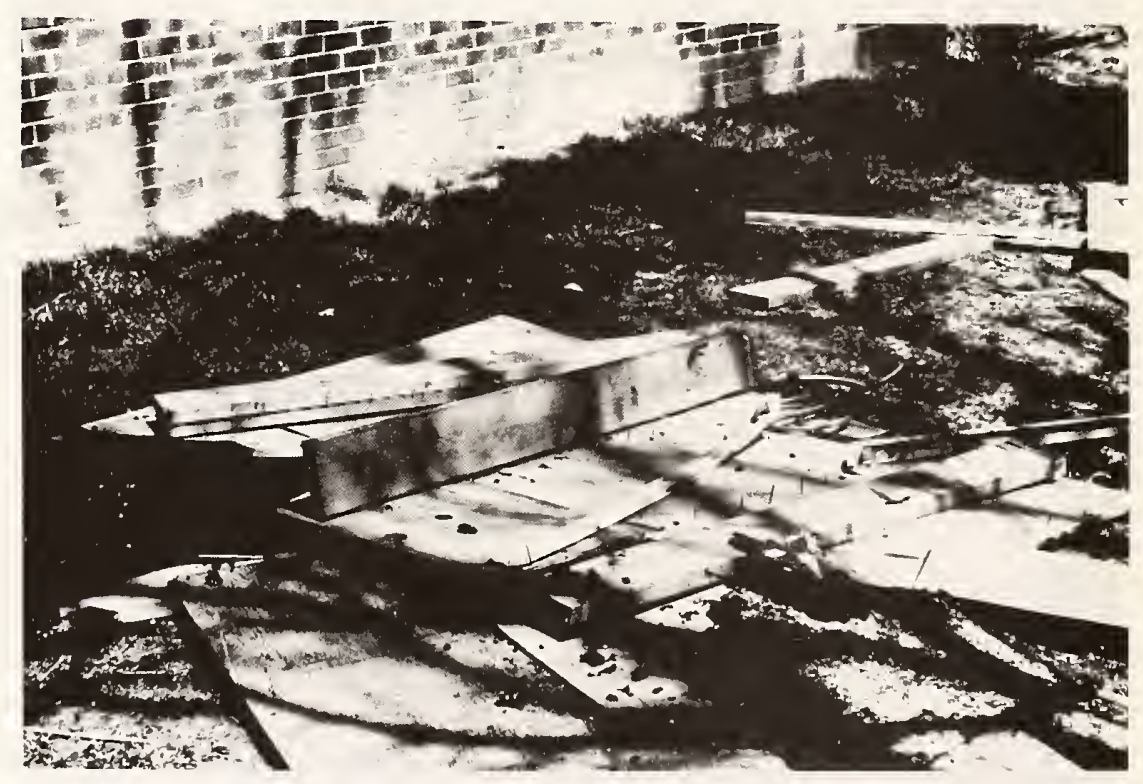

Figure 32 - Ground-level view of some wood framing and sheathing from a damaged roof. 


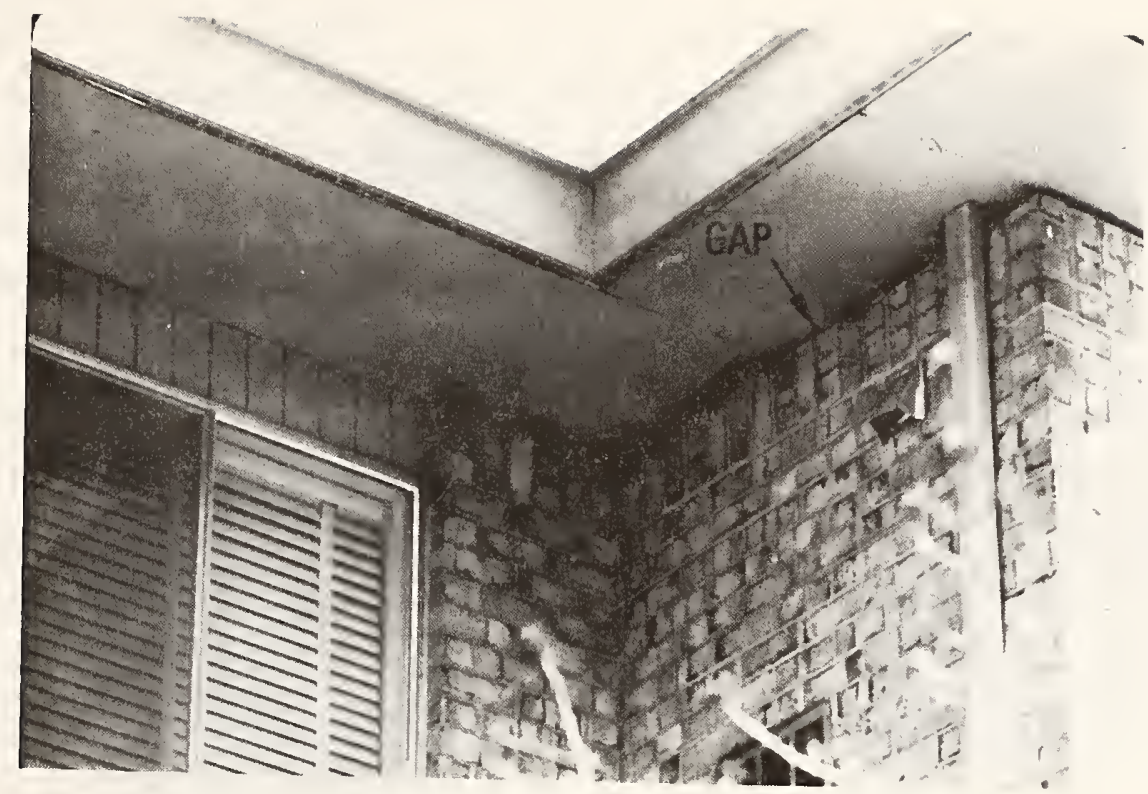

Figure 33 - Residual separation between soffit and masonry wall caused by uplift on roof overhang.

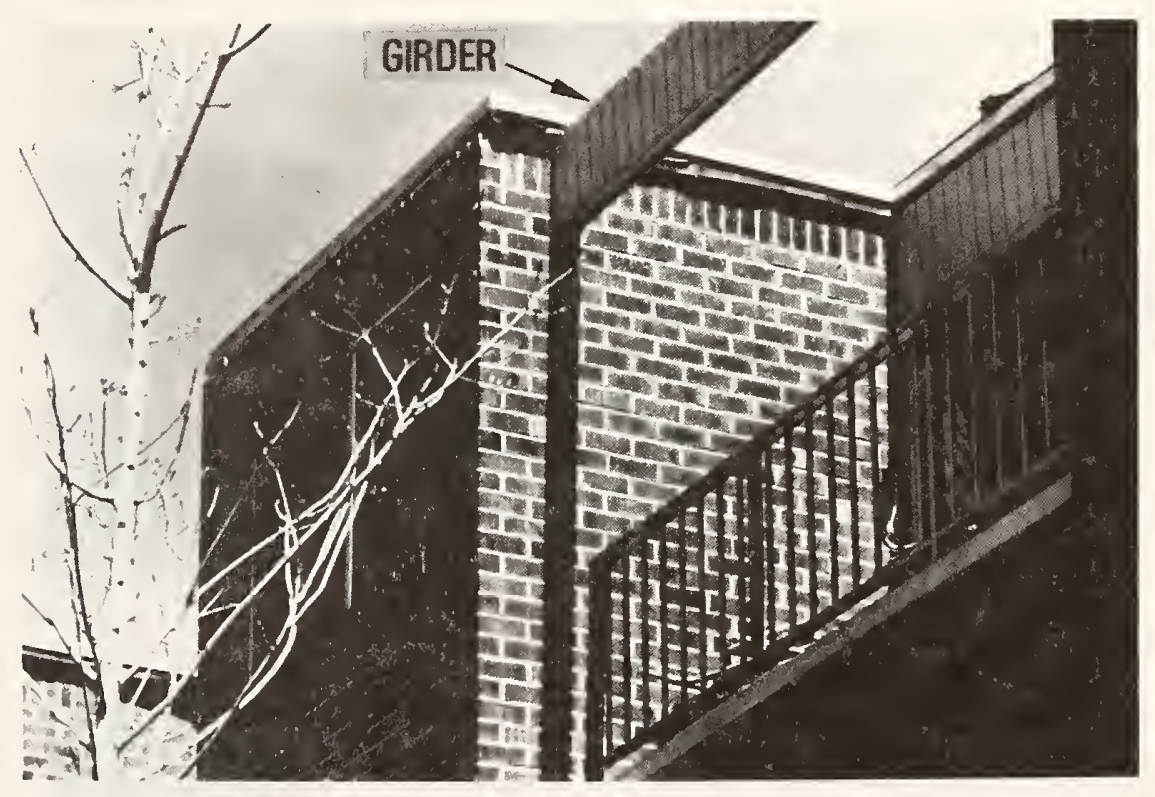

Figure 34 - Girder which supported portion of roof that covered balcony. 


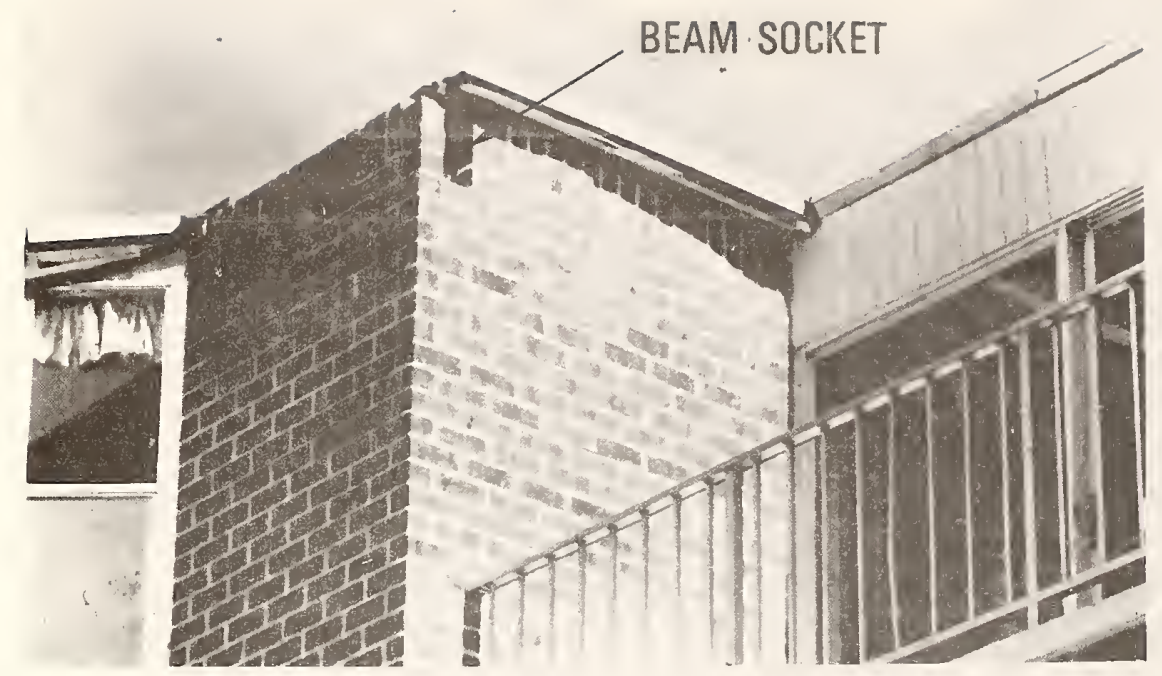

Figure 35 - A balcony above which the roof and supporting girder were removed.

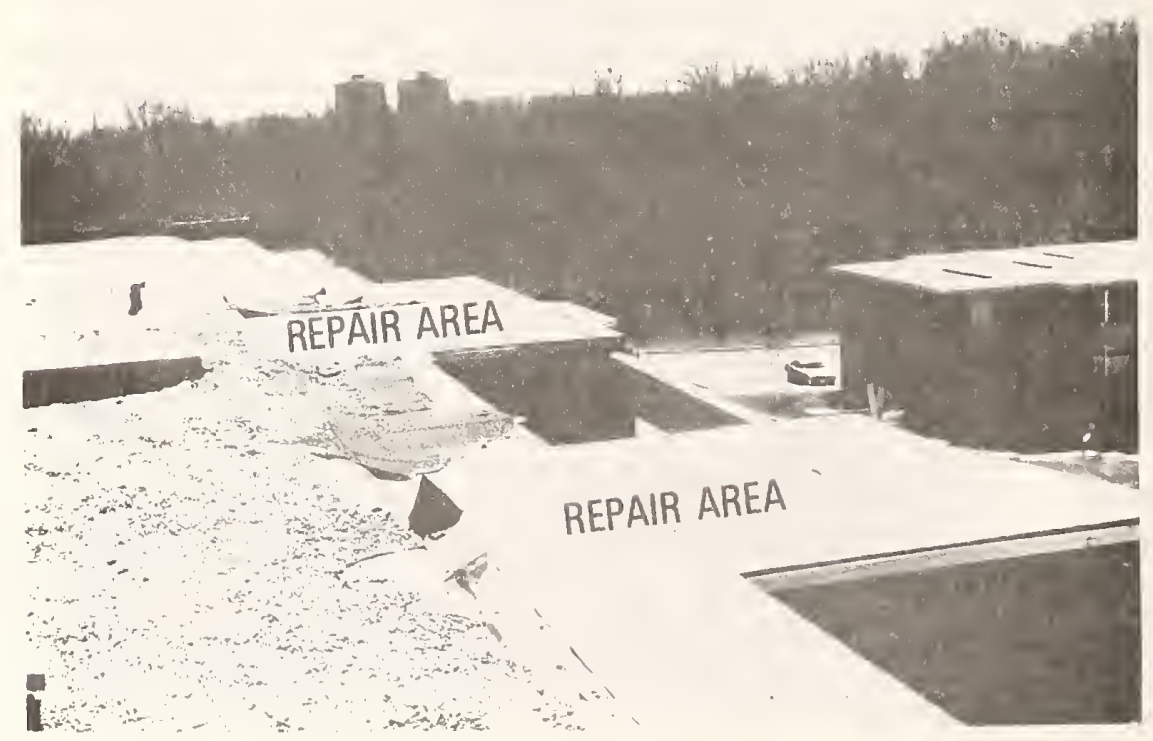

Figure 36 - Overalz view of roof under repair. 
4.6 Failure of a Roof under Construction

Figure 37 shows a three-story garden apartment building. This is one of the completed units which suffered no damage. Figure 38 shows a row of the same type of units under construction. The prevailing wind direction is indicated by the arrow. Note that in the completed unit (figure 37) the truss structures which support the roofs are closed by siding, giving the appearance of a mansard. Figure 38 shows part of the roofs which were removed by the wind and deposited in front of the buildings under construction. A closer look at an undisturbed roof assembly in place is shown in figure 39. Figures 40 and 41 show details of the roof assemblies which were lifted up, overturned and deposited on the ground. The truss structure had wooden top and bottom chords and galvanized steel tubing as diagonal truss members. The top of the roof was covered by $1 / 2$ in $(1.3 \mathrm{~cm})$ thick plywood sheathing. Although this plywood sheathing was in place, the built-up roofing had not yet been installed. The span length of the trusses was 49 $\mathrm{ft}(14.9 \mathrm{~m})$ and spacing between trusses was 24 in $(61.0 \mathrm{~cm})$. Connections of the roof trusses to the masonry walls are shown in figures 42 , 43 and 44. Figure 44 shows that not only was the roof truss structure removed, but also a steel beam which served as a lintel over a window opening. One of these lintels, in place, is marked by the arrow in figure 45. Two of the displaced lintels are seen, still attached to the trusses in figure 38. The failure of these roofs is probably attributable to two causes: 1. the sides of the trusses were open and the windows were not completed, thus providing openings which caused pressure buildup on the underside of the roof sheathing; this pressure, together with suction acting on the top of roof surface exerted a considerable upward force; 2. the built-up roofing was not yet in place to add weight which could have contributed to the resistance to uplift pressure. Figure 45 shows the details of roof trusses on units which were under construction and which were not damaged by the wind. 


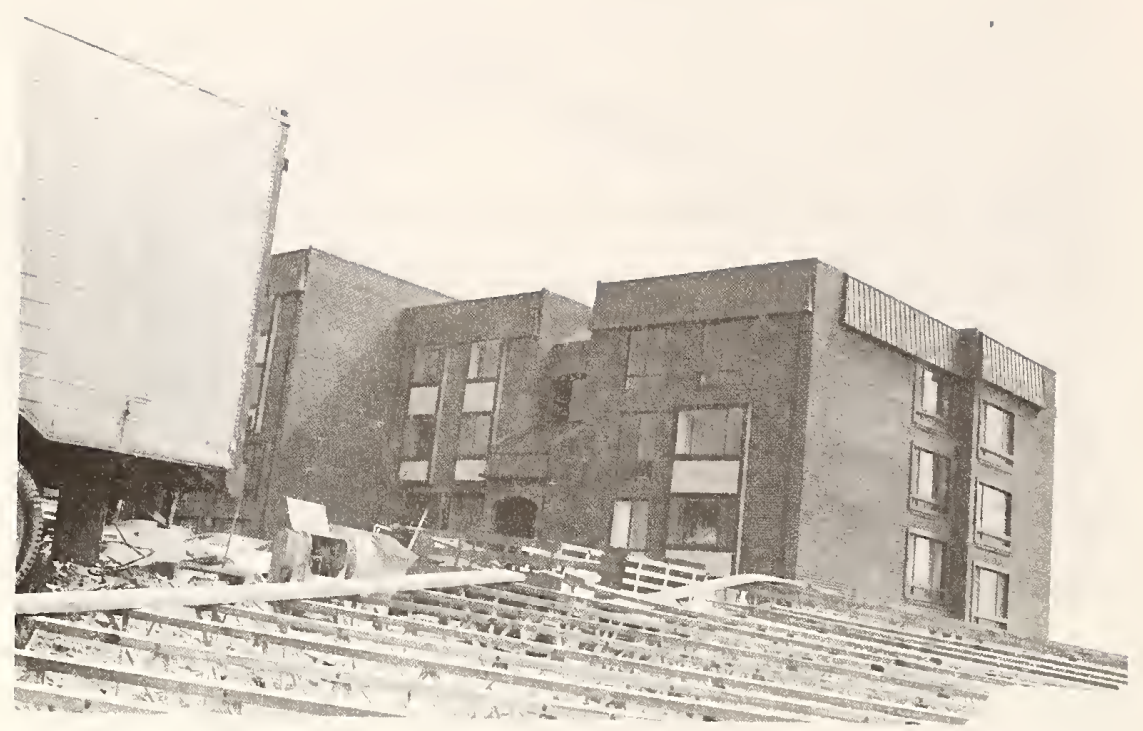

Figure 37 - A completed three-story garden apartment builaing.

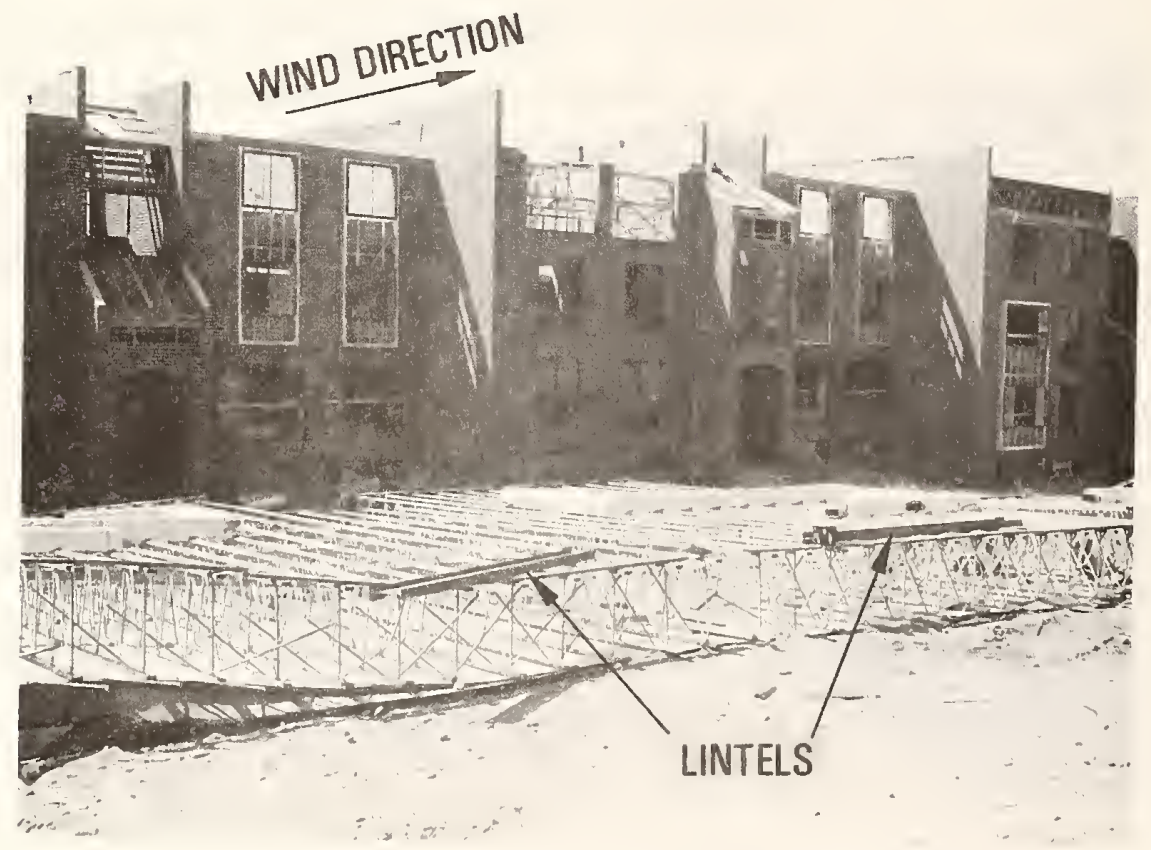

Figure 38 - Front elevation of several buildings under construction from which the roofs were lifted and dropped on the ground. 


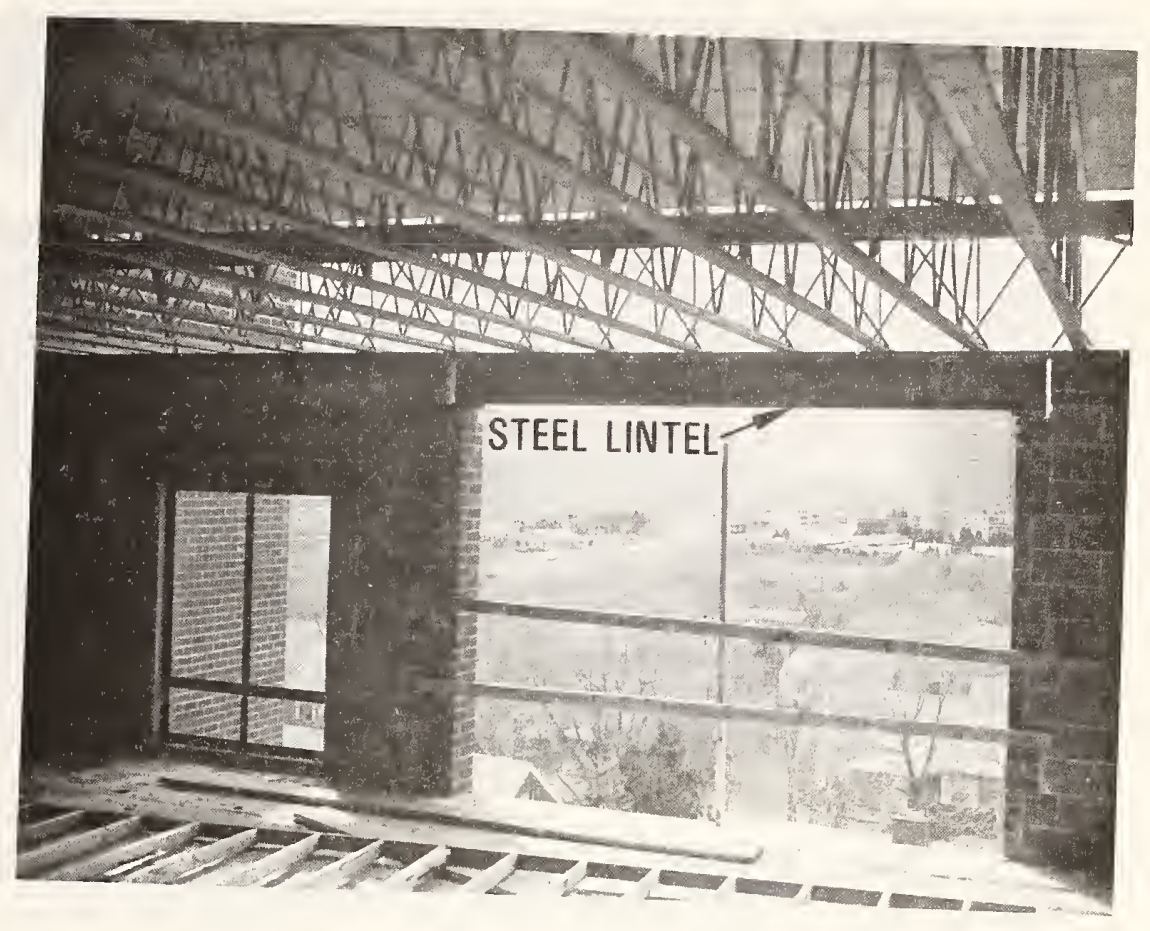

Figure 39 - Closeup view of the underside of a typical roof
assembly.

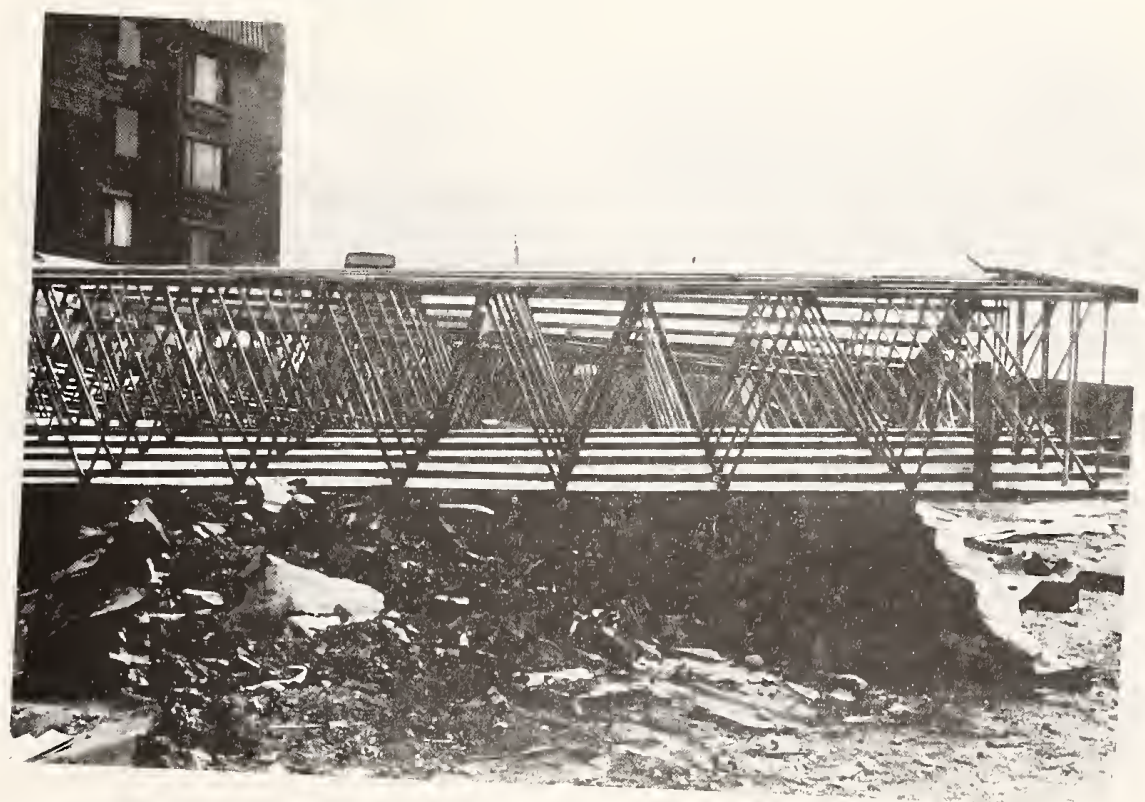
Figure 40 - Side elevation of the roof assembiies lifted up
and deposited on the ground. 


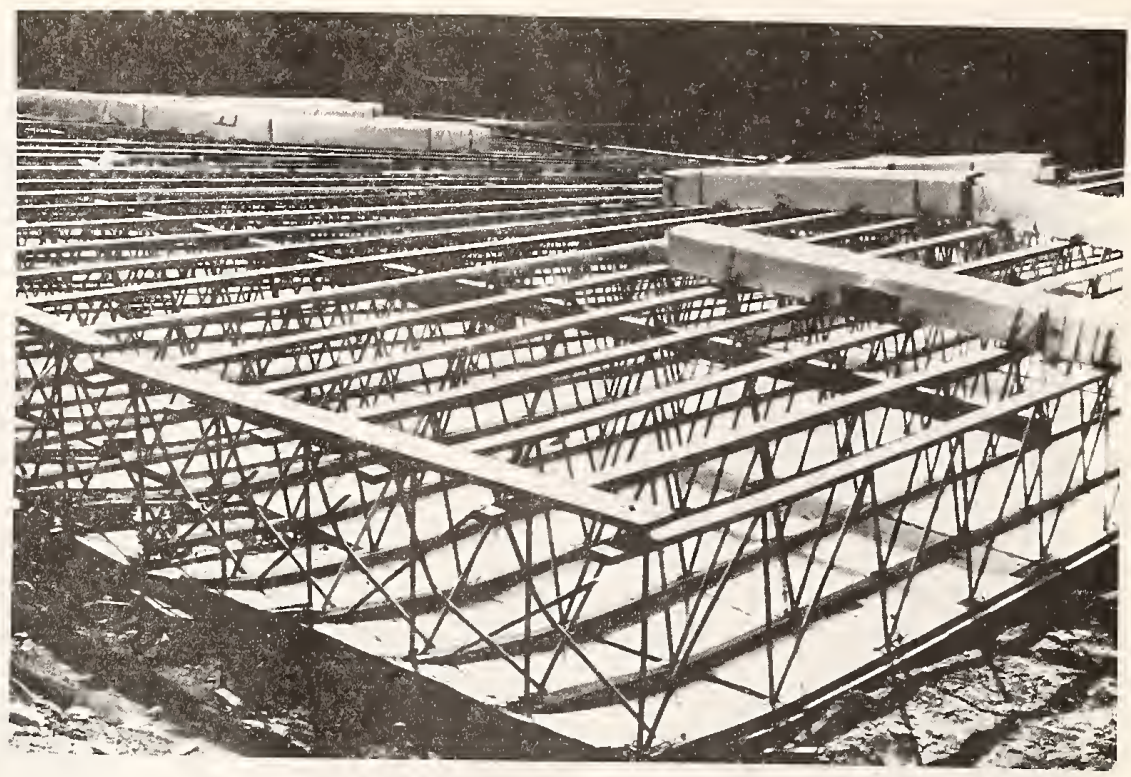

Figure 41 - Closeup view of overturned roof assemblies.

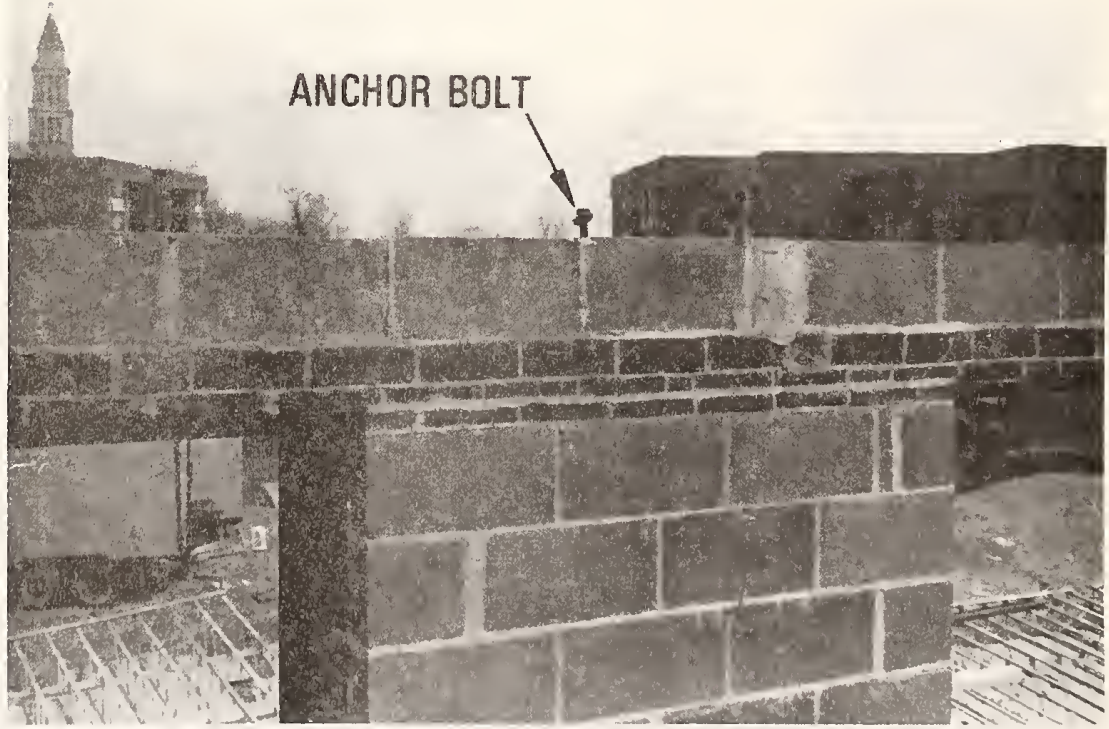

Figure 42 - A front masonry wall with projecting bolt for anchoring the roof assembly. 


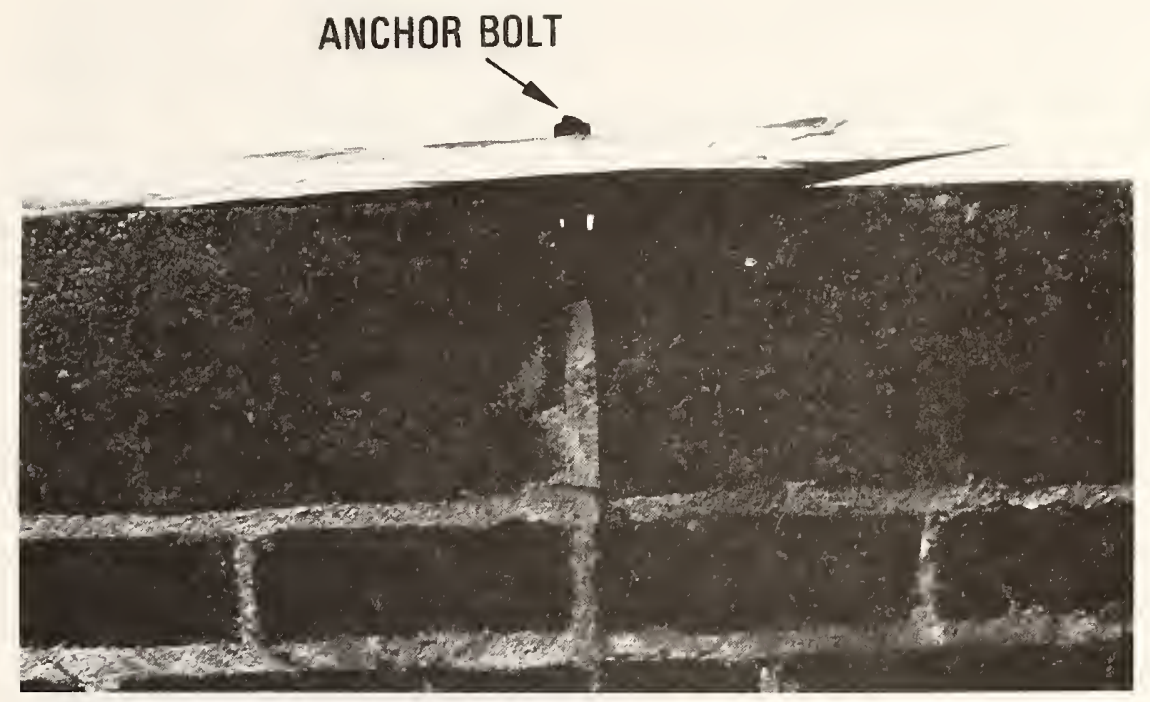

Figure 43 - A portion of a wood bearing plate and a connecting anchor bolt remain atop masonry walz.

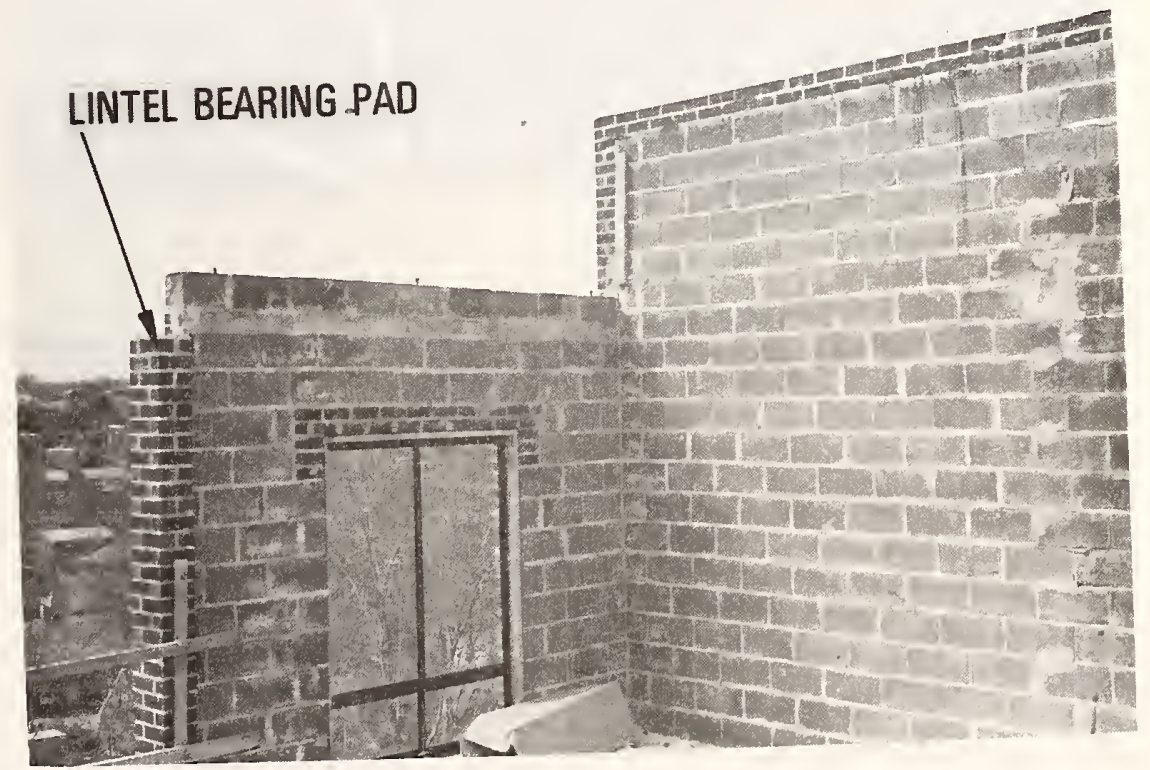

Figure 44 - Elevation of a rear wall from which the roof assembly and lintel beam have been removed. Looking northwest. 


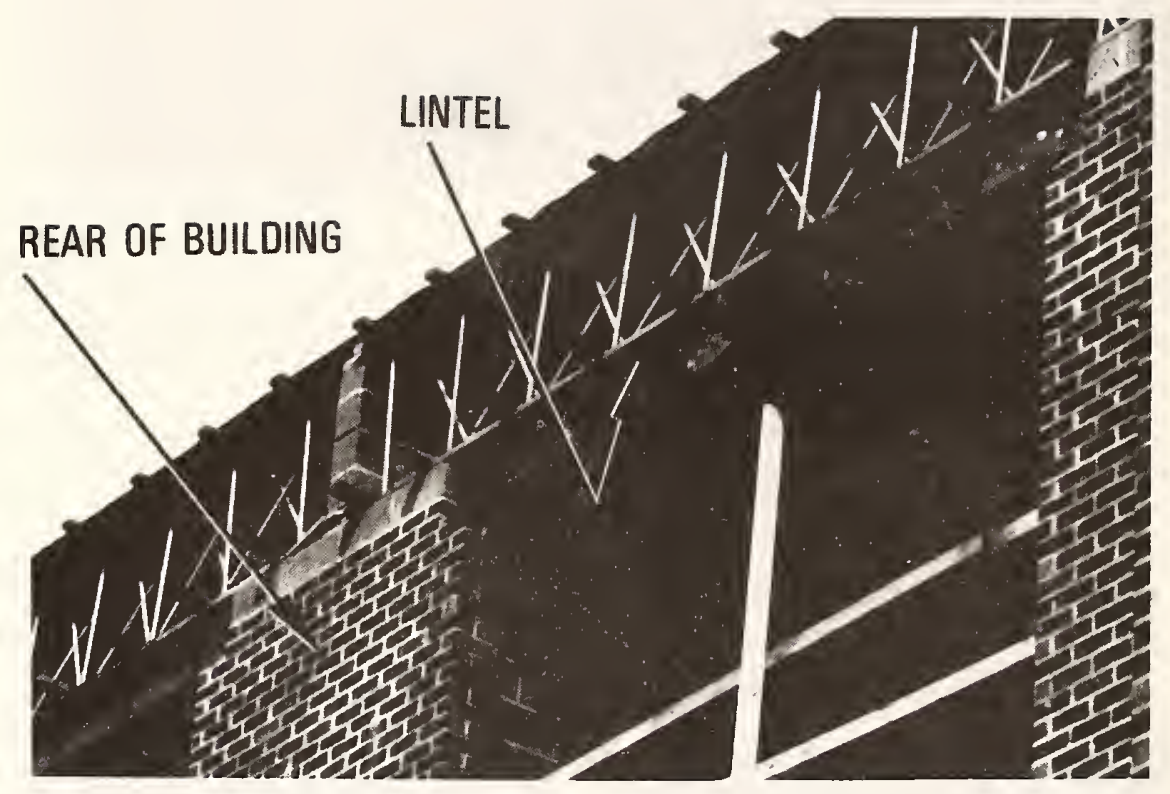

Figure 45 - Rear view of roof truss support in an undamaged buizaing. Looking east. 
4.7 Collapse of Concrete Masonry Walls During Construction

Figure 46 shows the end unit of a four-unit concrete masonry row house under construction. The exterior side wall of this unit collapsed and fell into the street causing two fatalities. (See the debris in the foreground of the photograph). Figures 47 and 48 are other views of the same structure taken from another street at right angles to the one into which the wall collapsed. The direction of the prevailing wind is shown by the arrow in figure 47 . Note the partial collapse (figure 48) of cross-walls in other portions of the structure which were parallel to the exterior wall that collapsed. Details of the pulled-out joint reinforcement in one of the damaged cross-walls is shown in figure 49. The construction was 8 in (20 $\mathrm{cm}$ ) unreinforced hollow concrete block with joint reinforcement. The incident illustrates the vulnerability of masonry walls in the construction stage before they are fully braced at their tops.

Another instance of masonry wall failure during construction is shown in figures 50 and 51 . These walls were braced prior to the storm. 


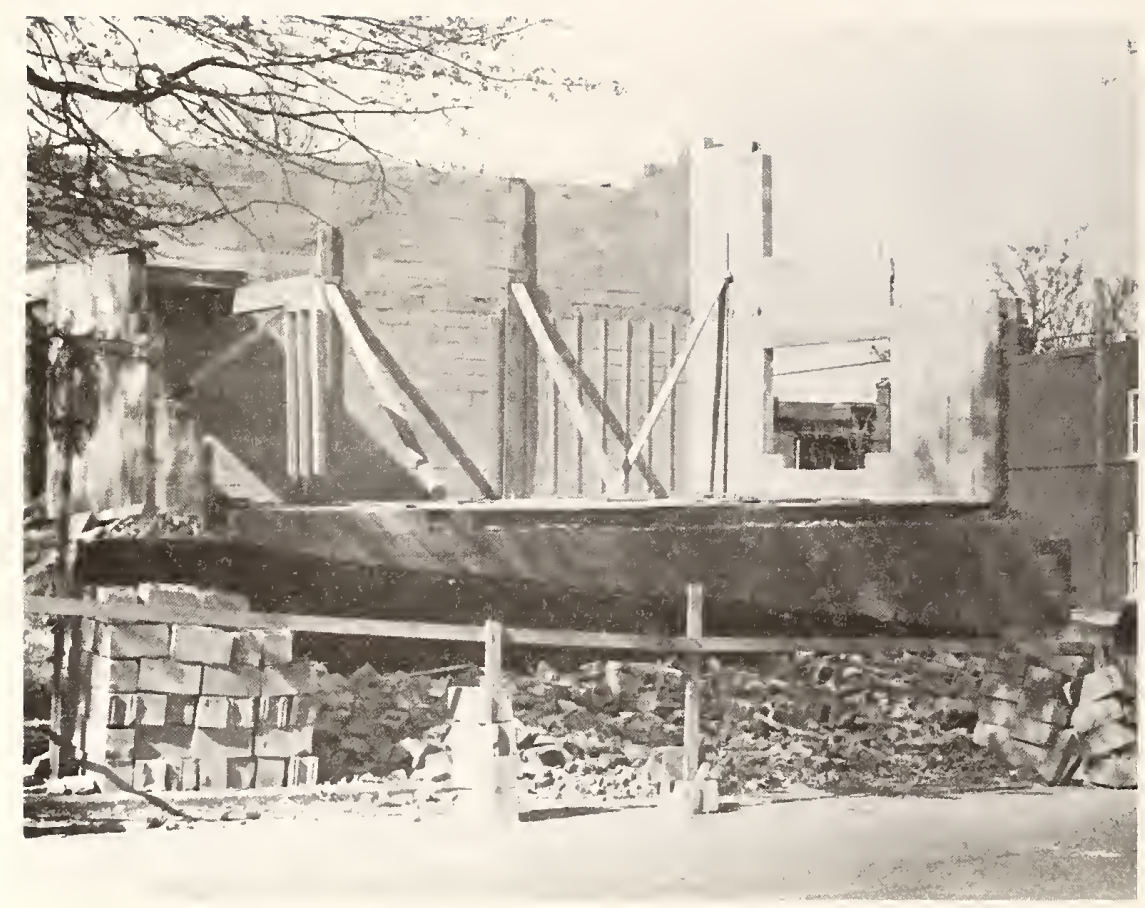

Figure 46 - End living unit of a four-unit masonry row house complex damaged during construction. 


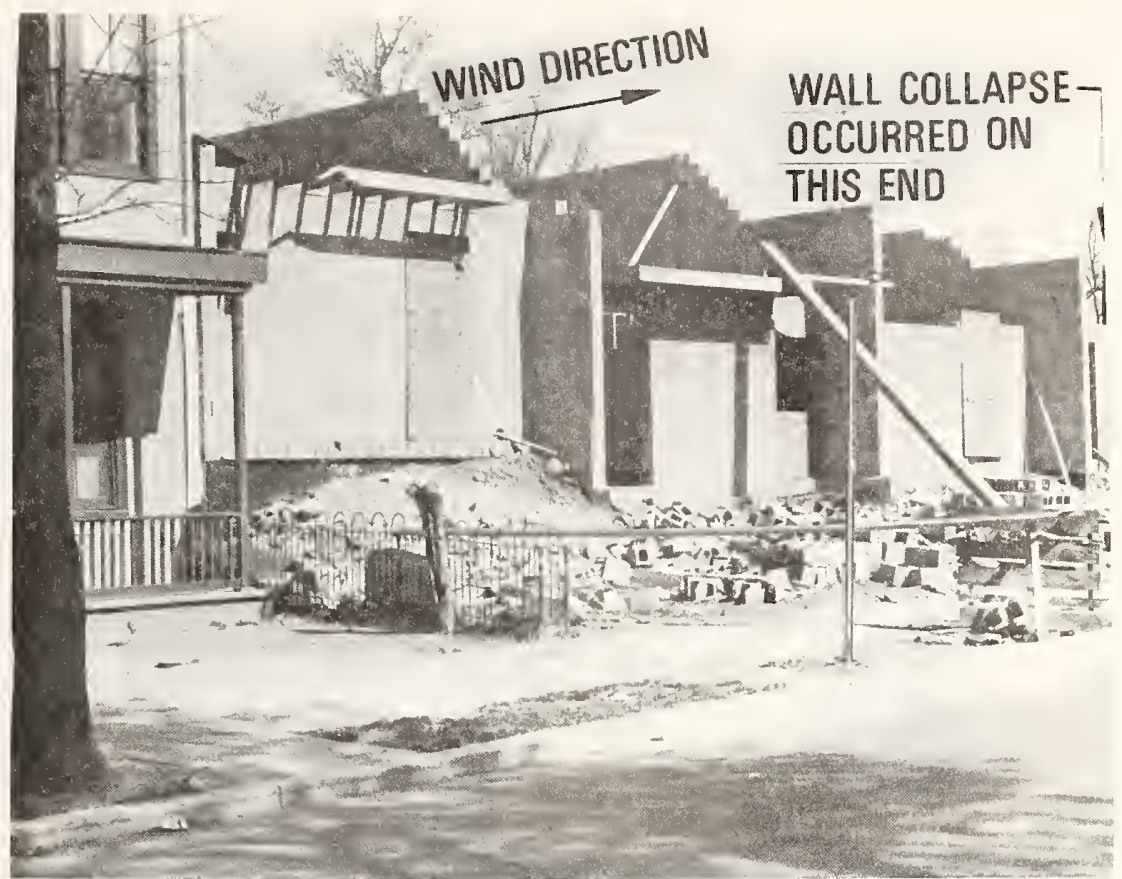

Figure 47 - Front elevation of three of the living units in row house complex.

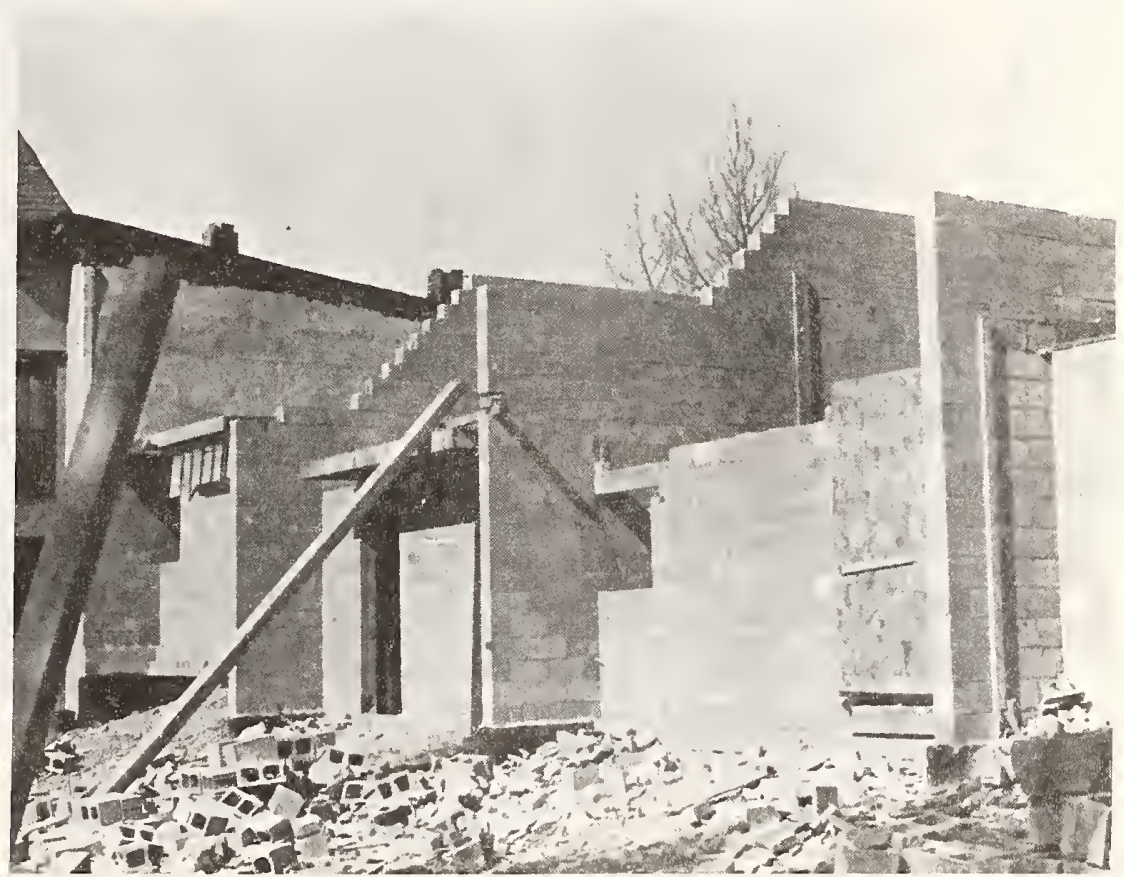

Figure 48 - Closeup front elevation of damaged masonry stmictures. 


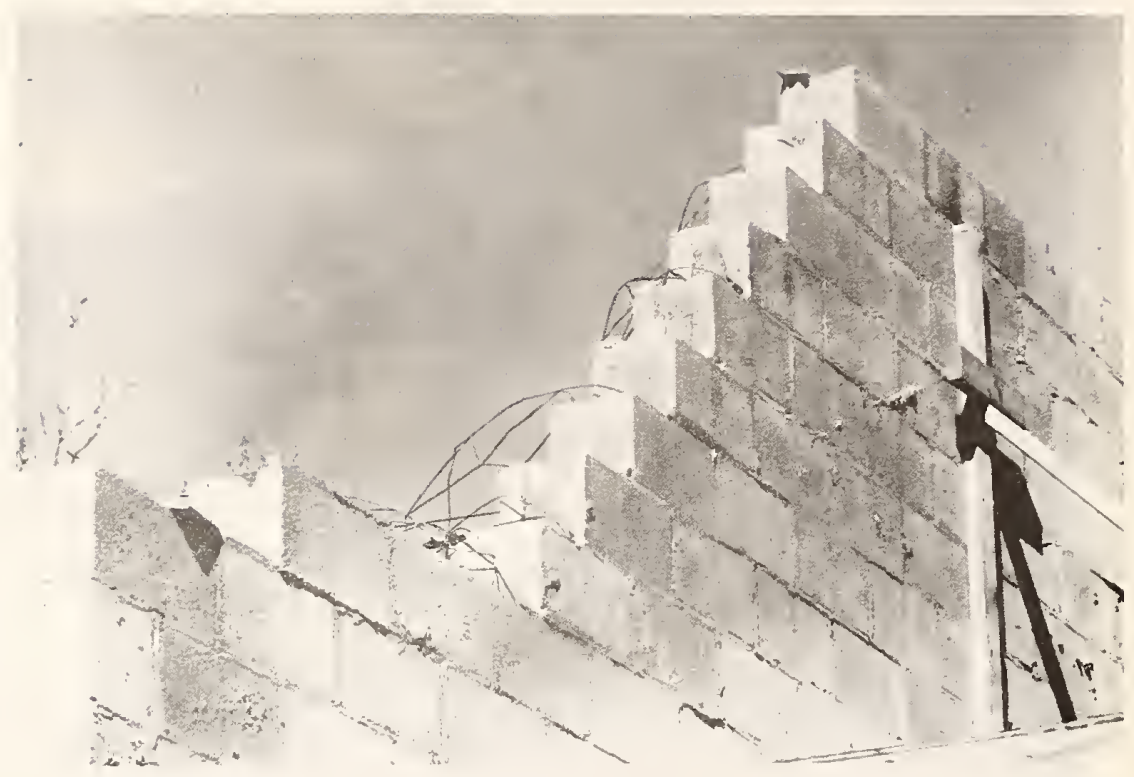

Figure 49 - Details of pulled-out joint reinforcement in a damaged cross wall.

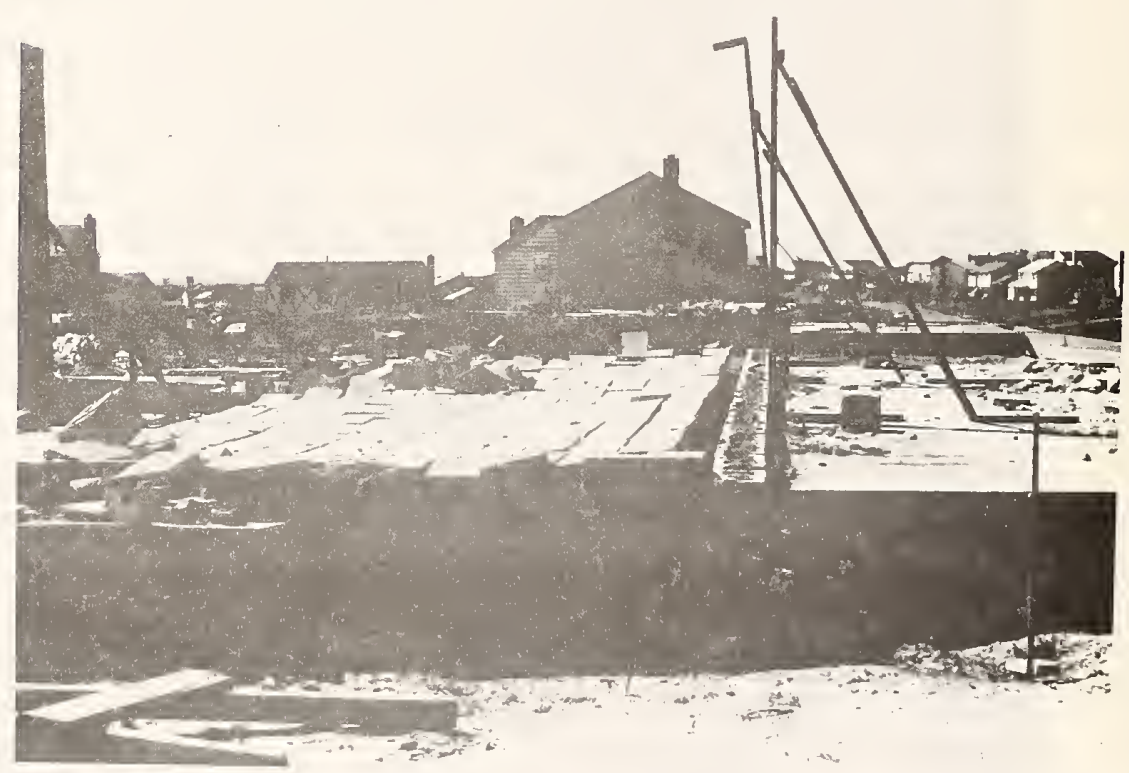

Eigure 50 - Masonry wazl failure during construction. 


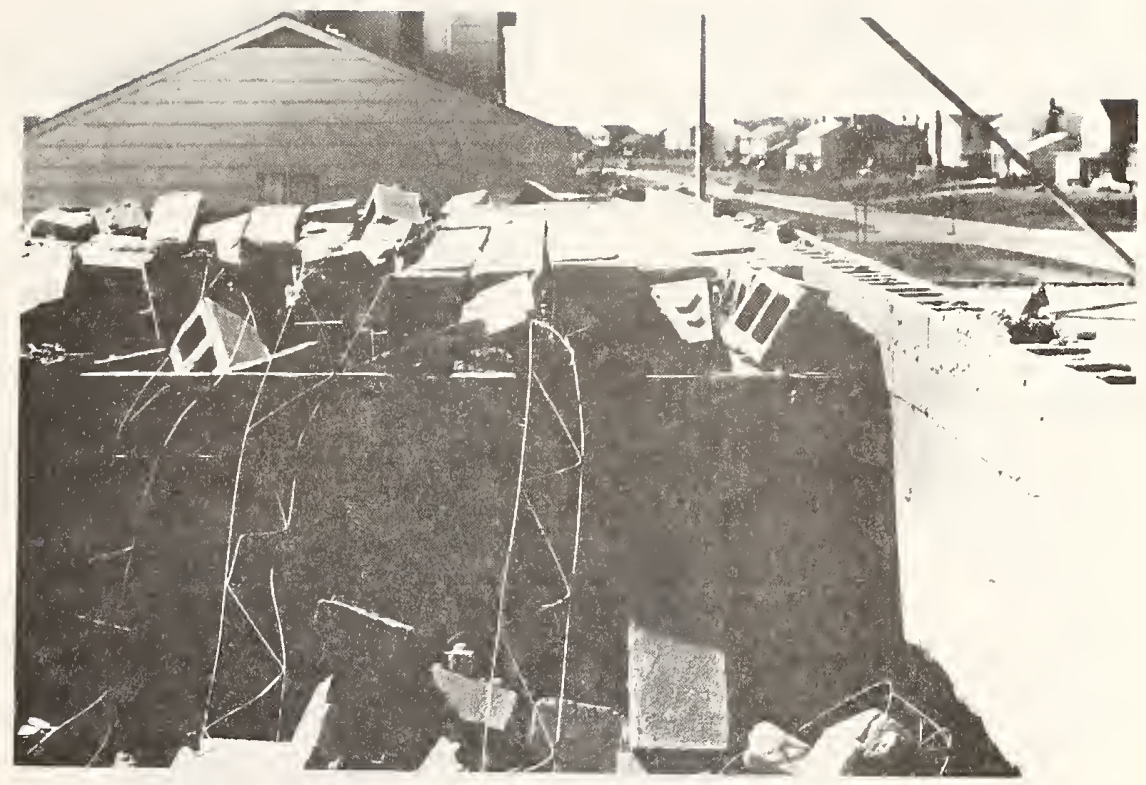

Figure 51 - Closeup view of collapsed wall showing horizontal joint reinforcement. 


\subsection{Miscellaneous Damage}

Figure 52 shows an approximately $40 \mathrm{ft}(12.2 \mathrm{~m})$ high church steeple which was observed to sway considerably. Figure 53 is a picture of the ceiling at the base of the church steeple. Note the damage that was caused to the cladding by the movement of the steeple. The brittle gypsum ceiling spalled as a result of the movement of the steel truss members .

Figure 54 is an overall view of a church which suffered considerable roof damage. Figures 55, 56 and 57 show more detail of the roof damage. Figure 58 shows gaps in the roof which were caused by uplift forces. Damage to the flashing is shown in figure 59. The roofing is rigid asbestos shingles.

The remaining figures show damage to buildings and structures to the north and west of Washington,D. C. where the wind speeds are believed to have been slightly higher then the NWS observations described in Section 2. Figures 60 and 61 show damage to asphalt shingle roofs in a subdivision. Damage to a barn roof is shown in figure 62. Damage to sheet metal siding in row-house units is shown in figures 63 and 64. Damage to signs and billboards is shown in figures 65 and 66. Figure 67 shows a severely damaged barn. 


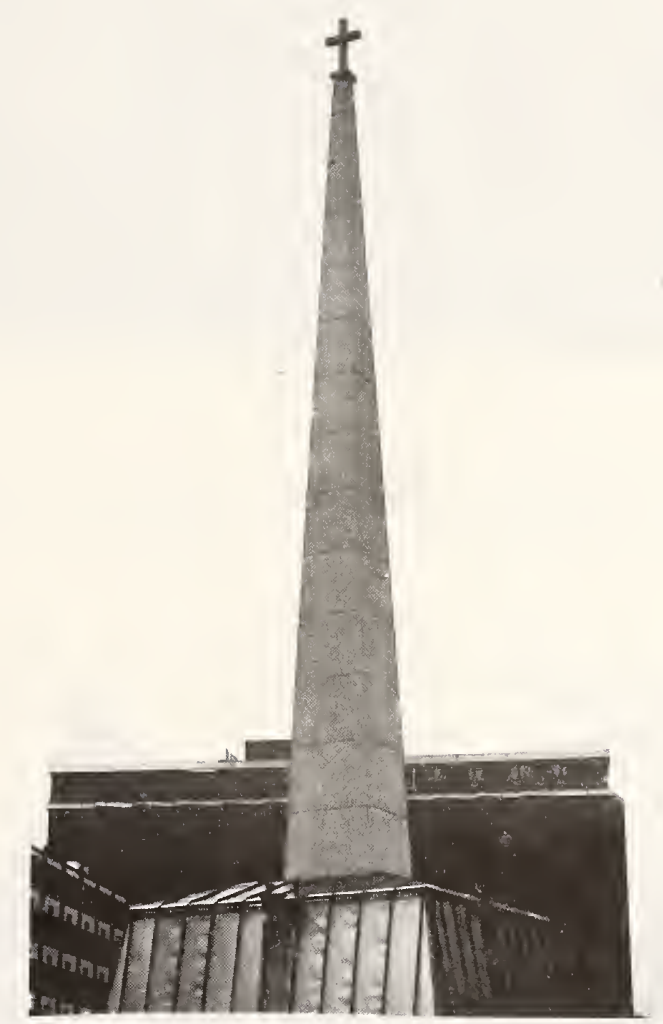

Figure 52 - Elevation of a church steeple affected by wind. 


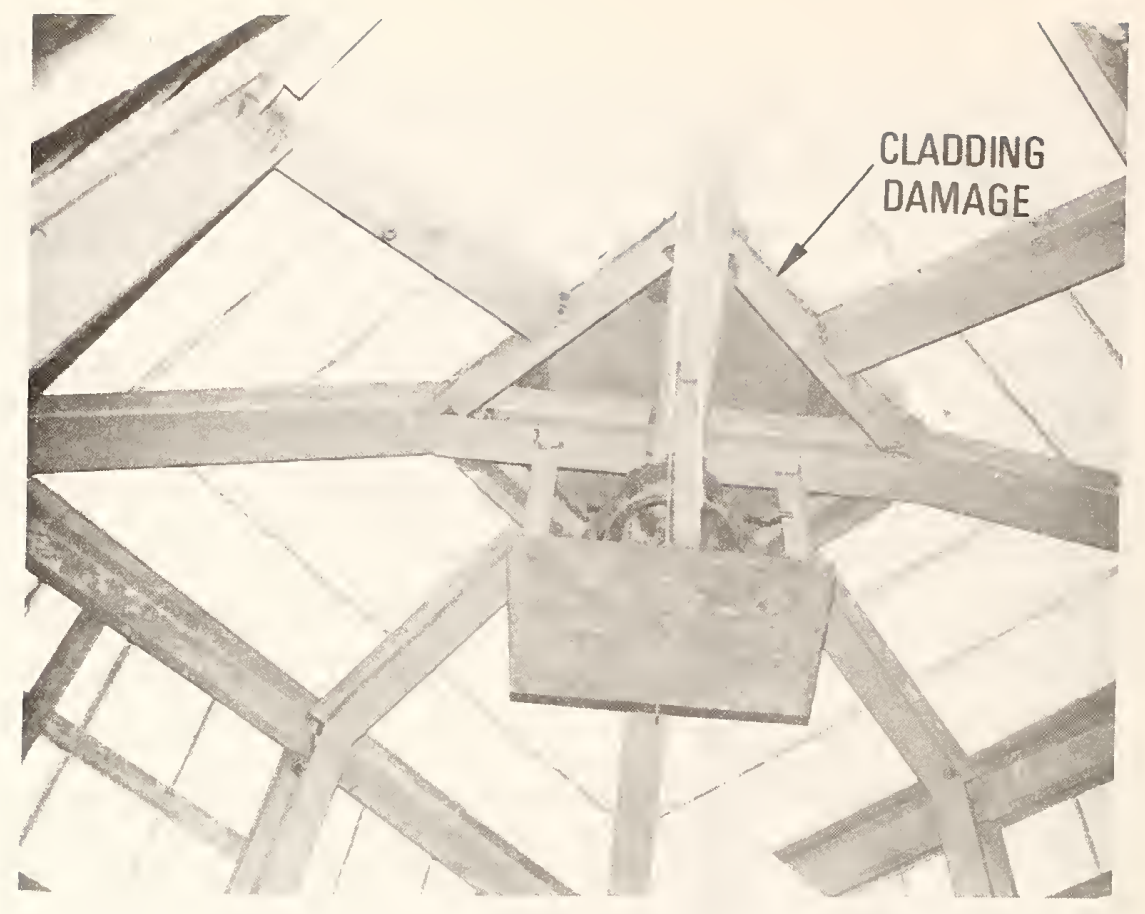

Figure 53 - Damaged ceiling cladding at the base of church steeple.

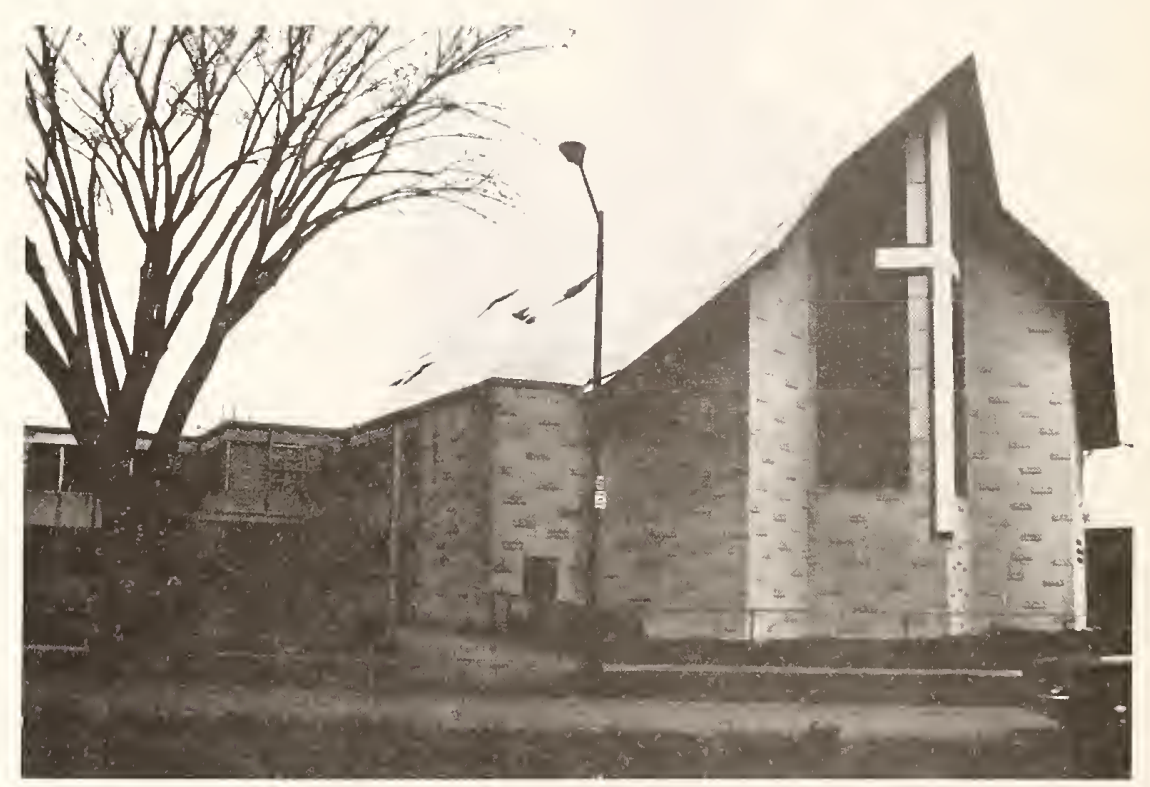

Figure 54 - overall view of a church which suffered roof damage. Looking west. 


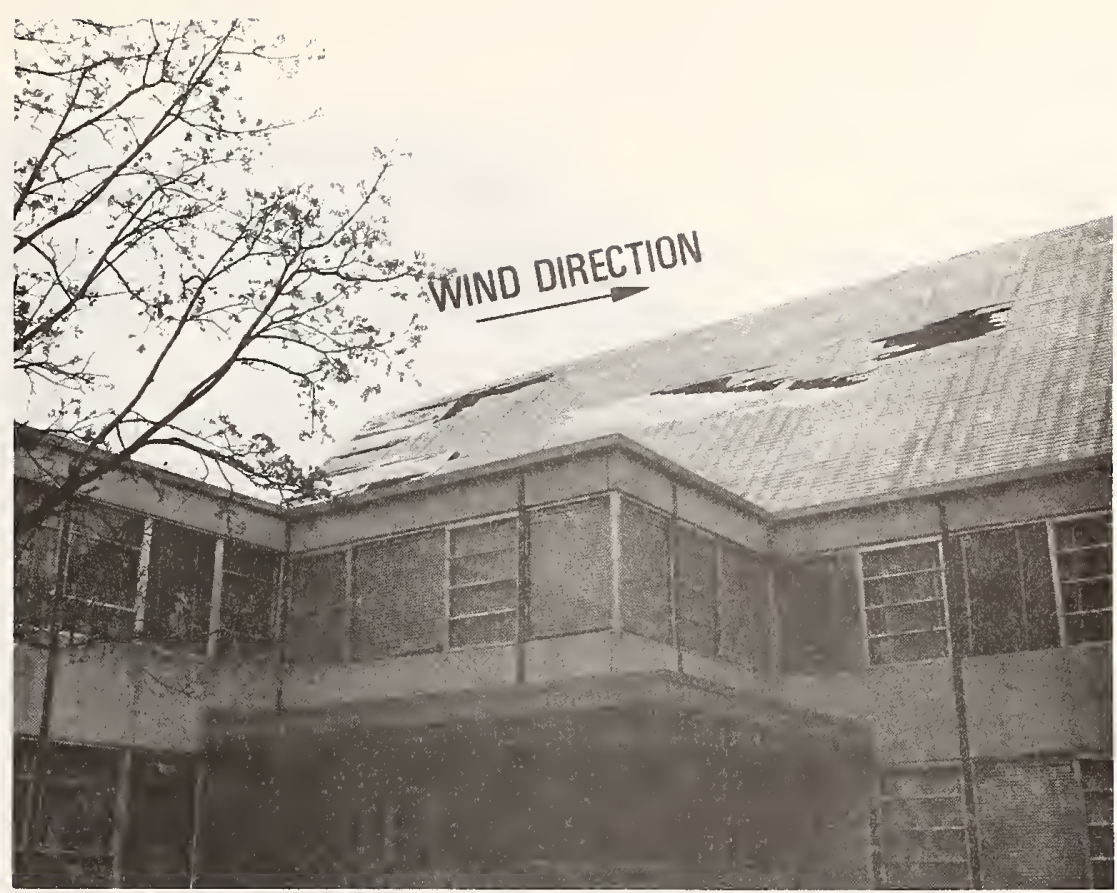

Figure 55 - View along church roof showing extent of roof damage. Looking north.

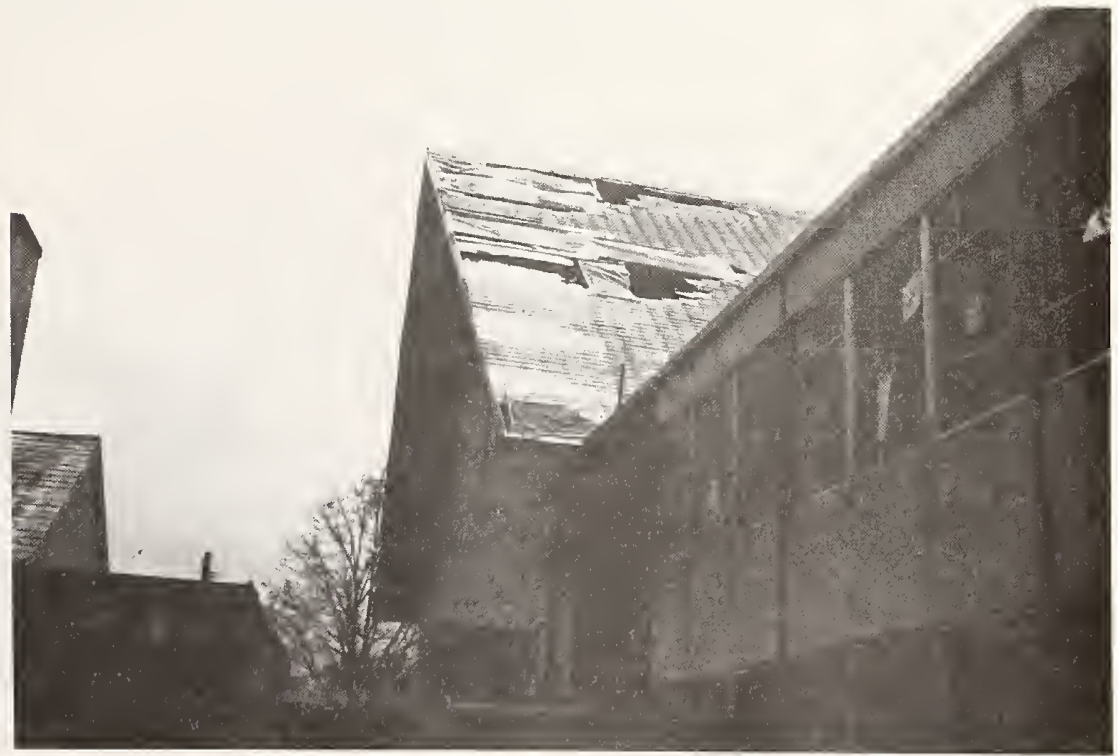

Figure 56 - Roof damage at rear (west side) of church. 


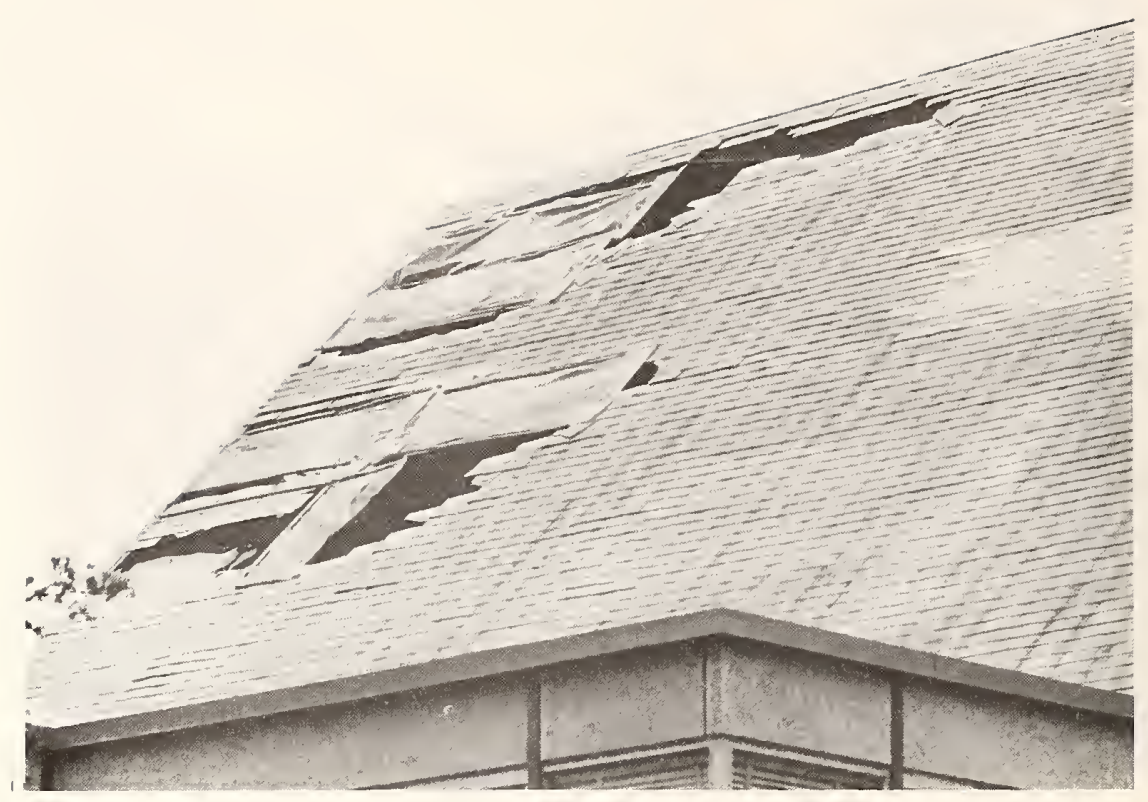

Eigure 57 - Closeup view of roof damage at rear of church.

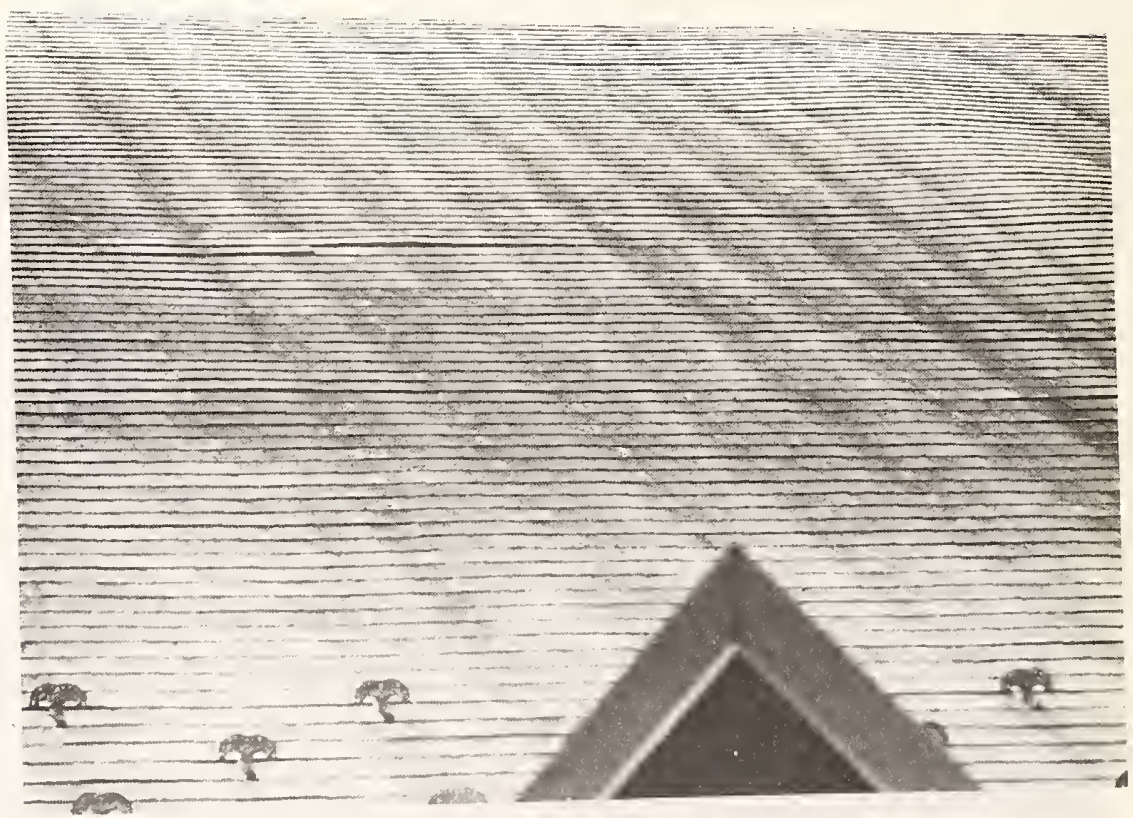

Eigure 58 - Uplift of asbestos roof shingles along north side of church. 


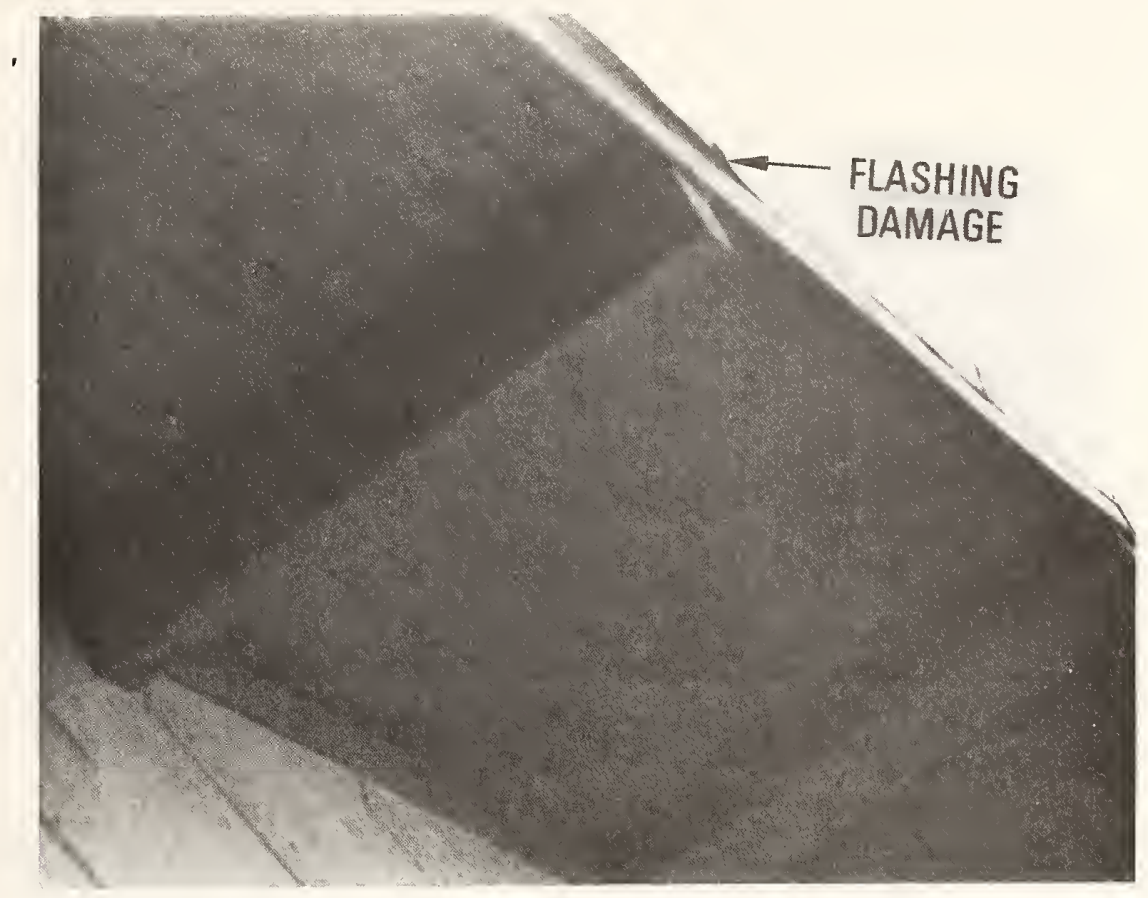

Figure 59 - Damage to roof flashing on gable overhang.

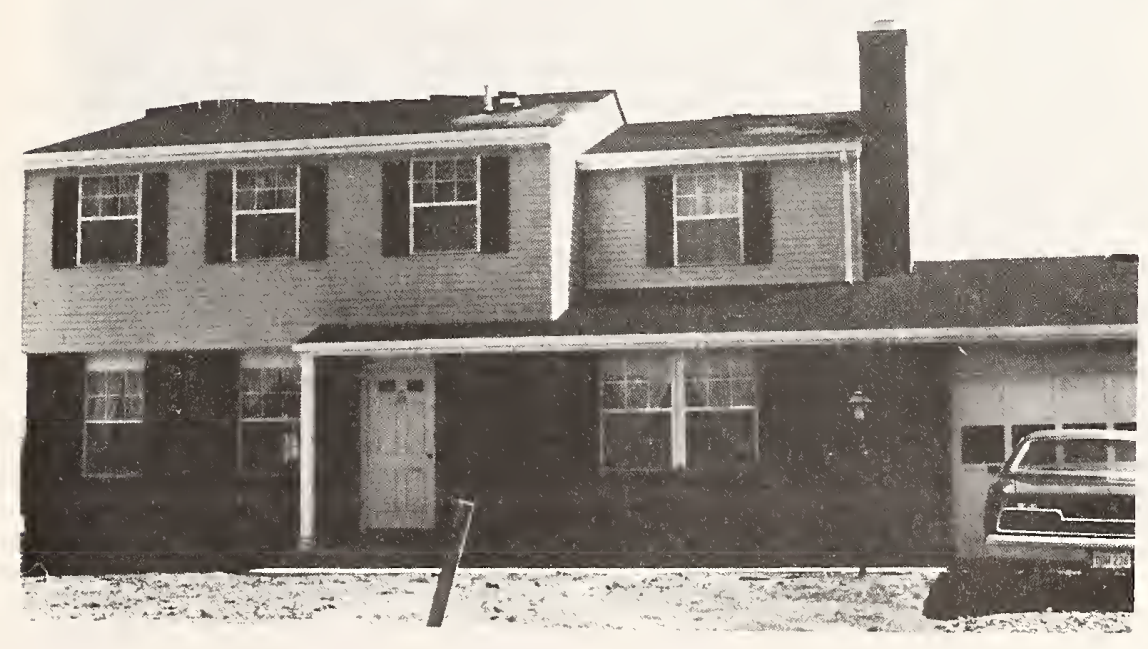

Figure 60 - Damage to asphalt shingle roof located in a new subdivision. 


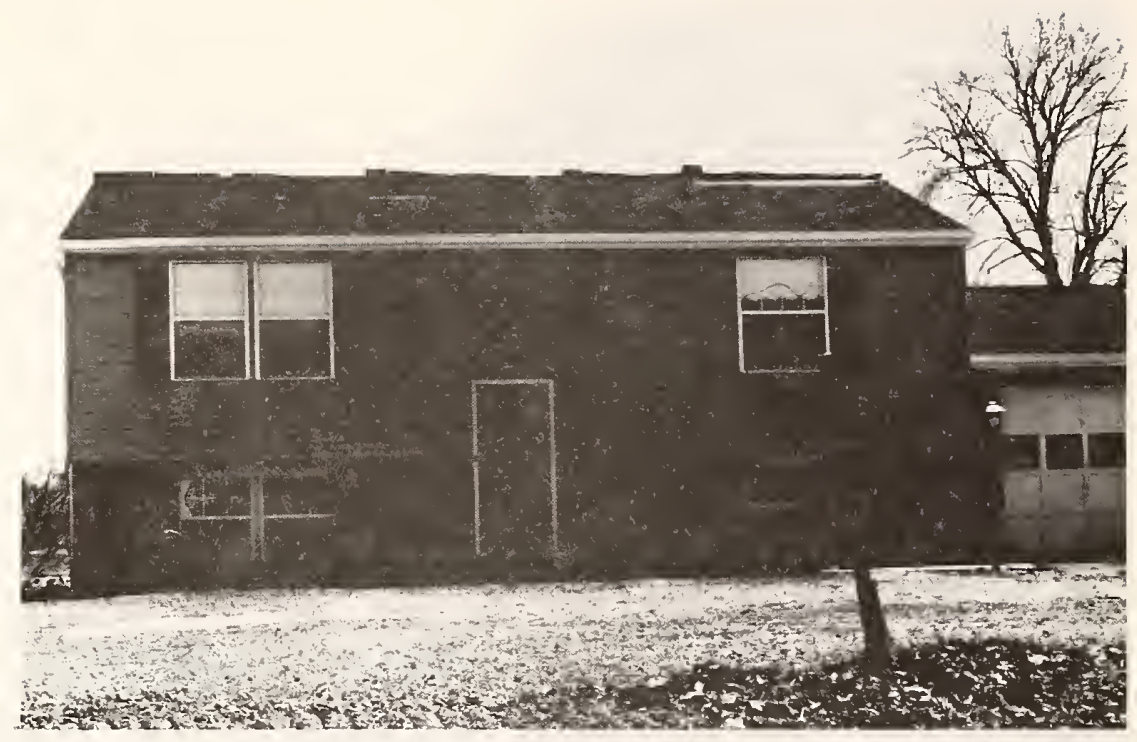

Figure 61 - Uplift of asphalt shingles along ridge and over other roof areas.

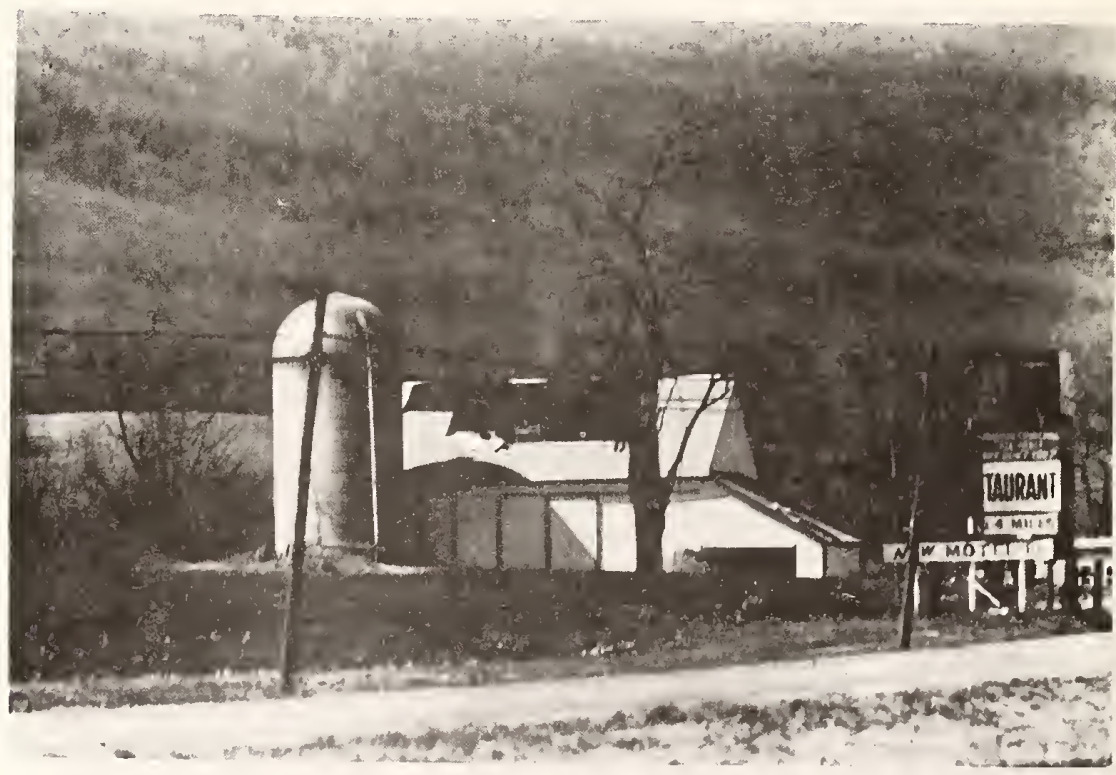

Figure 62 - Roof damage sustained by a barn located in an open area. 


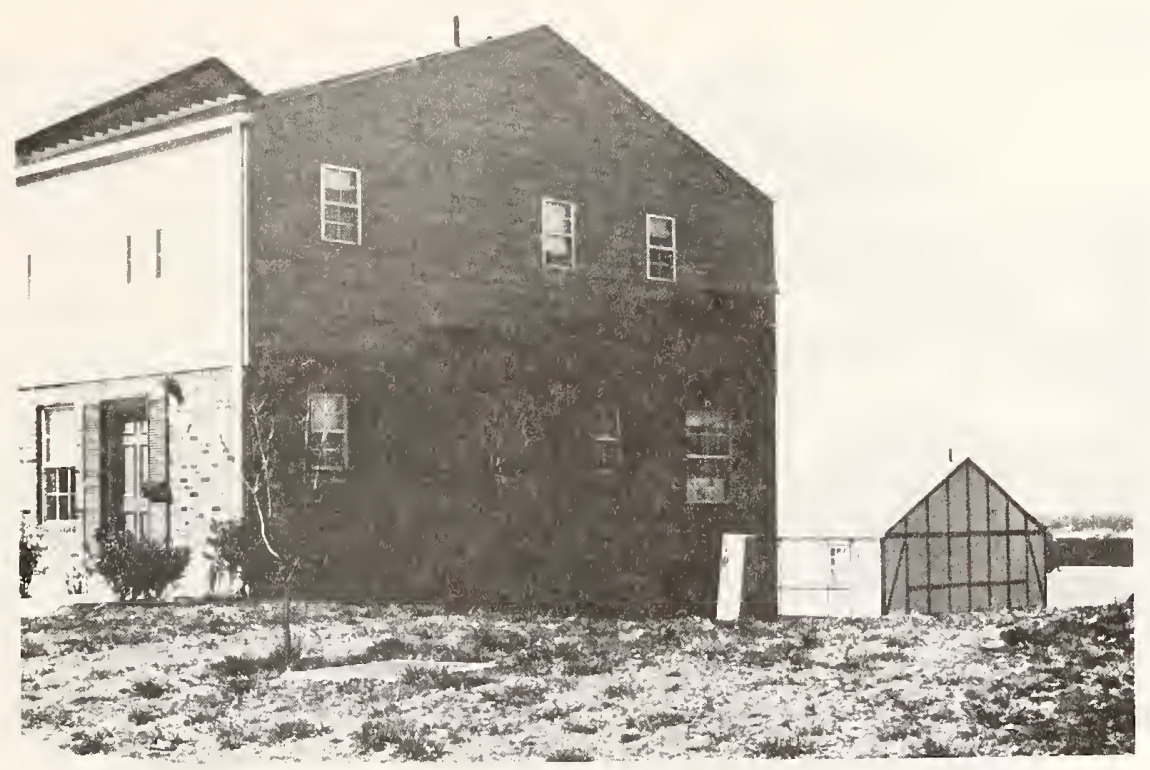

Figure 63 - Damaged sheet metal siding on an end townhouse unit.

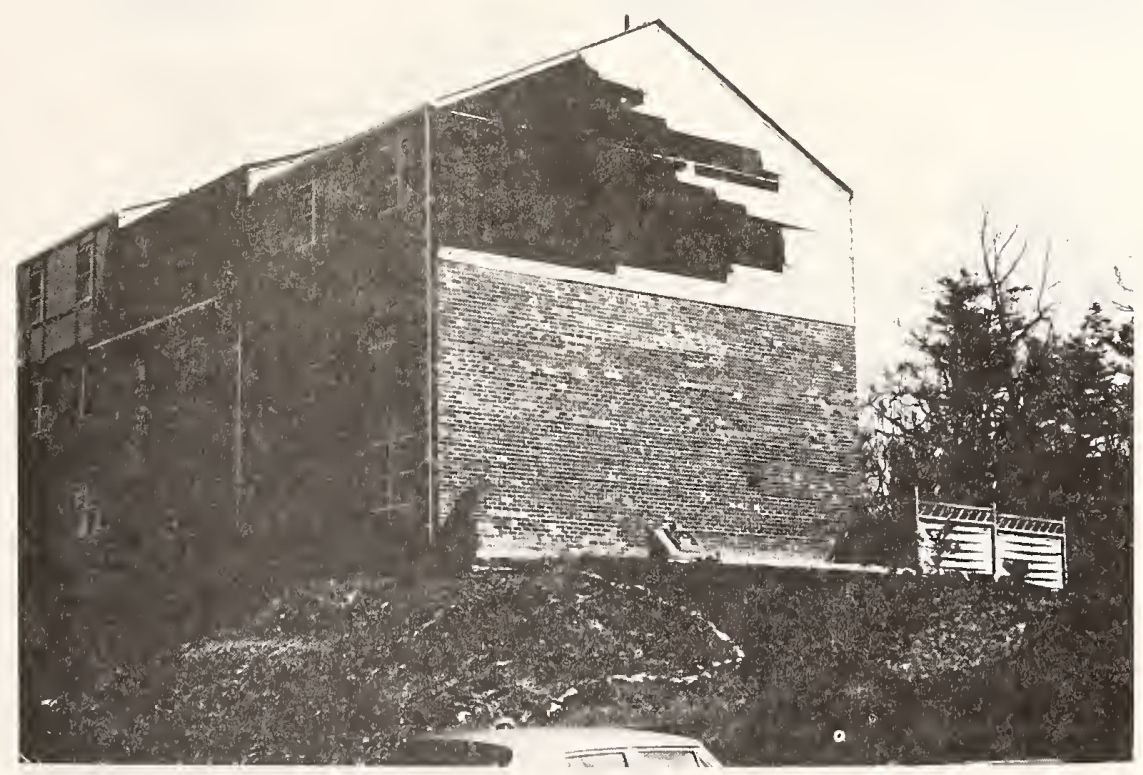

Figure 64 - Damaged sheet metal siding on a townhouse unit. 


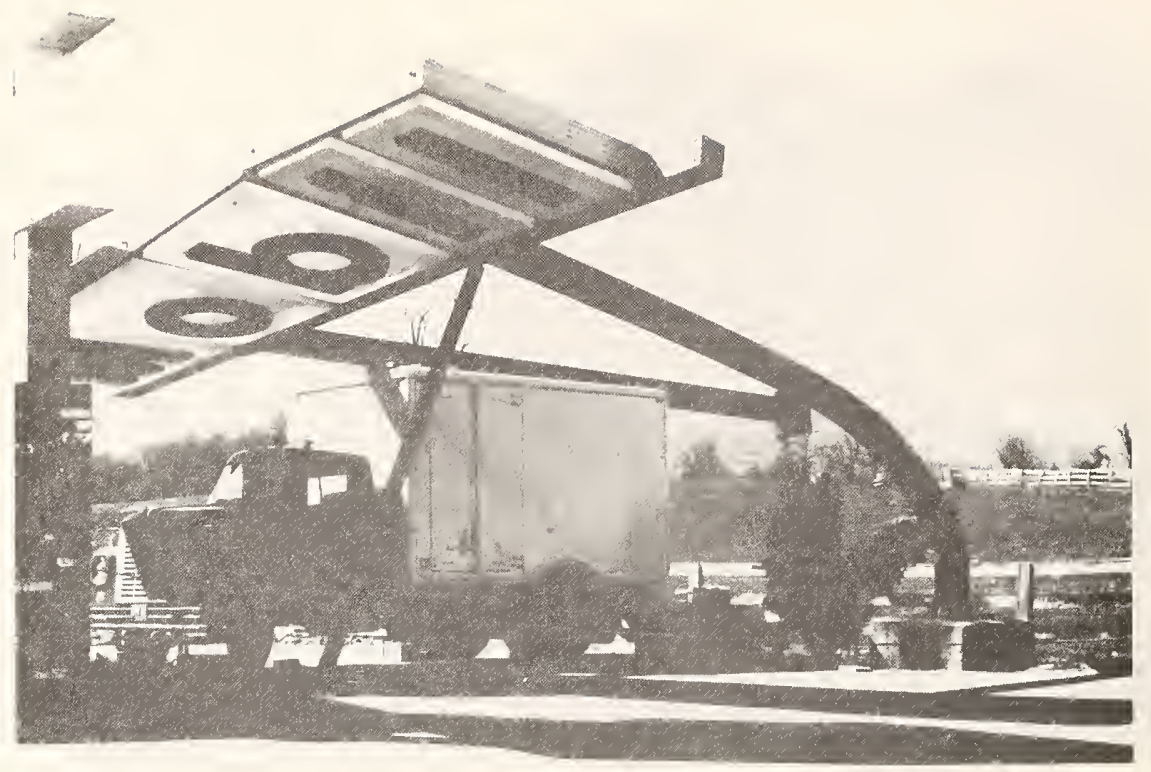

Figure 65 - Overturning failure of a service station sign.

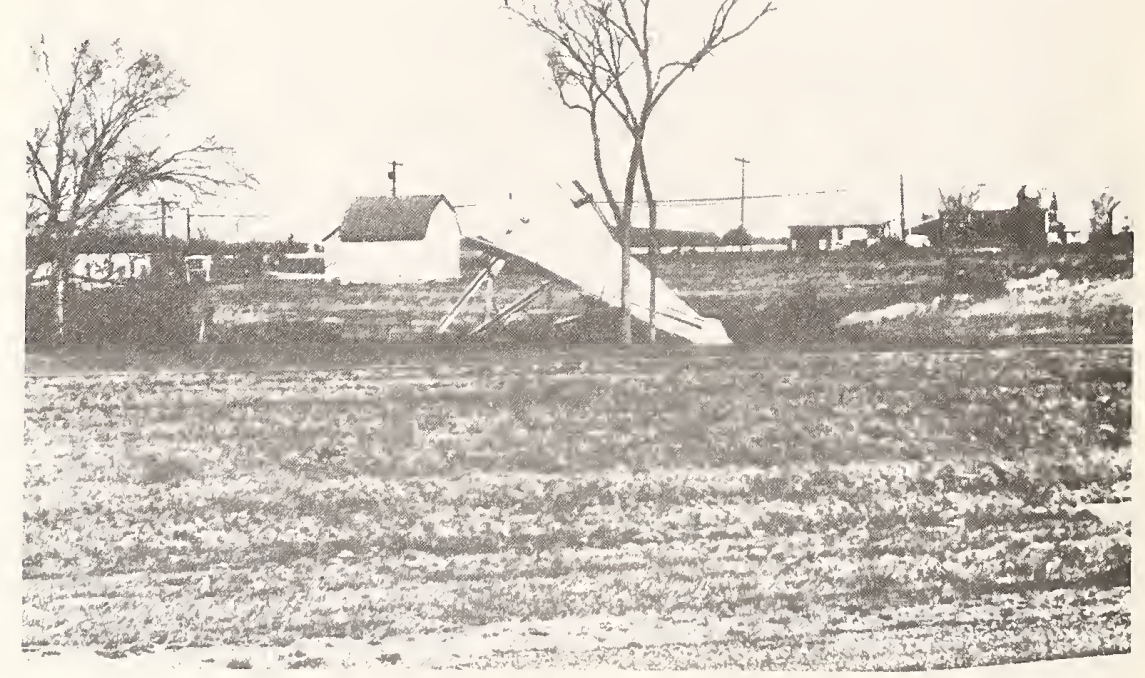

Figure 66 - overturning failure of a roadside billboard. 


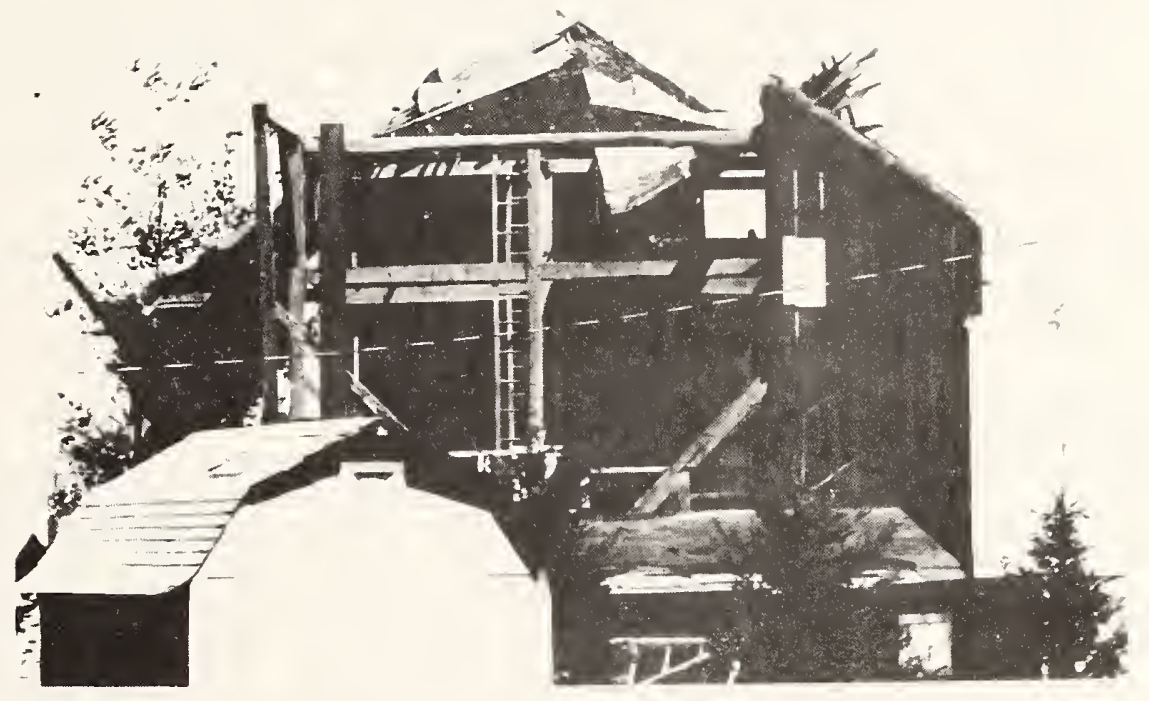

Figure 67 - Partial collapse of a barn located in rural area. 


\section{DISCUSSION OF FIELD OBSERVATIONS}

\subsection{General}

Based on available wind speed measurements, the winds causing the damage surveyed in this report had a mean recurrence interval of approximately 5 years. In accordance with prevailing design practice, residential buildings should be designed to resist dynamic pressures approximately 80 percent higher than those associated with the measured wind. Thus it is postulated that the observed damage reflects inadequacies in the design or construction, some of which may be attributable to deficiencies in building codes and design standards.

Hereafter is a brief discussion of the types of construction that suffered damage.

\subsection{Non-loadbearing Masonry Walls}

Within the range of loads which masonry walls are designed to support, their lateral-1oad capacity increases when the vertical load they support is increased. Thus a wall which supports heavy vertical loads is much less vulnerable to wind load than is a non-loadbearing wall. This important fact should be recognized by designers and reflected in building codes and design standards. Even though other structural members do not depend on nonloadbearing masonry walls for their support, the collapse of such walls, because of the weight of the debris, is a serious safety hazard and the impact loads from falling debris may trigger further structural collapse. This is illustrated in the case reported in Section 4.1.

To be structurally safe, non-loadbearing masonry walls must be capable of resisting wind-induced moments without depending on the strengthening effect of vertical loads transferred from other members.

The absence of substantial vertical loads also reduces the lateralload capacity of connections, since no restraint can be derived from frictional resistance. Thus it is critically important to provide adequate ties to intersecting structural elements. A wall panel which is inadequately tied at its top becomes a cantilever wall with a corresponding reduction in lateral-load capacity. 
The preceding discussion which generally applies to all types of non-loadbearing walls is applicable to some of the following cases which were encountered in this survey:

(a) Curtain walls

Curtain walls are continuous over more than one story and can be very vulnerable if the connections to the structure are inadequate. In the case in Section 4.1 no evidence was found of ties between the curtain wall and the roof, or any of the floor diaphragms. Since in this case only the 4 in $(10 \mathrm{~cm})$ thick block wythe was supported at each floor level, the only connection to the building was provided by the mortar joints between the block wythe and the concrete slabs. The resistance to wall separation, provided by these joints, would depend on the bond strength of the mortar and on frictional forces. As previously noted, frictional forces are very small in non-loadbearing walls, and the bond strength of the mortar can not be relied on, since, in many cases, separation may occur by shrinkage of the block wythe, expansion of the bxick wythe, or volume changes and bending induced by temperature gradients. In absence of an effective connection, any part of the $70 \mathrm{ft}(21.3 \mathrm{~m})$ high curtain wall described in Section 4.1 could separate from the structure under extreme loading conditions. In this particular instance the upper-story portion acted as a cantilever. Both, adequate ties to the structure and adequate strength of the wall to resist the horizontal load without the assistance of a verticalload component are necessary to prevent such a failure.

(b) Gable Walls

The upper portions of gable walls become free-standing cantilevers when their connection to the roof fails. The upper portion of these walls does not support any substantial vertical load, and may even be subjected to a net upward tensile force if substantial uplift acts on the roof. Thus the lateral-load capacity of this portion of the gable wall is small. In the case presented in section 4.3 the joint between the gable wall and the roof failed as a result of the uplift force on the roof and subsequently the wall could not resist the wind force. 
(c) Masonry Veneer

Masonry veneer derives most of its lateral-load resistance from horizontal ties to structural members. Its tolerance to horizontal deflections is small when compared to other types of exterior skin. Thus, the horizontal ties to the structure must have adequate strength to transmit the wind load (pressure or suction), and have adequate stiffness to prevent excessive deflection of the veneer. Even though this was not definitely proven the evidence in the case presented in Section 4.2 seems to indicate that the primary cause of failure was excessive slack in the ties, which can be viewed as a form of "inadequate stiffness."

\subsection{Overhanging Roofs}

Overhanging portions of roofs are subjected to greater net uplift forces than other parts of the roof and thus are vulnerable to wind damage. The observed instances (Sections 4.2, 4.3, and 4.5) illustrate several aspects of the problem:

(a) Major structural failure may be triggered when the wall depends on lateral support from the roof (Section 4.3).

(b) The force exerted on the overhanging portion of the roof may also trigger failure in other portions of the roof (Section 4.5). The most frequently observed failure mechanism is initial failure of connections between various portions of the roof construction, such as nailing of the sheathing and roofing to the purlins, the connection between purlins and trusses, or the connection of the roof structure as a whole to the building. These initial connection failures subsequently trigger failure of the connected elements. Most roof failures have a tendency to propagate because of leverage exerted by partially disconnected elements.

\subsection{Unusual Building Configurations}

The geometric configuration of a structure or the effect of adjacent structures may cause responses of unanticipated severity. In the following instances this may have been the case: 
(a) The configuration of the twin apartment towers with the narrow passage between the two buildings may have played some role in the failure reported in Section 4.1.

(b) The dynamic response of the masonry infill wall in Section 4.4 may have been caused by turbulence induced by the building configuration since this type of construction would normally not have experienced distress under the reported wind conditions.

(c) The church steeple of Section 4.8 apparently experienced displacements in excess of those anticipated in the design.

\subsection{Structural Skin (cladding and roofing)}

Section 4 documents several cases of separation of structural skin, mostly on roofs, but in some instances on sidewalls. The prevalence of roof damage was generally attributable to the suction acting along the leading edges of roofs. No attempt was made to determine whether damage in any particular case was attributable to construction or design defects. In any case, the great number of instances observed suggests that present practice with respect to the attachment of structural skin may be inadequate in locations where high local suction can be expected.

\subsection{Buildings under Construction}

At various stages of construction, buildings are vulnerable to wind damage. It would not be reasonable to require that a building under construction be able to resist the design wind load which has a 50-year mean recurrence interval. However, the wind reported herein, which had an estimated 5-year mean recurrence interval; should not have caused hazardous failures in buildings under construction. The failures discussed hereafter are hazardous to workmen, bystanders, and adjacent property.

(a) Masonry walls under construction:

At various construction stages masonry walls are free standing cantilevers. Their vulnerability to wind pressures is further increased by the uncured mortar which did not achieve its full tensile strength. Because of the great weight of the debris, the collapse of such walls 
endangers human life and adjacent property, and may even trigger progressive structural collapse of large portions of a building. Thus adequate bracing should be in place during all the construction stages. Two instances of masonry wall collapse are reported in section 4.7.

(b) Roofs under construction:

Roofs may be vulnerable for the following reasons:

1. If roofing is only partially installed the roof may be subjected to the full uplift forces while part of the weight counted on to resist this force is not yet in place;

2. If windows or cladding are only partially completed the temporary position of openings may give rise to internal wind pressures in excess of those assumed in the design. These pressures, combined with suction forces acting on the roof, may cause overall roof failure.

3. Connections may be unfinished or their grouting may be insufficiently cured.

Roof failures could endanger human lives and missile effects associated with such failures could cause secondary damage. Some or all of the conditions previously discussed may have contributed to the roof failure reported in Section 4.6 .

\section{SUMMARY AND RECOMMENDATIONS}

Available meteorological data indicate that the high winds associated with the damage reported herein were less severe than those that should be anticipated by designers. Thus most of the observed damage is probably attributable to deficiencies in design, construction, or materials. Even though the instances of damage observed represent only a small percentage of the total inventory of building structures in the affected area, the nature of the damage and its probable causes raise serious questions about the adequacy of some aspects of present design and construction practice.

The following types of construction were found to be vulnerable to wind damage: non-loadbearing masonry walls, including curtain walls, veneer, and the upper portion of gable walls; overhanging roofs; some 
unusual building configurations; exterior skin; and masonry walls and roofs under construction.

It is recommended that building codes, design standards, FHA minimum property standards, and conventional construction practice be reviewed by appropriate standard-writing bodies or professional committees in order to determine their adequacy in the following areas:

- Connections for curtain walls and masonry veneer

- Connections between gable walls and roofs

- Roof construction with particular emphasis on overhangs and connections between the various elements.

- Attachment of siding and roofing

- Temporary bracing of masonry walls during construction

- Precautions against roof failures during construction

- Design requirements and guides for unusual building configurations.

\section{ACKNOWLEDGEMENTS}

The meteorological data were provided by the National Climatic Center of the Environmental Data service of the National Oceanic and Atmospheric Administration.

The following persons provided assistance in the collection of information which forms the basis of this report:

Prince George's County, Maryland

James R. Novak, Chief Building Inspector

David S. Robinson, Deputy Chief Building Inspector

Joseph B. McKay, Building Inspector

District of Columbia

Francis C. Boarman, Acting Chief, Construction Section, Inspection Division

Arlington County, Virginia

P. 0. Shepherd, Jr., Director of Inspections

Richard B. Bier, Asst. Director of Inspections

Edward V. Bethel, Chief, Building Inspections Division

Alexandria, Virginia

Charles 0. Eberly, Director, Mechanical and Building Inspections Dalton Getz, Field Building Inspector 
The authors are also indebted to Betram M. Vogel from the Center for Building Technology, for information on the building regulatory system in the Washington D. C., Metropolitan area.

\section{REFERENCES}

[1] American National Standard Institute A58.1-1972, Building Code Requirements for Minimum Design Loads on Buildings and Other Structures, New York, N. Y. 10018. 


\section{NBS TECHNICAL PUBLICATIONS}

\section{PERIODICALS}

JOURNAL OF RESEARCH reports National Bureau of Standards research and development in physics, mathematics, and chemistry. It is published in two sections, available separately:

\section{- Physics and Chemistry (Section A)}

Papers of interest primarily to scientists working in these fields. This section covers a broad range of physical and chemical research, with major emphasis on standards of physical measurement, fundamental constants, and properties of matter. Issued six times a year. Annual subscription: Domestic, \$17.00; Foreign, $\$ 21.25$.

\section{- Mathematical Sciences (Section B)}

Studies and compilations designed mainly for the mathematician and theoretical physicist. Topics in mathematical statistics, theory of experiment design, numerical analysis, theoretical physics and chemistry, logical design and programming of computers and computer systems. Short numerical tables. Issued quarterly. Annual subscription: Domestic, $\$ 9.00$; Foreign, $\$ 11.25$.

DIMENSIONS/NBS (formerly Technical News Bulletin)-This monthly magazine is published to inform scientists, engineers, businessmen, industry, teachers, students, and consumers of the latest advances in science and technology, with primary emphasis on the work at NBS. The magazine highlights and reviews such issues as energy research, fire protection, building technology, metric conversion, pollution abatement, health and safety, and consumer product performance. In addition, it reports the results of Bureau programs in measurement standards and techniques, properties of matter and materials, engineering standards and services, instrumentation, and automatic data processing.

Annual subscription: Domestic, $\$ 9.45$; Foreign, $\$ 11.85$.

\section{NONPERIODICALS}

Monographs-Major contributions to the technical literature on various subjects related to the Bureau's scientific and technical activities.

Handbooks-Recommended codes of engineering and industrial practice (including safety codes) developed in cooperation with interested industries, professional organizations, and regulatory bodies.

Special Publications-Include proceedings of conferences sponsored by NBS, NBS annual reports, and other special publications appropriate to this grouping such as wall charts, pocket cards, and bibliographies.

Applied Mathematics Series-Mathematical tables, manuals, and studies of special interest to physicists, engineers, chemists, biologists, mathematicians, computer programmers, and others engaged in scientific and technical work.

National Standard Reference Data Series-Provides quantitative data on the physical and chemical properties of materials, compiled from the world's literature and critically evaluated. Developed under a world-wide program coordinated by NBS. Program under authority of National Standard Data Act (Public Law 90-396).

NOTE: At present the principal publication outlet for these data is the Journal of Physical and Chemical Reference Data (JPCRD) published quarterly for NBS by the American Chemical Society (ACS) and the American Institute of Physics (AIP). Subscriptions, reprints, and supplements available from ACS, 1155 Sixteenth St. N. W., Wash. D. C. 20056.

Building Science Series-Disseminates technical information developed at the Bureau on building materials, components, systems, and whole structures. The series presents research results, test methods, and performance criteria related to the structural and environmental functions and the durability and safety characteristics of building elements and systems.

Technical Notes-Studies or reports which are complete in themselves but restrictive in their treatment of a subject. Analogous to monographs but not so comprehensive in scope or definitive in treatment of the subject area. Often serve as a vehicle for final reports of work performed at NBS under the sponsorship of other government agencies.

Voluntary Product Standards-Developed under procedures published by the Department of Commerce in Part 10, Title 15, of the Code of Federal Regulations. The purpose of the standards is to establish nationally recognized requirements for products, and to provide all concerned interests with a basis for common understanding of the characteristics of the products. NBS administers this program as a supplement to the activities of the private sector standardizing organizations.

Federal Information Processing Standards Publications (FIPS PUBS)-Publications in this series collectively constitute the Federal Information Processing Standards Register. Register serves as the official source of information in the Federal Government regarding standards issued by NBS pursuant to the Federal Property and Administrative Services Act of 1949 as amended, Public Law 89-306 (79 Stat. 1127), and as implemented by Executive Order 11717 (38 FR 12315, dated May 11, 1973) and Part 6 of Title 15 CFR (Code of Federal Regulations).

Consumer Information Series-Practical information, based on NBS research and experience, covering areas of interest to the consumer. Easily understandable language and illustrations provide useful background knowledge for shopping in today's technological marketplace.

NBS Interagency Reports (NBSIR)-A special series of interim or final reports on work performed by NBS for outside sponsors (both government and non-government). In general, initial distribution is handled by the sponsor; public distribution is by the National Technical Information Service (Springfield, Va. 22161) in paper copy or microfiche form.

Order NBS publications (except NBSIR's and Bibliographic Subscription Services) from: Superintendent of Documents, Government Printing Office, Washington, D.C. 20402 .

\section{BIBLIOGRAPHIC SUBSCRIPTION SERVICES}

The following current-awareness and literature-survey bibliographies are issued periodically by the Bureau:

Cryogenic Data Center Current Awareness Service

A literature survey issued biweekly. Annual subscription: Domestic, $\$ 20.00$; foreign, $\$ 25.00$.

Liquefied Natural Gas. A literature survey issued quarterly. Annual subscription: $\$ 20.00$.

Superconducting Devices and Materials. A literature
Survey issued quarterly. Annual subscription: $\$ 20.00$. Send subscription orders and remittances for the preceding bibliographic services to National $\mathrm{Bu}-$ reau of Standards, Cryogenic Data Center (275.02) Boulder, Colorado 80302 .

Electromagnetic Metrology Current Awareness Service Issued monthly. Annual subscription: $\$ 24.00$. Send subscription order and remittance to Electromagnetics Division, National Bureau of Standards, Boulder, Colo. 80302 . 
U.5. DEPARTMENT OF COMMERCE

National Bureau of Standards

Washington. D.C. 20234

POSTAGE AND FEES PAID

OFFICIAL BUSINESS

U.S. DEPARTMENT OF COMMERCE COM-215

Penalty for Private Use. $\$ 300$

SPECIAL FOURTH-CLASS RATE BOOK 